U.S. Department of the Interior

U.S. Geological Survey

\title{
Catalog of Earthquake Hypocenters at Alaskan Volcanoes: January 1 through December 31, 2002
}

By James P. Dixon ${ }^{1}$, Scott D. Stihler², John A. Power ${ }^{3}$, Guy Tytgat ${ }^{2}$, Seth C. Moran ${ }^{3}$, John Sánchez ${ }^{2}$, Steve Estes ${ }^{2}$, Stephen R. McNutt ${ }^{2}$, and John Paskievitch ${ }^{3}$.

U.S. Geological Survey Open-File Report 03-267

This report is preliminary and has not been reviewed for conformity with U.S. Geological Survey editorial standards. Any use of trade, product, or firm names is for descriptive purposes only and does not imply endorsement by the U. S. Government.

\footnotetext{
${ }^{1}$ Alaska Volcano Observatory, U. S. Geological Survey, 903 Koyukuk Drive, Fairbanks, Alaska 99775

${ }^{2}$ Alaska Volcano Observatory, Geophysical Institute, 903 Koyukuk Drive, Fairbanks, Alaska 99775

${ }^{3}$ Alaska Volcano Observatory, U. S. Geological Survey, 4200 University Drive, Anchorage, Alaska 99508
} 


\section{TABLE OF CONTENTS}

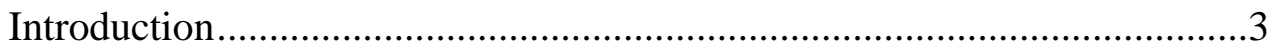

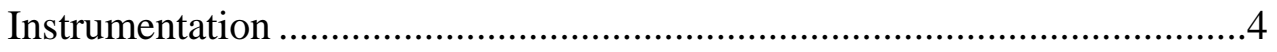

Data Acquisition and Reduction ......................................................6

Velocity Models...............................................................................8

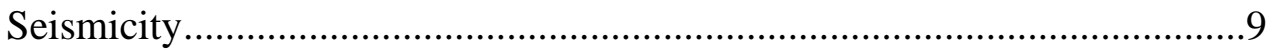

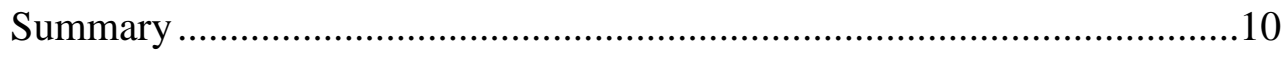

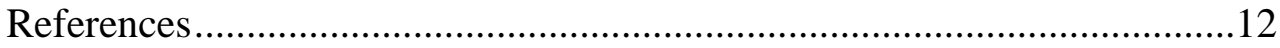

Appendix A: Maps of the earthquakes located in 2002 ............................14

Appendix B: Parameters for all AVO seismic stations.............................36

Appendix C: Maps of permanent AVO seismic stations ..........................40

Appendix D: Velocity models .......................................................51

Appendix E: Maps showing volcanic zones modeled using cylinders .......54

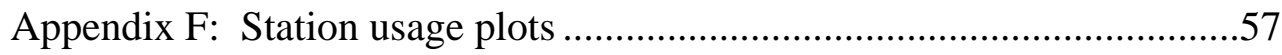

Appendix G: Selected AVO papers published in 2002 .............................58 


\section{Introduction}

The Alaska Volcano Observatory (AVO), a cooperative program of the U.S. Geological Survey, the Geophysical Institute of the University of Alaska Fairbanks, and the Alaska Division of Geological and Geophysical Surveys, has maintained seismic monitoring networks at historically active volcanoes in Alaska since 1988 (Power and others, 1993; Jolly and others, 1996; Jolly and others, 2001; Dixon and others, 2002). The primary objectives of this program are the seismic monitoring of active, potentially hazardous, Alaskan volcanoes and the investigation of seismic processes associated with active volcanism. This catalog presents the basic seismic data and changes in the seismic monitoring program for the period January 1, 2002 through December 31, 2002.

Appendix $\mathrm{G}$ contains a list of publications pertaining to seismicity of Alaskan volcanoes based on these and previously recorded data.

The AVO seismic network was used to monitor twenty-four volcanoes in real time in 2002. These include Mount Wrangell, Mount Spurr, Redoubt Volcano, Iliamna Volcano, Augustine Volcano, Katmai Volcanic Group (Snowy Mountain, Mount Griggs, Mount Katmai, Novarupta, Trident Volcano, Mount Mageik, Mount Martin), Aniakchak Crater, Mount Veniaminof, Pavlof Volcano, Mount Dutton, Isanotski Peaks, Shishaldin Volcano, Fisher Caldera, Westdahl Peak, Akutan Peak, Makushin Volcano, Great Sitkin Volcano, and Kanaga Volcano (Figure 1). Monitoring highlights in 2002 include an earthquake swarm at Great Sitkin Volcano in May-June; an earthquake swarm near Snowy Mountain in July-September; low frequency $(1-3 \mathrm{~Hz})$ tremor and long-period events at Mount Veniaminof in September-October and in December; and continuing volcanogenic seismic swarms at Shishaldin Volcano throughout the year. Instrumentation and data acquisition highlights in 2002 were the installation of a subnetwork on Okmok Volcano, the establishment of telemetry for the Mount Veniaminof subnetwork, and the change in the data acquisition system to an EARTHWORM detection system. AVO located 7430 earthquakes during 2002 in the vicinity of the monitored volcanoes.

This catalog includes: (1) a description of instruments deployed in the field and their locations; (2) a description of earthquake detection, recording, analysis, and data archival systems; (3) a description of velocity models used for earthquake locations; (4) a 
summary of earthquakes located in 2002; and (5) an accompanying UNIX tar-file with a summary of earthquake origin times, hypocenters, magnitudes, and location quality statistics; daily station usage statistics; and all HYPOELLIPSE files used to determine the earthquake locations in 2002.

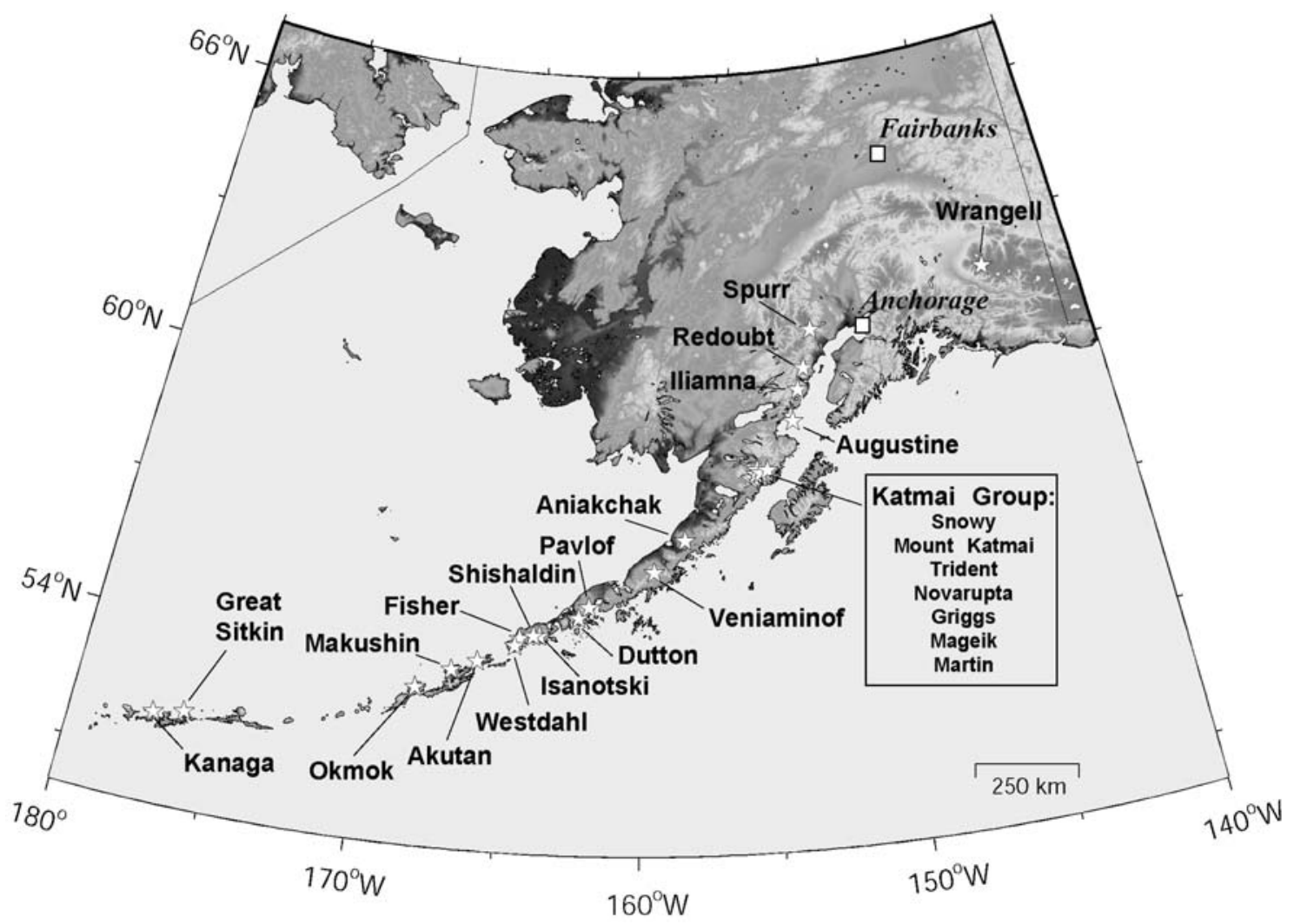

Figure 1. Alaskan volcanoes seismically instrumented by AVO in 2002. Stars show the location of volcanoes and squares show the location of Anchorage and Fairbanks.

\section{Instrumentation}

In 2002, a new subnetwork was installed at Okmok Volcano (eight singlecomponent stations) and telemetry was established for the Mount Veniaminof subnetwork. The only change in the existing seismic network was with the Aniakchak subnetwork. The seismic station AJAX was removed and a new station, AZAC, was installed $0.5 \mathrm{~km}$ to the northwest of the previous location of AJAX. At the end of 2002, there were 140 permanent seismic stations representing 178 components. In addition to 
the permanent stations installed by AVO, preliminary work was done for eight broadband sites on Akutan and Okmok Volcanoes planned to be installed in 2003.

Station locations and installation dates for all AVO stations operated during 2002 are contained in Appendix B. Maps showing the locations of stations with respect to individual volcanoes are contained in Appendix C. Other station information such as station calibration information is contained in the HYPOELLIPSE input files and is available for download via computer network as a compressed Unix tar-file. Estimates of each station's operational status through the catalog period are given in Appendix F.

AVO operated 123 short-period vertical-component seismic stations during 2002. All these stations had Mark Products L4 or Teledyne-Geotech S-13 seismometers with a one-second natural period. AVO also operated 16 three-component, short-period instruments during the catalog period. The instruments used at the three component stations were Mark Products L22 seismometers with a 0.5-second period, Mark Products L4 seismometers with a one-second period and Teledyne-Geotech S-13 instruments with a one-second natural period. Guralp CMG-40T 60-second natural period broadband instruments were operated on Augustine Island (AUL) and Akutan Island (AKT) during the report period.

Data were telemetered using voltage-controlled oscillators (VCOs) to transform the ground motion signals from the seismometers to frequency-modulated signals suitable for transmission over a radio link or telephone circuit. AVO used both the A1VCO (Rogers and others, 1980) and McVCO (McChesney, 1999) to modulate signals in the field. These signals were subsequently transmitted via UHF and VHF radio to communication hubs located in Adak, Akutan, Anchorage, Cold Bay, Dutch Harbor, Homer, Kasilof, King Cove, King Salmon, Port Heiden, Sourdough, Sterling, and Tolsona. Signals were then relayed via leased telephone circuits to AVO offices in Anchorage and Fairbanks where the signals were digitized. At the Homer communications hub, the data were digitized at the hub and then directed to AVO offices by modem. 


\section{Data Acquisition and Reduction}

In January-February 2002, data from AVO subnetworks were digitally recorded at $100 \mathrm{~Hz}$ in event-detection mode on PC computers using a modified version of the computer program XDETECT (Rogers, 1993). This program allowed each individual subnetwork to trigger independently. For regional events, a trigger for each subnetwork detecting the event was generated. The event-detected files were transferred to a Sun microcomputer and converted to $\mathrm{AH}$ format for routine processing. During the format conversion a one letter code is added to the AH file name to indicate which volcano subnetwork triggered the network. These XDETECT codes are summarized in Table 1.

Table 1: Volcano Subnetwork Designators

\begin{tabular}{|c|c|c|}
\hline Volcano Subnetwork & XDETECT Code & EARTHWORM Code \\
\hline Akutan Peak & $\mathrm{t}$ & $\mathrm{ak}$ \\
\hline Aniakchak Crater & $\mathrm{n}$ & $\mathrm{an}$ \\
\hline Augustine Volcano & $\mathrm{a}$ & $\mathrm{au}$ \\
\hline Mount Dutton & $\mathrm{d}$ & $\mathrm{dt}$ \\
\hline Iliamna Volcano & $\mathrm{i}$ & $\mathrm{il}$ \\
\hline Great Sitkin Volcano & $\mathrm{f}$ & $\mathrm{gs}$ \\
\hline Kanaga Volcano & $\mathrm{f}$ & $\mathrm{ki}$ \\
\hline Katmai volcanic group & $\mathrm{k}$ & $\mathrm{ka}$ \\
\hline Makushin Volcano & $\mathrm{m}$ & $\mathrm{ma}$ \\
\hline Pavlof Volcano & $\mathrm{v}$ & $\mathrm{pv}$ \\
\hline Redoubt Volcano & $\mathrm{r}$ & $\mathrm{rd}$ \\
\hline Regional event & no subnet code & rg \\
\hline Shishaldin Volcano & $\mathrm{h}$ & $\mathrm{sh}$ \\
\hline Mount Spurr & $\mathrm{s}$ & $\mathrm{sp}$ \\
\hline Mount Veniaminof & $\mathrm{e}$ & $\mathrm{vn}$ \\
\hline Westdahl Peak & $\mathrm{w}$ & we \\
\hline Mount Wrangell & $\mathrm{g}$ & wa \\
\hline
\end{tabular}

In March 2002, a major change was made in the event acquisition system employed by the AVO. The older PC based event acquisition system was replaced by an EARTHWORM acquisition system (Johnson and others, 1995) to standardizing operations with other USGS Volcano Observatories. Two duplicate EARTHWORM acquisition systems were set up in AVO offices in Anchorage and Fairbanks, to provide a backup in case of failure at either location. At this time, the archival format was changed from $\mathrm{AH}$ to SAC. 
As in the previous detection system, data were triggered based on individual subnets but unlike the previous system, triggered data from regional events were collected into a single trigger. The EARTHWORM modules Carlstatrig and Carlsubtrig was used to create the earthquake triggers. The Carlstatrig parameters were set as follows: LTAtime $=8$ seconds, Ratio $=2.3$, and Quiet $=4$. Carlsubtrig was modified so that a two-letter code was appended to the filename of each trigger to identify which subnetwork triggered or if the event was a regional trigger. These EARTHWORM codes are summarized in Table 1.

Event triggers from both detection systems were processed using the interactive seismic data analysis program XPICK (Robinson, 1990), and the earthquake location program HYPOELLIPSE (Lahr, 1999). Each event trigger was visually inspected and classified as either a volcano-tectonic, long-period, hybrid, regional-tectonic, teleseismic, shore-ice, calibration, other non-seismic, or cause unknown event. This classification system was modeled after that described by Lahr and others (1994). The type of event was identified by a classification code (Table 2) and stored in the event location pick file. Event triggers that were created by false signals were deleted at this time. Table 2 shows the classification codes used. Events classified as volcano-tectonic, long-period, or hybrid and having five or more distinct phases at four or more stations were selected for location. Earthquakes with a P-wave and S-wave separation of more than five seconds on the closest stations to the event were assumed to come from non-volcanic sources and

Table 2: Classification codes

\begin{tabular}{|c|c|}
\hline Event Classification & Classification Code \\
\hline Volcano-Tectonic & $\mathrm{a}$ \\
\hline Long-Period & $\mathrm{b}$ \\
\hline Hybrid & $\mathrm{h}$ \\
\hline Regional-Tectonic & $\mathrm{E}$ \\
\hline Teleseismic & $\mathrm{T}$ \\
\hline Shore-Ice & $\mathrm{i}$ \\
\hline Calibrations & $\mathrm{C}$ \\
\hline Other non-seismic & $\mathrm{o}$ \\
\hline Cause unknown & $\mathrm{x}$ \\
\hline
\end{tabular}

were typically discarded. The quality of each hypocenter were checked using a computer algorithm that identified events without magnitude, with fewer than three P-phases, with 
less than one S-phase, and with standard hypocentral errors greater than $15 \mathrm{~km}$. Events not meeting these requirements after further evaluation were removed from the final catalog listing. For the earthquakes located, the average horizontal error was $1.8 \mathrm{~km}$, the average vertical error was $2.8 \mathrm{~km}$, the average number of P-phases used was 6.5, and the average number of S-phases used was 4.8.

\section{Velocity Models}

AVO currently employs eight local velocity models and one regional seismic velocity model (Appendix D) to locate earthquakes at the twenty-four monitored volcanoes. All velocity models are one-dimensional models utilizing horizontal layers to approximate the local seismic velocity structures. Each model, with one exception, assumes a series of constant velocity layers. The single exception is the Akutan velocity model (Power and others, 1996), which has a velocity gradient in the top layer overlying a layer with a constant velocity. The local velocity models were developed using a variety of methods.

One or more vertical cylinders are used to model the volcanic source zones on all volcanoes where a local volcano-specific velocity model exists. Earthquakes within these cylindrical volumes are located with a local model and earthquakes outside of the cylindrical volumes are located with the regional model. All cylindrical volumes have a radius of $20 \mathrm{~km}$ with the exception of the cylinder centered on Shishaldin Volcano. The cylinder centered on Shishaldin Volcano has a radius of $30 \mathrm{~km}$ in order to encompass Isanotski Peaks. The top of each cylinder is set at a depth of $-3 \mathrm{~km}$ (1.e. $3 \mathrm{~km}$ elevation) with respect to sea level and the bottom is set at a depth of $50 \mathrm{~km}$ with respect to sea level.

The Akutan, Augustine (Power, 1988), and Iliamna (Roman and others, 2001) velocity models are used to locate hypocenters that lie within a single cylindrical volume centered on each volcano. The Cold Bay velocity model (McNutt and Jacob, 1986) is used to locate hypocenters that fall within single cylindrical volumes centered on Mount Dutton and Pavlof Volcano. Hypocenters on Fisher Caldera, Isanotski Peaks, Shishaldin Volcano, and Westdahl Peak that fall within the cylindrical regions centered on Shishaldin Volcano and Westdahl Peak and are located with the Cold Bay velocity 
model. Five overlapping cylinders define the area in which the Spurr velocity model (Jolly and others, 1994) is used, four overlapping cylinders define the area in which the Redoubt velocity model (Lahr and others, 1994) is used, and four overlapping cylinders define the area in which the Katmai model (Jolly, 2000) is used. The Andreanof velocity model (Toth and Kisslinger, 1984) is used to locate hypocenters within a volume defined by three cylinders centered on Kanaga Volcano, Mount Moffet, and Great Sitkin Volcano. Specific velocity models for Aniakchak Crater, Makushin Volcano, Mount Veniaminof, and Mount Wrangell have not been developed, thus the regional velocity model (Fogleman and others, 1993) is used to locate hypocenters surrounding these volcanoes. The cylindrical model parameters, regional velocity model, and volcanospecific models used to locate earthquakes in this report are summarized in Appendix D. Figures showing the volcanic source zones modeled by cylinders in map view are shown in Appendix E.

\section{Seismicity}

The 7430 earthquakes located in 2002 represent a significant increase in the total number

of hypocenters determined by AVO in a single calendar year. This is a dramatic increase from the 1488 earthquakes located in 2001. The numbers of located events for each volcano subnetwork are shown in Table 3. We attribute the increase in located events to the change in the triggering algorithm since increases in detected seismic activity were seen on the majority of subnetworks after the change in the triggering algorithm. If one excludes earthquake swarms located at Snowy Mountain, Shishaldin Volcano and in the Adak region, the effect of the change in the event detection system was a three-fold increase in the number of earthquakes located. If the 2002 earthquake swarms are included, the increase in located events was 450\%. Decreases in activity were only seen in the Aniakchak and Makushin subnetworks. At Aniakchak the seismicity rate is low and during 2002, the field instrumentation was plagued by failures that make rate comparisons difficult. In 2001, we located 158 earthquakes at Makushin, which is comparable to the 109 earthquakes located during 2002, and within the normal range of variation. 
Table 3: Number of earthquakes located for each subnetwork in 2002.

\begin{tabular}{|c|c|c|}
\hline Volcano Subnetwork & $\begin{array}{c}\text { Earthquakes located in } \\
\mathbf{2 0 0 1}\end{array}$ & $\begin{array}{c}\text { Earthquakes located in } \\
\mathbf{2 0 0 2}\end{array}$ \\
\hline Mount Wrangell & 72 & 314 \\
\hline Mount Spurr & 30 & 420 \\
\hline Redoubt Volcano & 24 & 91 \\
\hline Iliamna Volcano & 41 & 311 \\
\hline Augustine Volcano & 70 & 226 \\
\hline Katmai volcanic group & 540 & 1581 \\
\hline Aniakchak Crater & 12 & 4 \\
\hline Mount Veniaminof & no network installed & 18 \\
\hline Pavlof Volcano & 13 & 88 \\
\hline Mount Dutton & 2 & 0 \\
\hline Shishaldin Volcano & 51 & 2620 \\
\hline Westdahl Peak & 3 & 11 \\
\hline Akutan Peak & 3 & 30 \\
\hline Makushin Volcano & 158 & 109 \\
\hline Great Sitkin Volcano & 165 & 417 \\
\hline Kanaga Volcano & 7 & 21 \\
\hline Totals & 1488 & 7430 \\
\hline
\end{tabular}

\section{Summary}

Between January 1, 2002, and December 31, 2002, AVO located 7430

earthquakes that occurred at or near volcanoes in Alaska. Highlights of the AVO seismic monitoring program include low frequency tremor and long period events at Mount Veniaminof, continuing seismic swarms at Shishaldin Volcano, and earthquake swarms near Snowy Mountain and Great Sitkin Volcano. A new seismic subnetwork was installed on Okmok Volcano.

Available for download with this report is a compressed Unix tar-file containing a summary listing of earthquake hypocenters and all the necessary HYPOELLIPSE files including station information, model information, and phase information to relocate earthquake hypocenters. The reader should refer to Lahr (1999) for information on file formats and instructions for configuring and running the location program HYPOELLIPSE. Archives of waveform data are maintained on CDROM at AVO offices in Fairbanks and Anchorage. 


\section{Acknowledgements}

The contents of this report reflect a great deal of hard work by a large number of people including AVO, AEIC, and USGS personnel and various students, interns and volunteers. We thank Jackie Caplan-Auerbach, Ben Pauk, and Stephanie Prejean, for formal reviews of the text and figures. 


\section{References}

Dixon, J.P, Stihler, S.D., Power J.A., Tytgat, G., Estes, S., Moran, S.C., Paskievitch, J., McNutt, S.R., 2002, Catalog of Earthquake Hypocenters at Alaska Volcanoes: January 1, 2000 - December 31, 2001: U.S. Geological Survey Open-file Report 02-342, 56p.

Fogleman, K.A., Lahr, J.C., Stephens, C.D., and Page, R.A., 1993, Earthquake locations determined by the southern Alaska seismograph network for October 1971 through May 1989: U.S. Geological Survey Open-file Report 93-309, 54p.

Johnson, C.E., Bittenbinder, A., Bogaert, B., Dietz, L., Kohler, W., 1995, EARTHWORM: A Flexible Approach to Seismic Network Processing, Incorporated Research Institutions for Seismology Newsletter, v. 14, no. 2, p. 1-4.

Jolly, A.D., Page, R.A., and Power, J.A., 1994, Seismicity and stress in the vicinity of Mt. Spurr volcano, south-central Alaska: Journal of Geophysical Research, v. 99, p. 15305-15318.

Jolly, A.D, Power, J.A., Stihler, S.D., Rao, L.N., Davidson, G., Paskievitch, J., Estes, S., Lahr, J.C., 1996, Catalog of earthquake hypocenters for Augustine, Redoubt, Iliamna, and Mount Spurr Volcanoes, Alaska: January 1, 1991 - December 31, 1993: U.S. Geological Survey Open-file Report 96-70, 90p.

Jolly, A.D., 2000, Subsurface structure of the volcanoes in Katmai National Park, Alaska: University of Alaska Fairbanks, Ph.D thesis, 169p.

Jolly, A.D., Stihler, S.D., Power, J.A., Lahr, J.C., Paskievitch, J., Tytgat, G., Estes, S., Lockhart, A.B., Moran, S.C., McNutt, S.R., Hammond, W.R., 2001, Catalog of earthquake hypocenters at Alaskan Volcanoes: January 1, 1994 - December 31, 1999: U.S. Geological Survey Open-file Report 01-189, 202p.

Lahr, J.C., 1999, HYPOELLIPSE: A Computer Program for Determining Local Earthquake Hypocentral Parameters, Magnitude, and First Motion Pattern: U.S. Geological Survey Open File Report 99-23, 116p.

Lahr, J.C, Chouet, B.A., Stephens, C.D., Power, J.A., Page, R.A., 1994, Earthquake classification, location, and error analysis in a volcanic environment: Implications for the magmatic system of the 1989-90 eruptions at Redoubt Volcano, Alaska: Journal of Volcanology and Geothermal Research, v. 62, p. 137-152.

McChesney, P. J., 1999, McVCO Handbook 1999: U.S. Geological Survey, Open-File Report 99-361, 48p.

McNutt, S.R., and Jacob, K.H., 1986, Determination of large-scale velocity structure of the crust and upper mantle in the vicinity of Pavlof volcano, Alaska: Journal of Geophysical Research, v. 91, p. 5013-5022. 
Power, J.A., 1988, Seismicity associated with the 1986 eruption of Augustine Volcano, Alaska: University of Alaska Fairbanks, Masters thesis, 149p.

Power, J.A., Paskievitch, J.F., Richter, D.H., McGimsey, R.G., Stelling, P., Jolly, A.D., Fletcher, H.J., 1996, 1996 seismicity and ground deformation at Akutan Volcano, Alaska: EOS Transactions of the American Geophysical Union, v. 77, p. F514.

Power, J.A., March, G.D., Lahr, J.C., Jolly, A.D., Cruse, G.R., 1993, Catalog of earthquake hypocenters at Redoubt Volcano and Mount Spurr, Alaska: October 12, 1989December 31, 1990: U.S. Geological Survey Open-File Report, 93-685-A, 57p.

Robinson, M., 1990, XPICK users manual, version 2.7: Seismology Lab, Geophysical Institute, University of Alaska Fairbanks, 93p.

Rogers, J.A., Maslak, S., and Lahr, J.C., 1980, A seismic electronic system with automatic calibration and crystal reference: U.S. Geological Survey Open-file Report 80324, 130p.

Rogers, J.A., 1993, Xdetect version 3.18 user’s reference guide: U.S. Geological Survey Open-file Report 93-261, 18p.

Roman, D.C., Power, J.A., Moran, S.C., Cashman, K.V., Stihler, S.D., 2001, Unrest at Iliamna Volcano, Alaska in 1996, Evidence for a magmatic intrusion: EOS Transactions of the American Geophysical Union, v. 82, p. F1329.

Toth, T., and Kisslinger, C., 1984, Revised focal depths and velocity model for local earthquakes in the Adak seismic zone: Bulletin of the Seismological Society of America, v. 74, p. 1349-1360. 
Appendix A: Maps showing the locations of the earthquakes located in 2002.
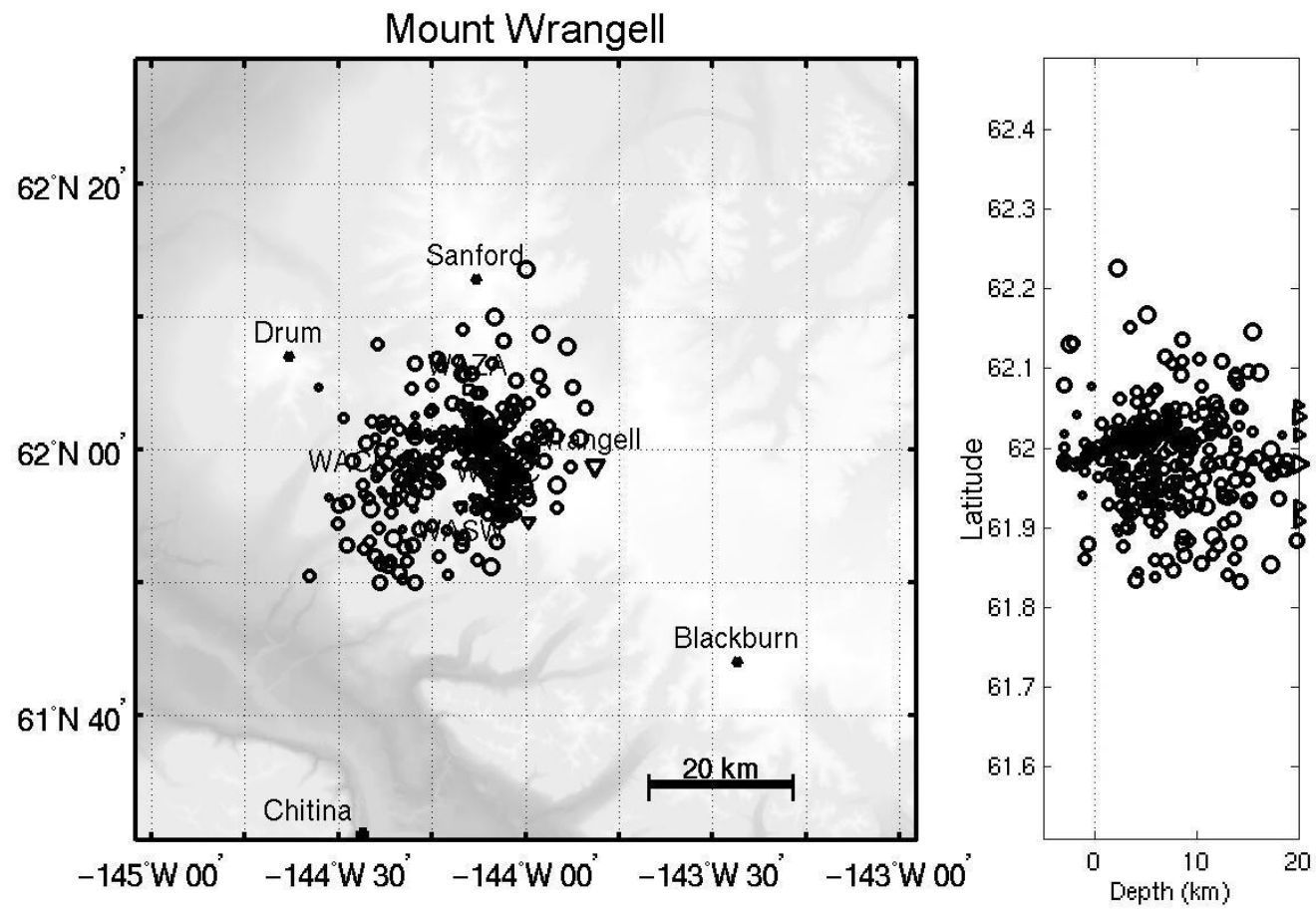

Mag. Symb. Size
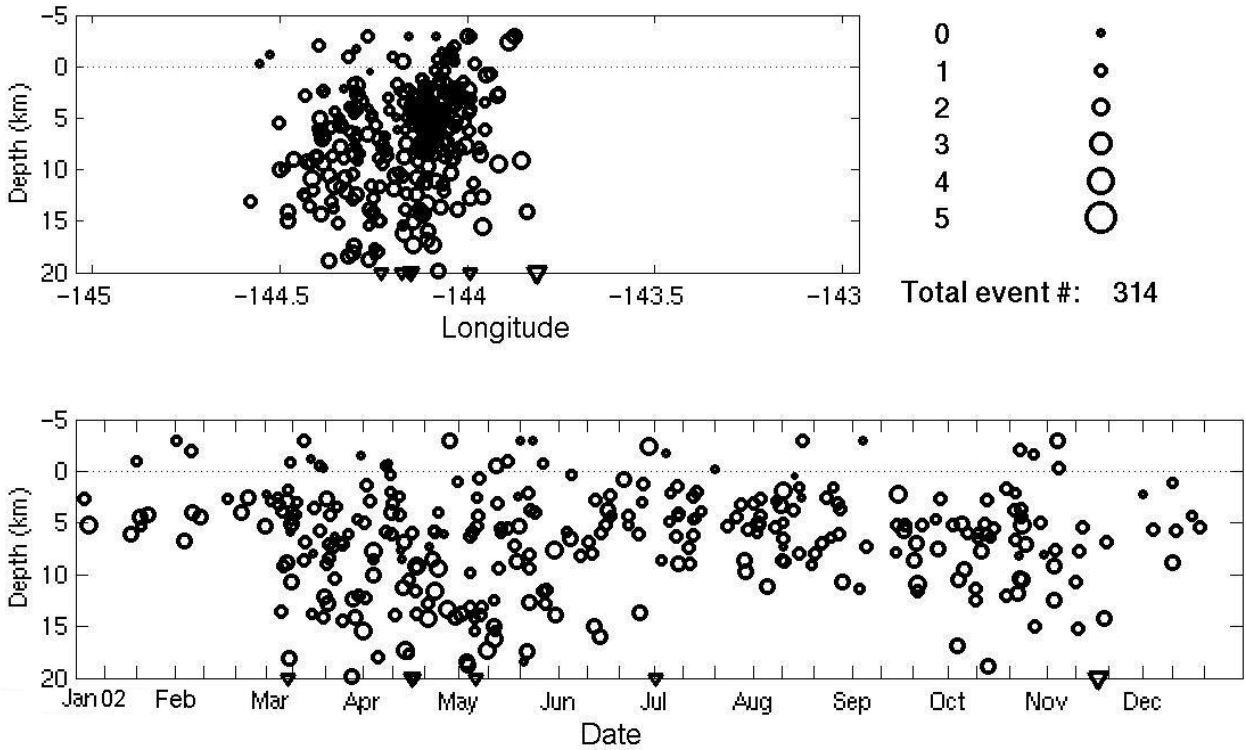

Figure A1. Summary plots of 314 earthquakes located near Mount Wrangell in 2002. Open circles scaled with magnitude show hypocenter locations shallower than $20 \mathrm{~km}$. Hypocenters with depths of $20 \mathrm{~km}$ and deeper are shown by open triangles scaled with magnitude. Seismic stations are shown by open squares and labeled by station code. (See Appendix B for station information). Closed circles are used to show other points of interest. 

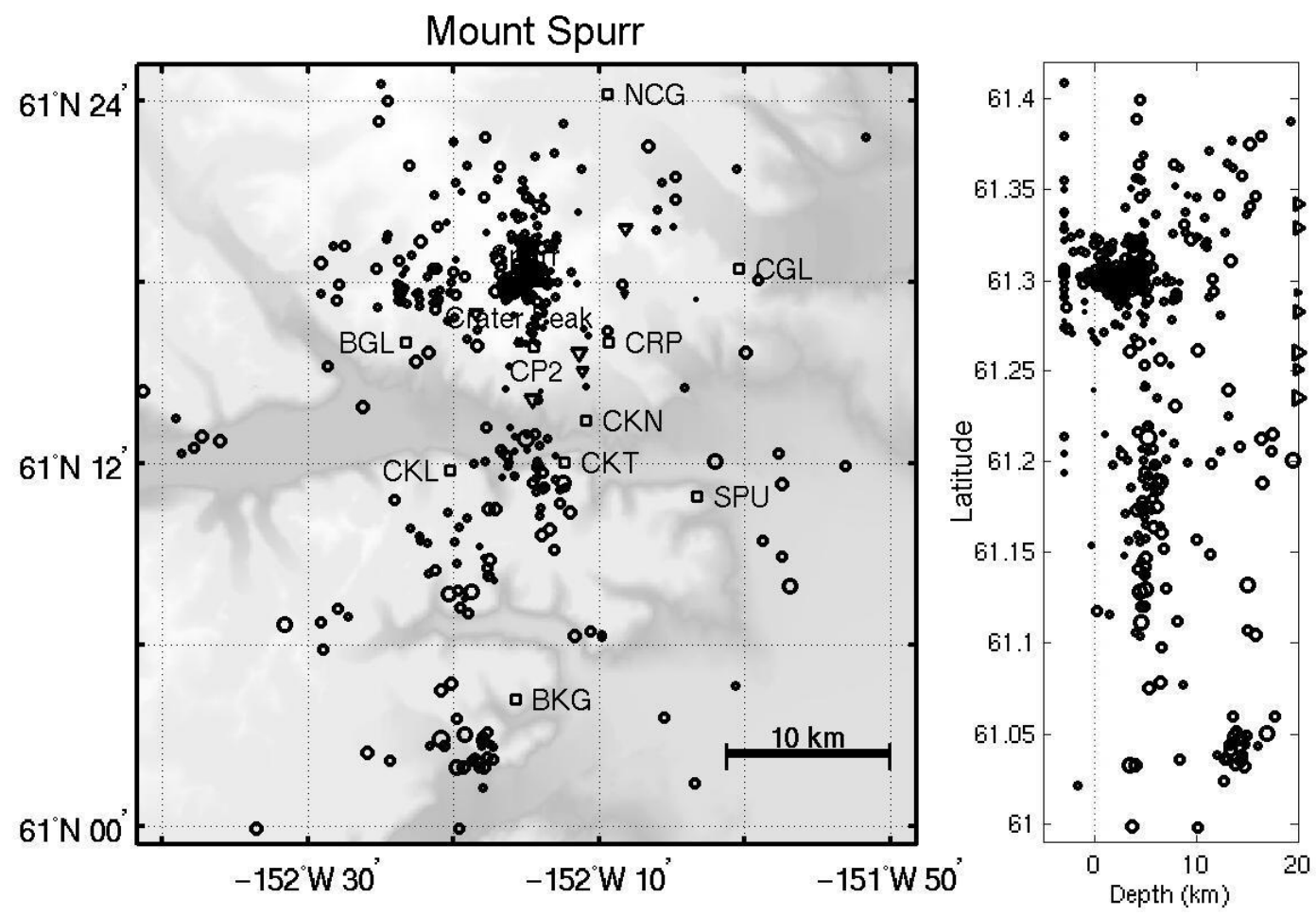

Mag. Symb. Size
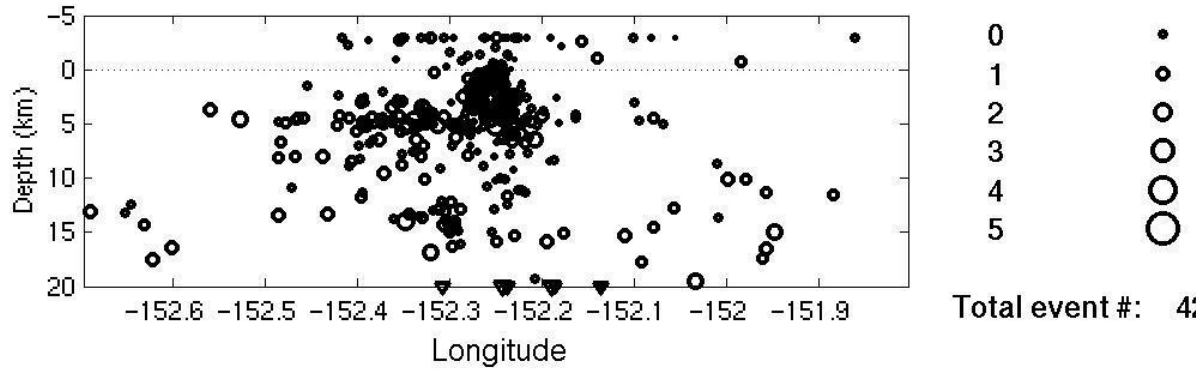

Total event \#: 420

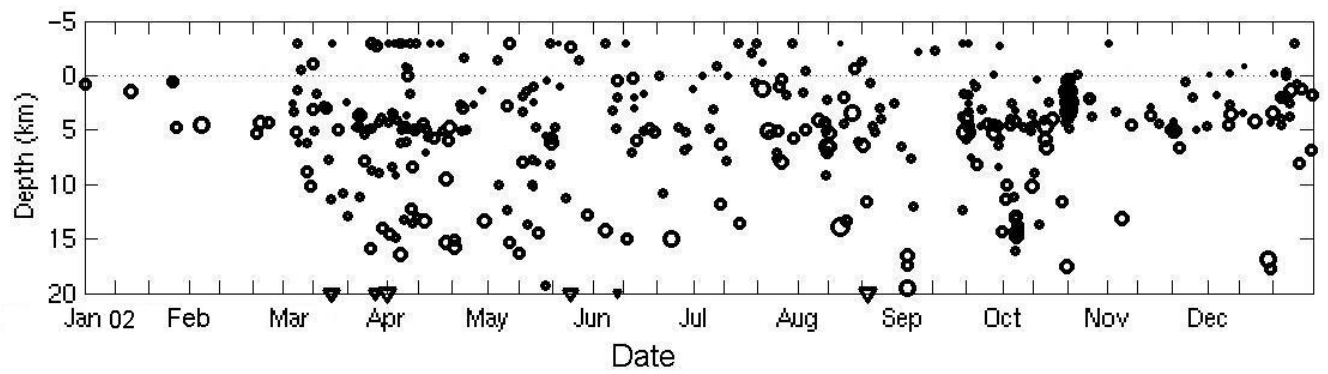

Figure A2. Summary plots of 420 earthquakes located near Mount Spurr in 2002. Open circles scaled with magnitude show hypocenter locations shallower than $20 \mathrm{~km}$. Hypocenters with depths of $20 \mathrm{~km}$ and deeper are shown by open triangles scaled with magnitude. Seismic stations are shown by open squares and labeled by station code. (See Appendix B for station information). Closed circles are used to show other points of interest. 

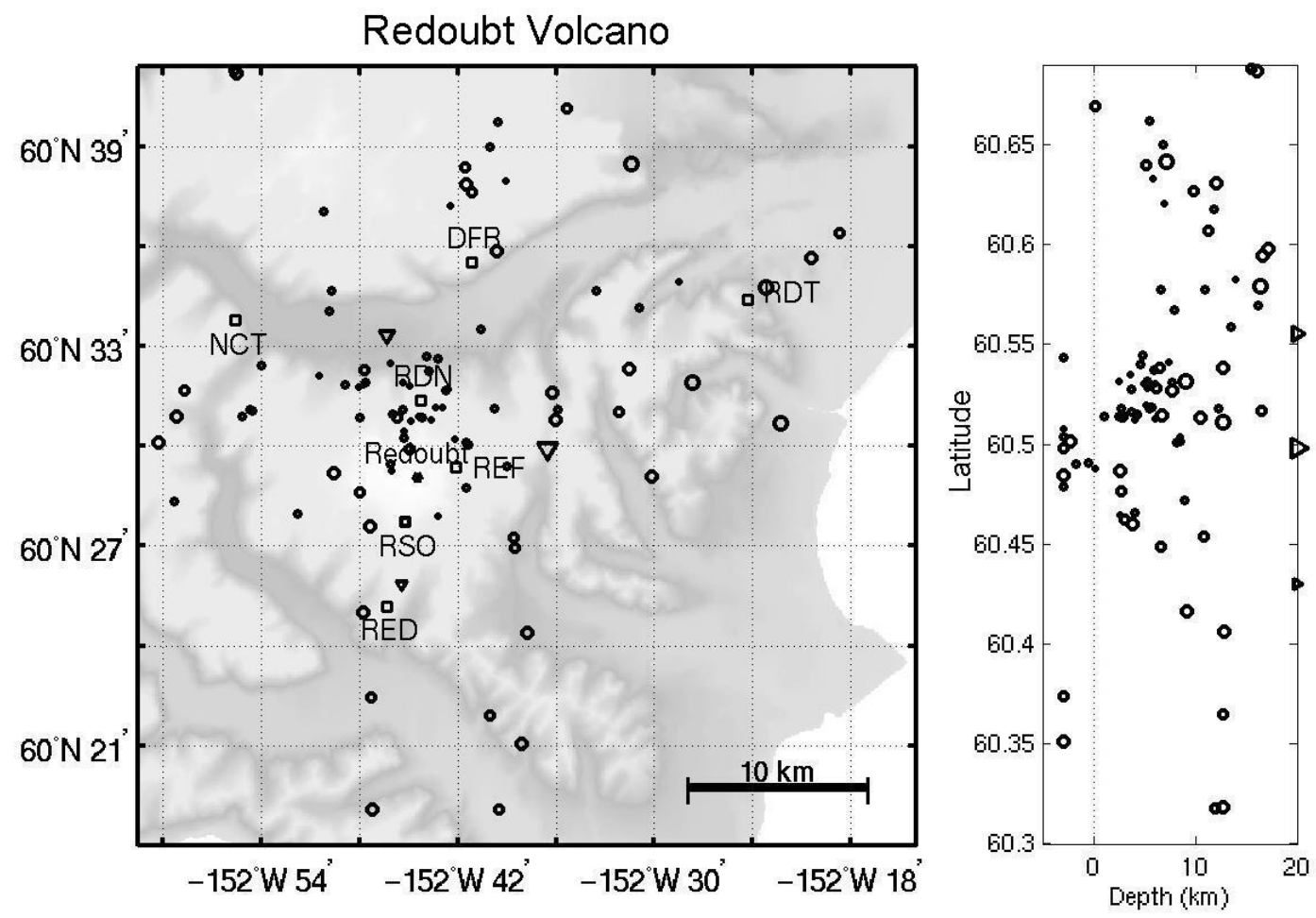

Mag. Symb. Size
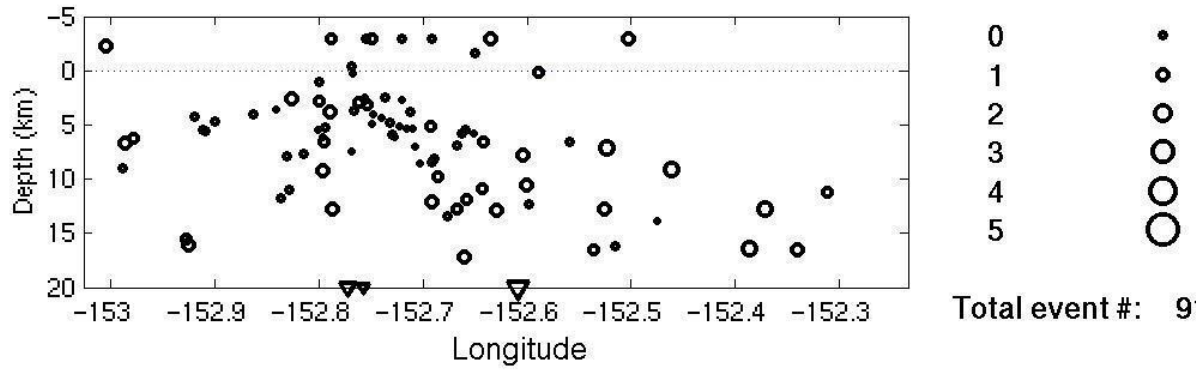

Total event \#: 91

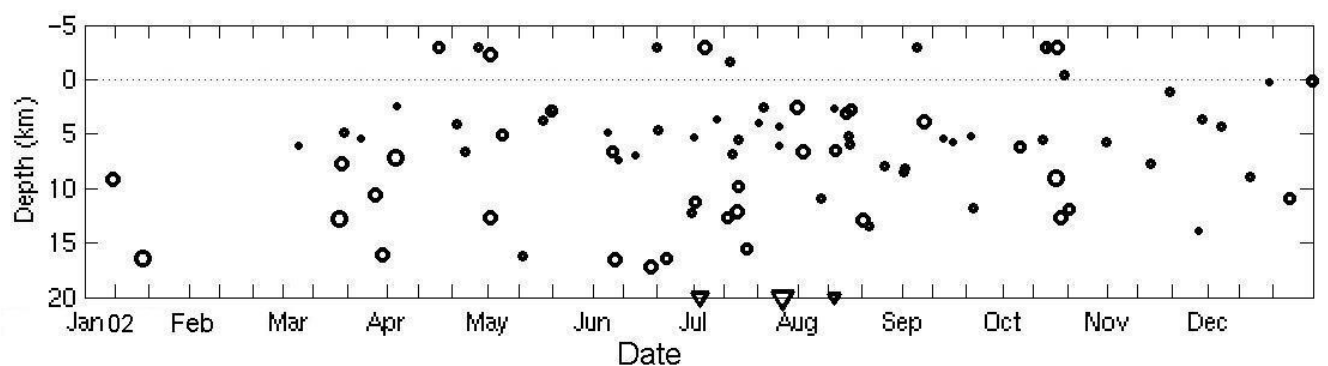

Figure A3. Summary plots of 91 earthquakes located near Redoubt Volcano in 2002. Open circles scaled with magnitude show hypocenter locations shallower than $20 \mathrm{~km}$. Hypocenters with depths of $20 \mathrm{~km}$ and deeper are shown by open triangles scaled with magnitude. Seismic stations are shown by open squares and labeled by station code. (See Appendix B for station information). Closed circles are used to show other points of interest. 

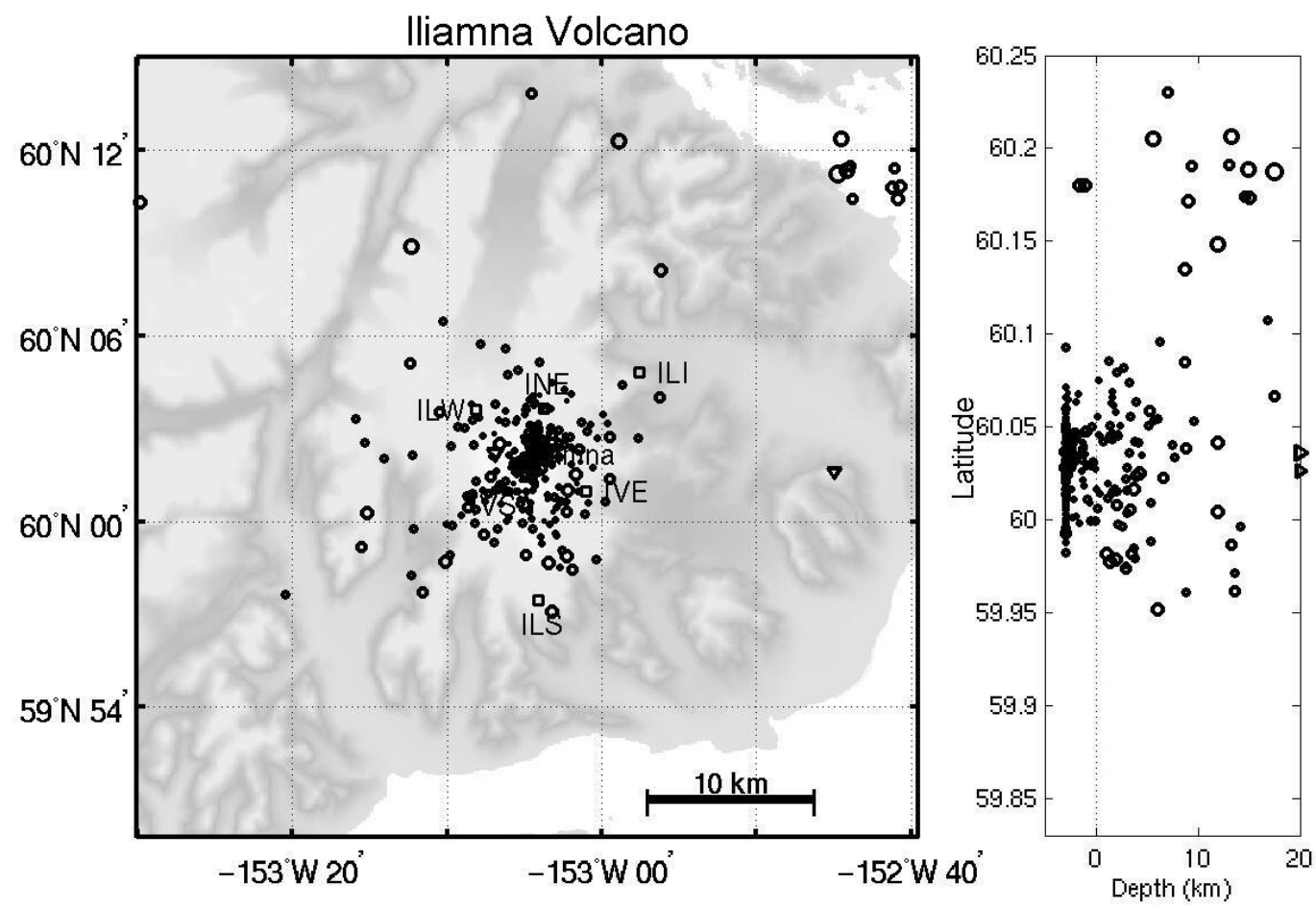

Mag. Symb. Size
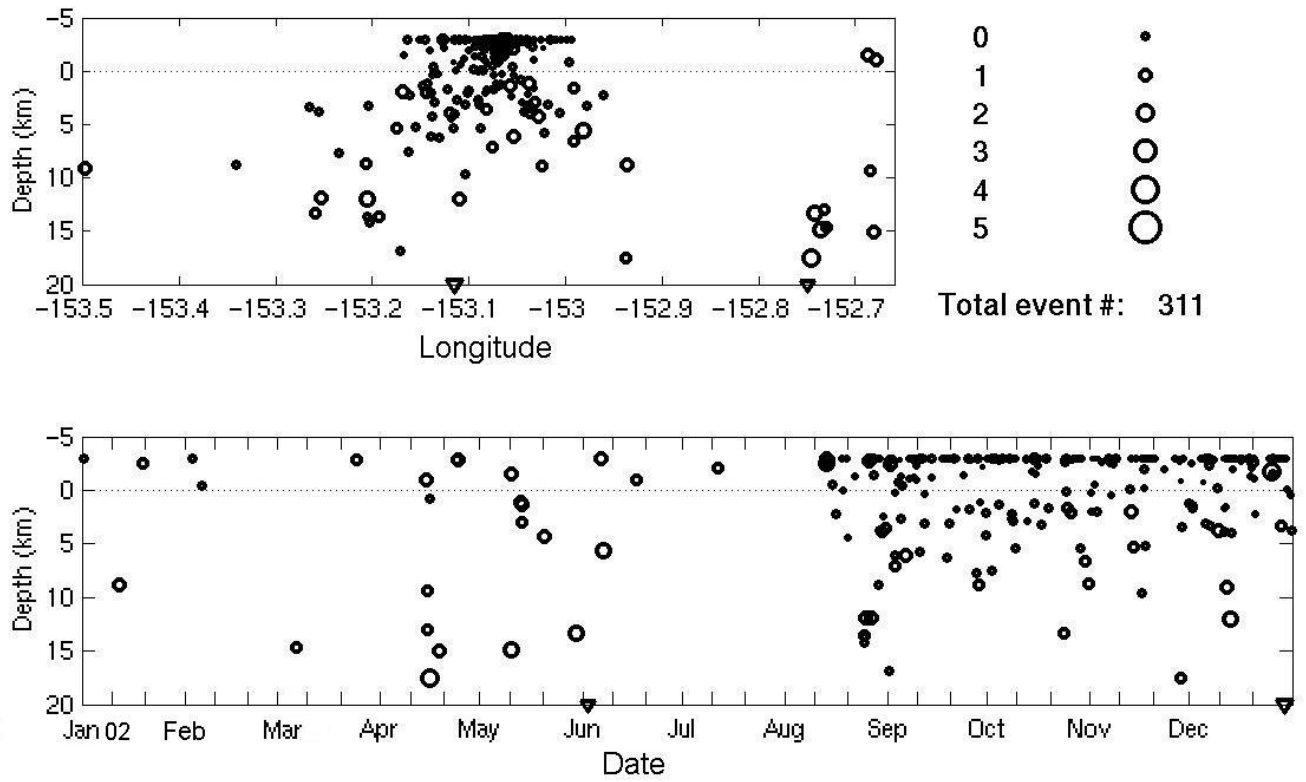

Figure A4. Summary plots of 311 earthquakes located near Iliamna Volcano in 2002. Open circles scaled with magnitude show hypocenter locations shallower than $20 \mathrm{~km}$. Hypocenters with depths of $20 \mathrm{~km}$ and deeper are shown by open triangles scaled with magnitude. Seismic stations are shown by open squares and labeled by station code. (See Appendix B for station information). Closed circles are used to show other points of interest. The apparent increase in activity is due to several Iliamna seismic stations coming back on-line in late August following the summer field season. 

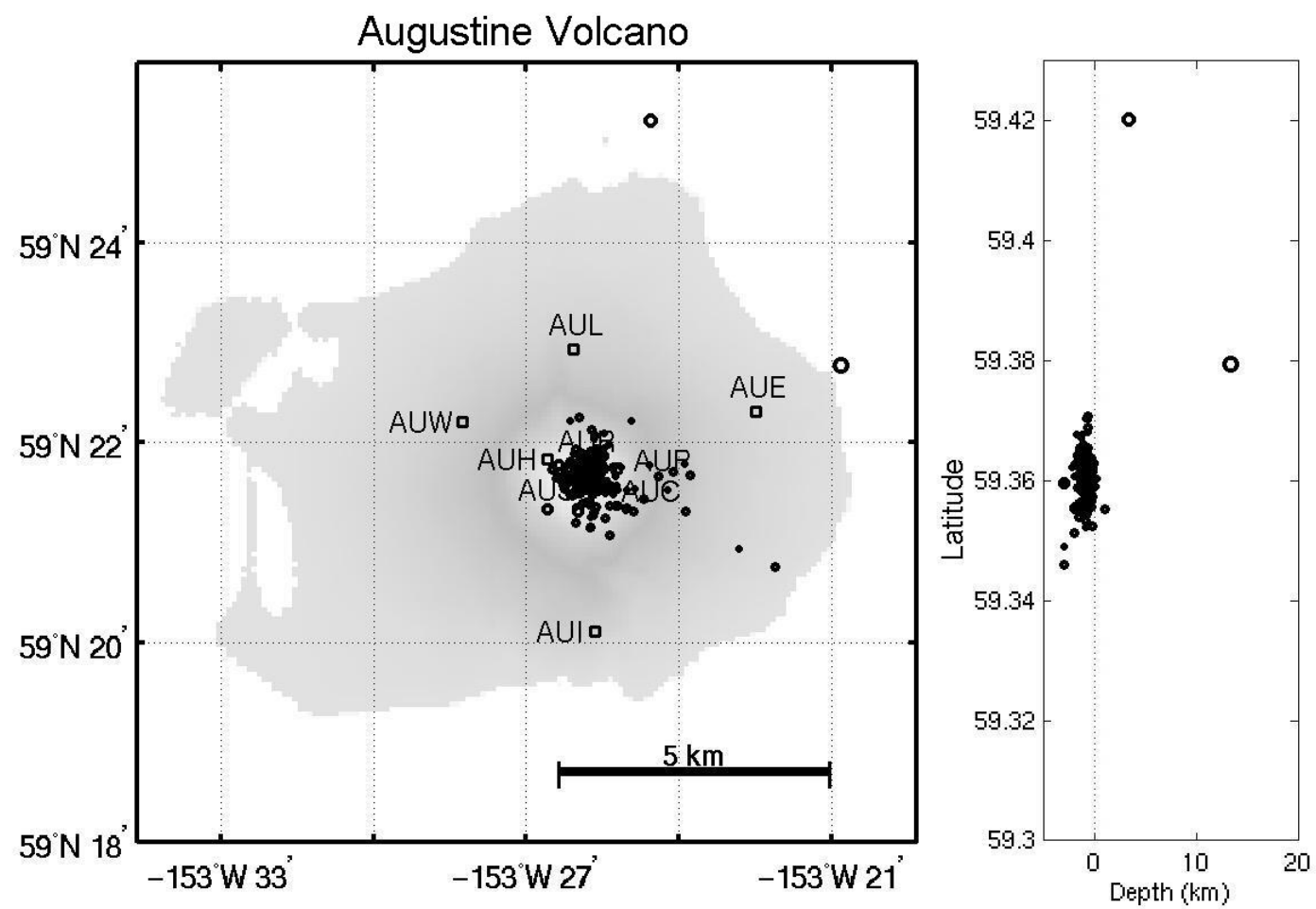

Mag. Symb. Size
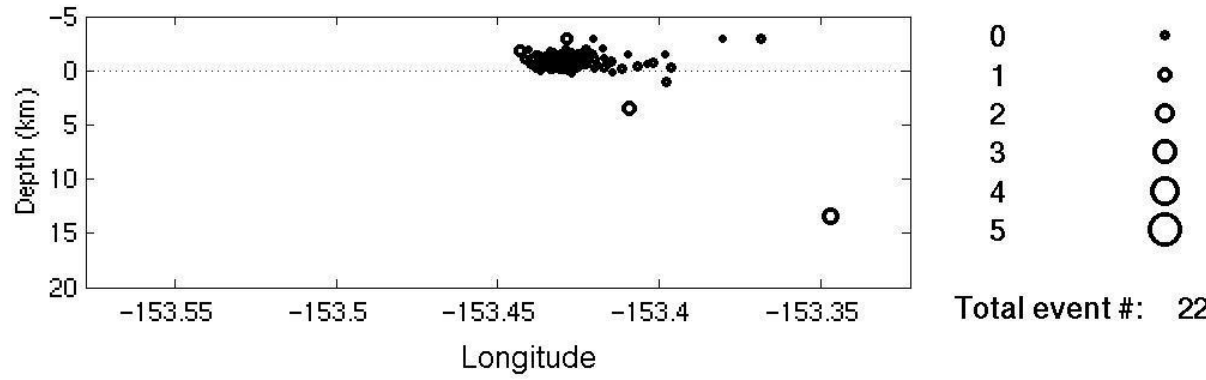

Total event \#: 226

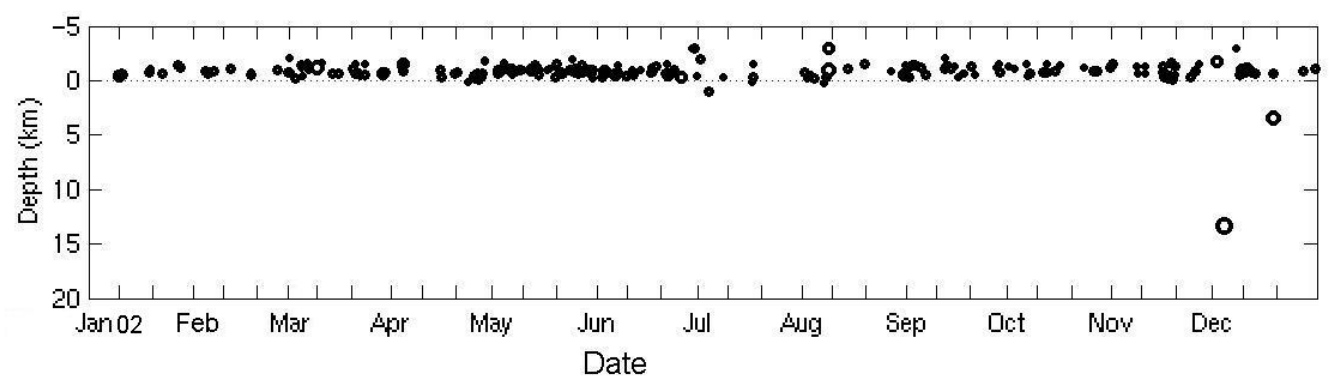

Figure A5. Summary plots of 226 earthquakes located near Augustine Volcano in 2002. Open circles scaled with magnitude show hypocenter locations shallower than $20 \mathrm{~km}$. Hypocenters with depths of $20 \mathrm{~km}$ and deeper are shown by open triangles scaled with magnitude. Seismic stations are shown by open squares and labeled by station code. (See Appendix B for station information). Closed circles are used to show other points of interest. 

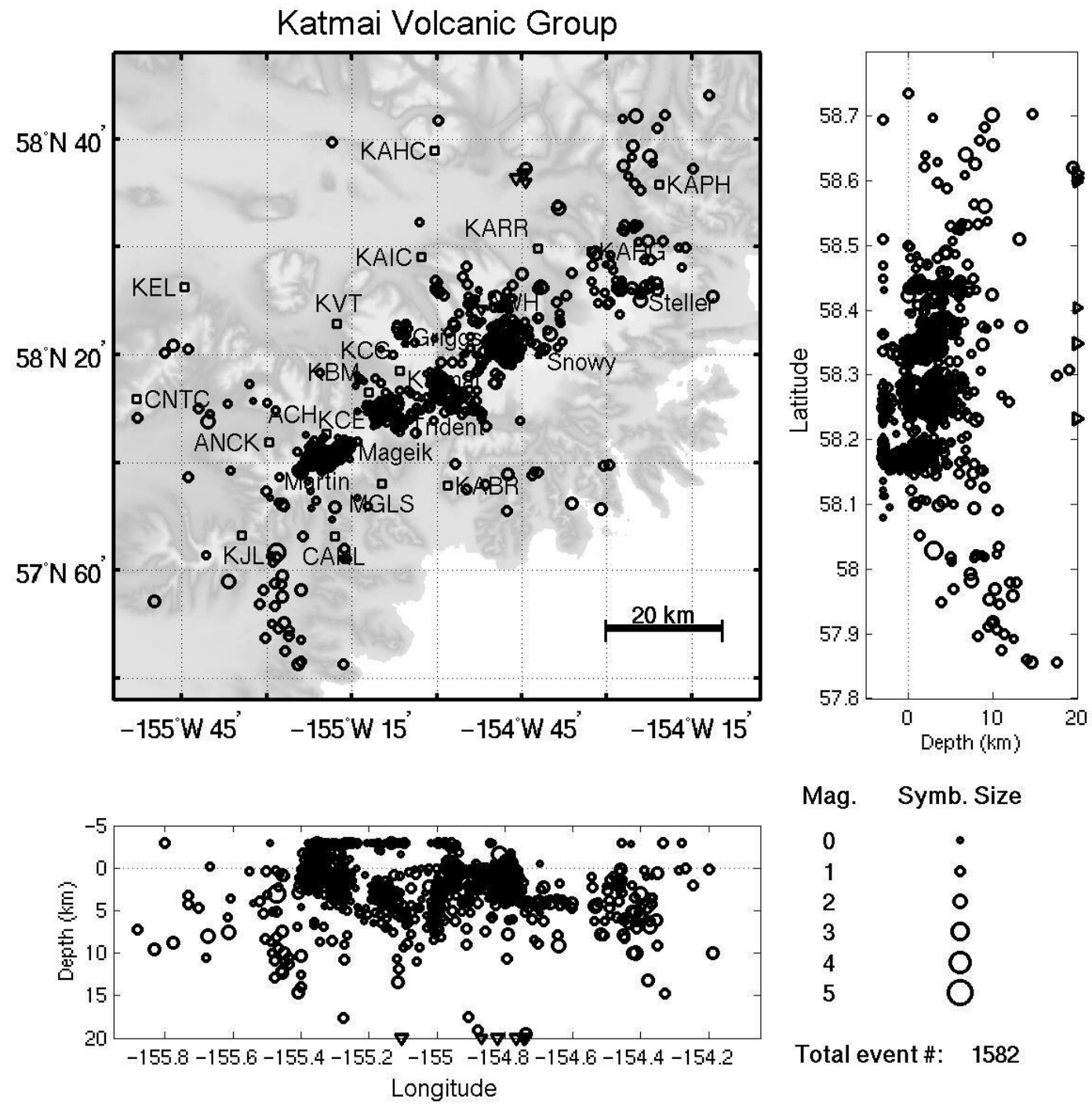

Mag. Symb. Size
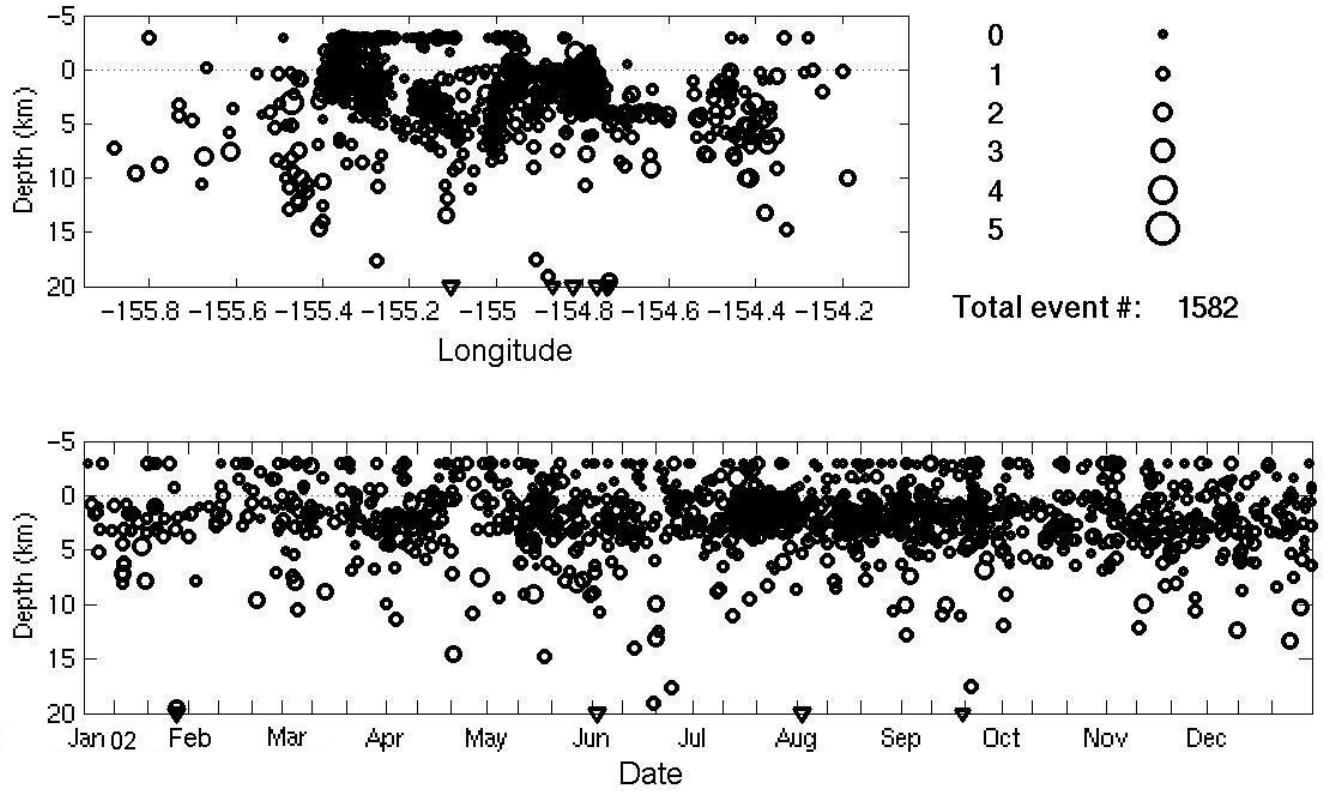

Figure A6. Summary plots of 1582 earthquakes located near the Katmai volcanic group in 2002. Open circles scaled with magnitude show hypocenter locations shallower than $20 \mathrm{~km}$. Hypocenters with depths of $20 \mathrm{~km}$ and deeper are shown by open triangles scaled with magnitude. Seismic stations are shown by open squares and labeled by station code. (See Appendix B for station information). Closed circles are used to show other points of interest. 

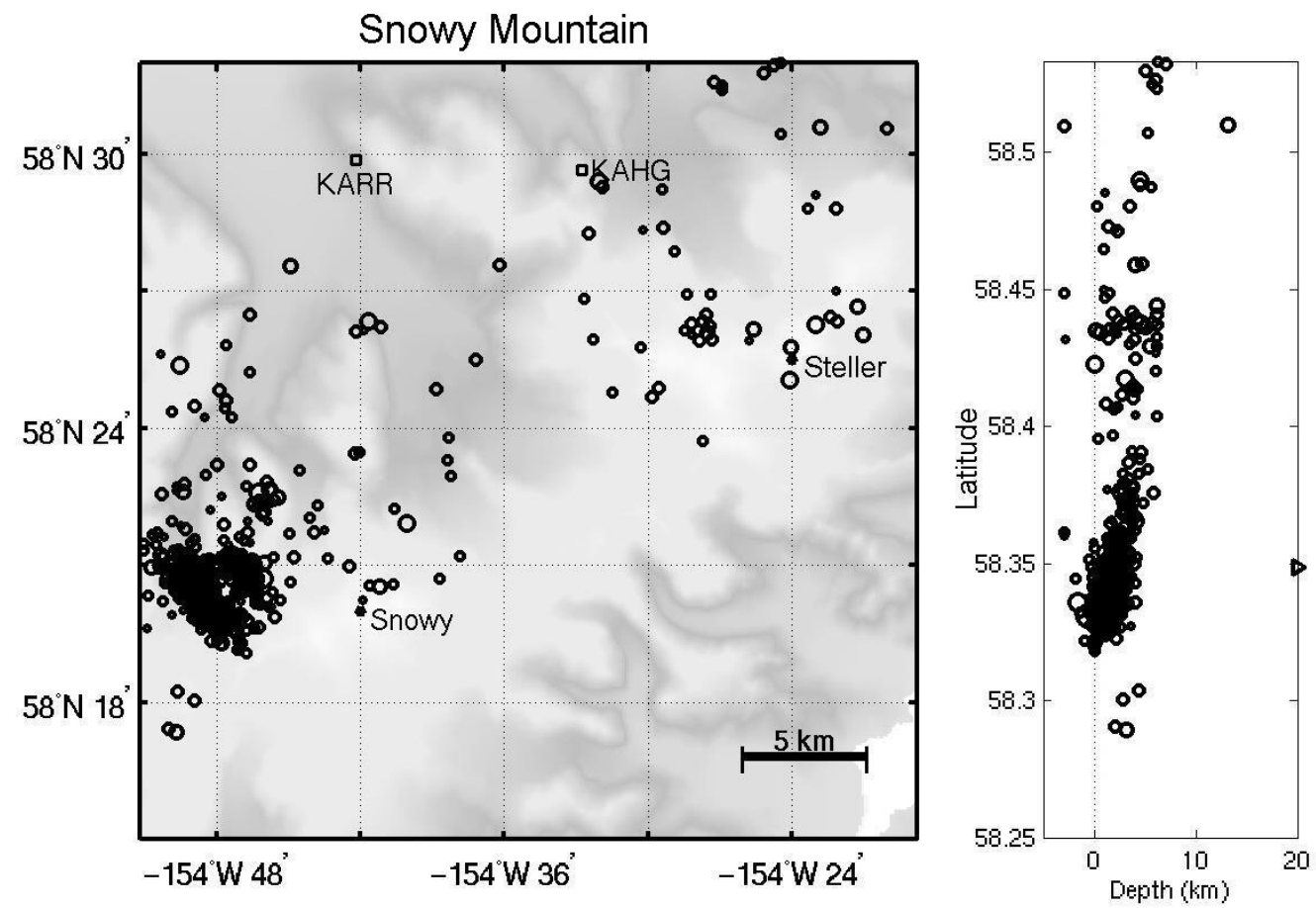

Mag. Symb. Size
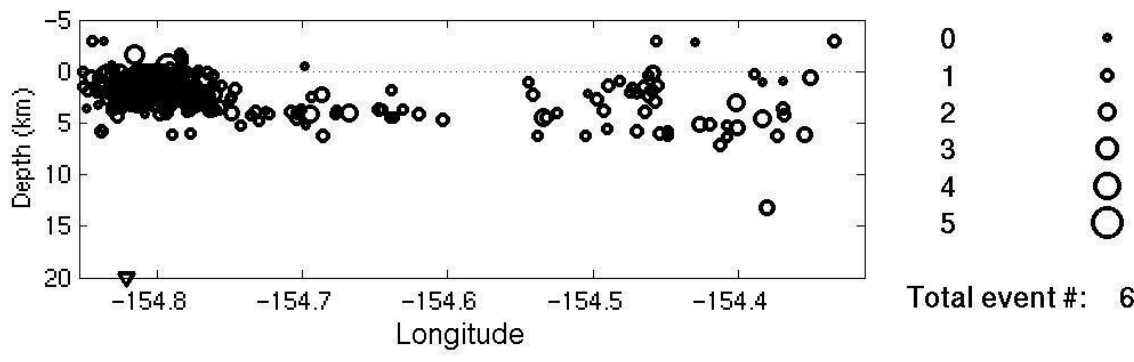

Total event \#: 643

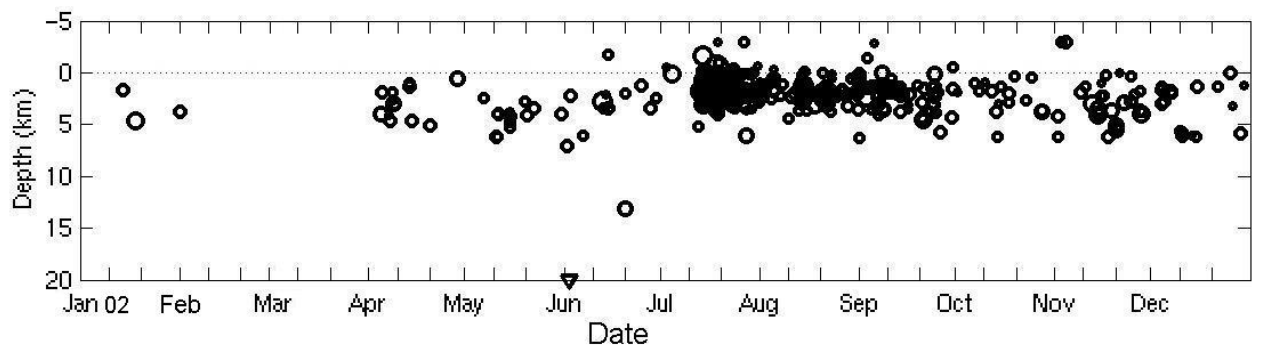

Figure A7. Summary plots of 643 earthquakes located near Snowy Mountain in the Katmai volcanic group in 2002. Open circles scaled with magnitude show hypocenter locations shallower than $20 \mathrm{~km}$. Hypocenters with depths of $20 \mathrm{~km}$ and deeper are shown by open triangles scaled with magnitude. Seismic stations are shown by open squares and labeled by station code. (See Appendix B for station information). Closed circles are used to show other points of interest. The earthquake swarm 5-10 km west of Snowy Mountain in July-September accounts for $85 \%$ of all earthquakes in the Snowy Mountain region. 

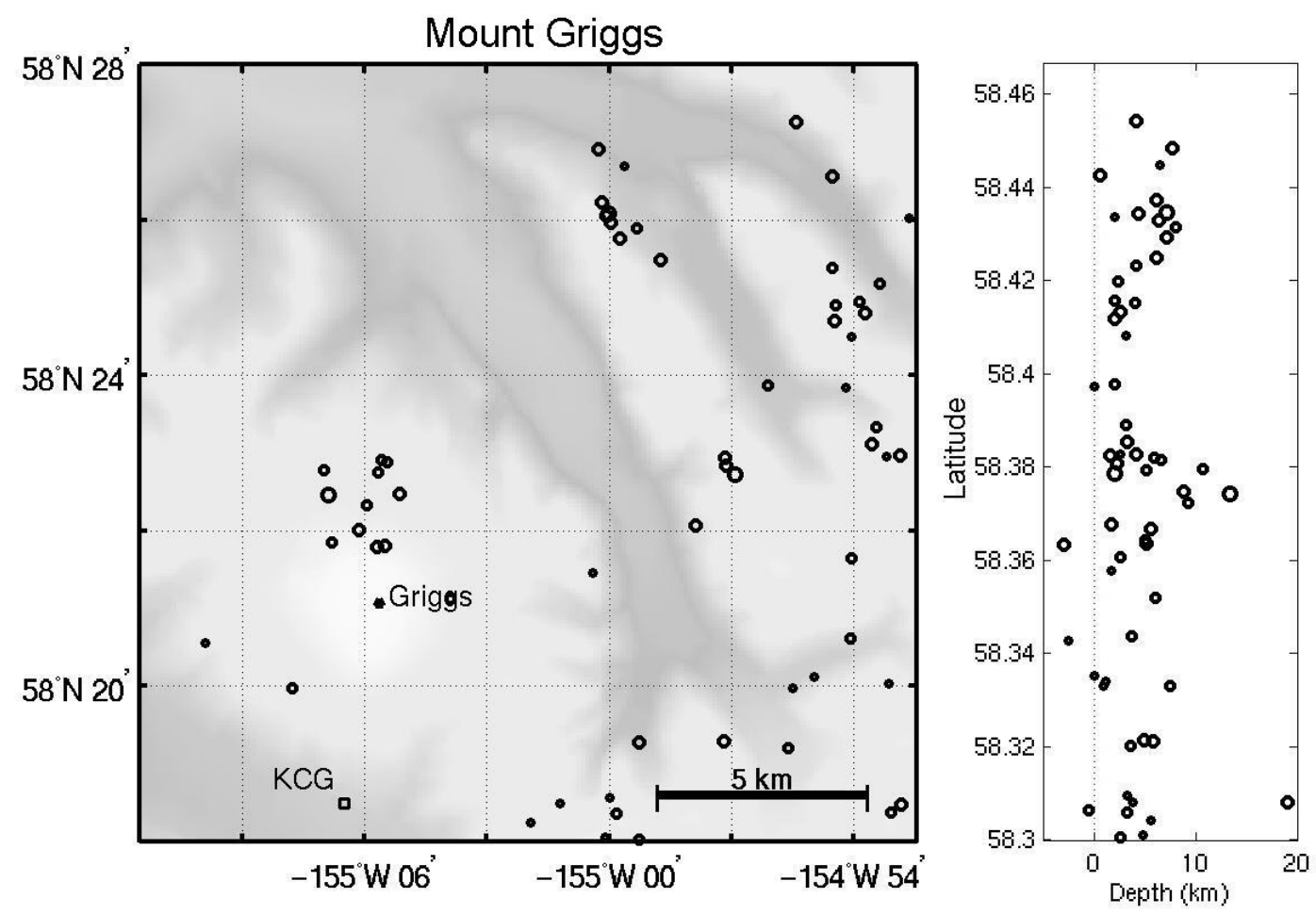

Mag. Symb. Size
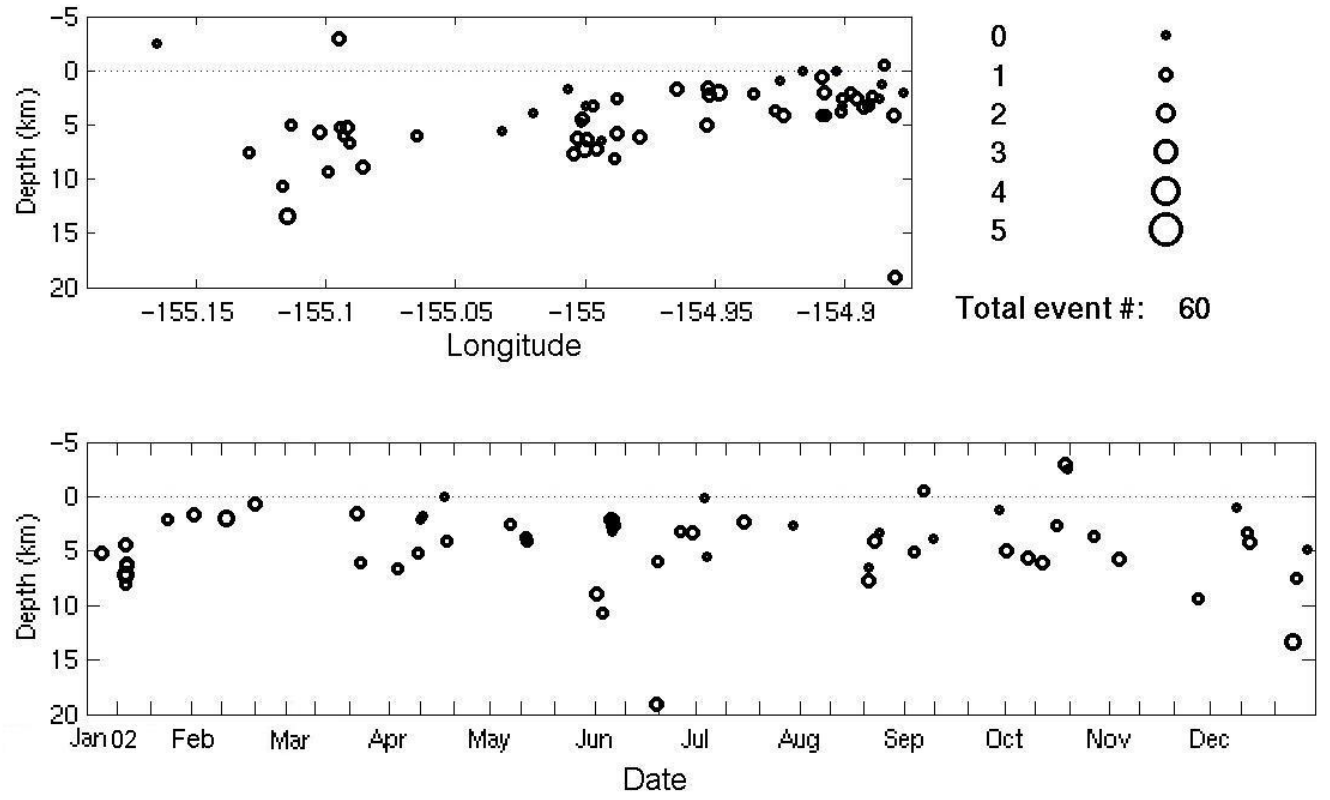

Figure A8. Summary plots of 60 earthquakes located near Mount Griggs in the Katmai volcanic group in 2002. Open circles scaled with magnitude show hypocenter locations shallower than $20 \mathrm{~km}$. Hypocenters with depths of $20 \mathrm{~km}$ and deeper are shown by open triangles scaled with magnitude. Seismic stations are shown by open squares and labeled by station code. (See Appendix B for station information). Closed circles are used to show other points of interest. 

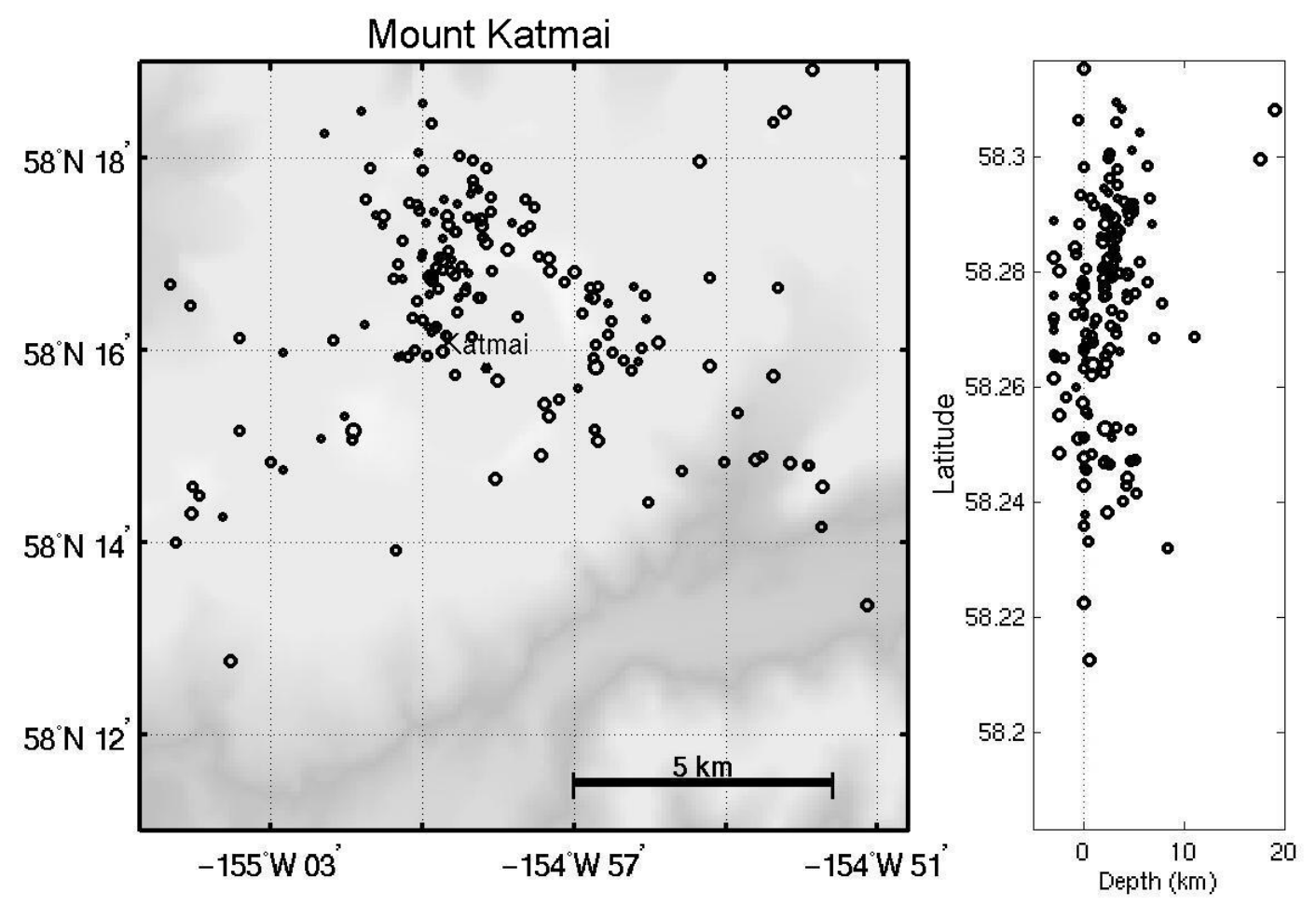

Mag. Symb. Size
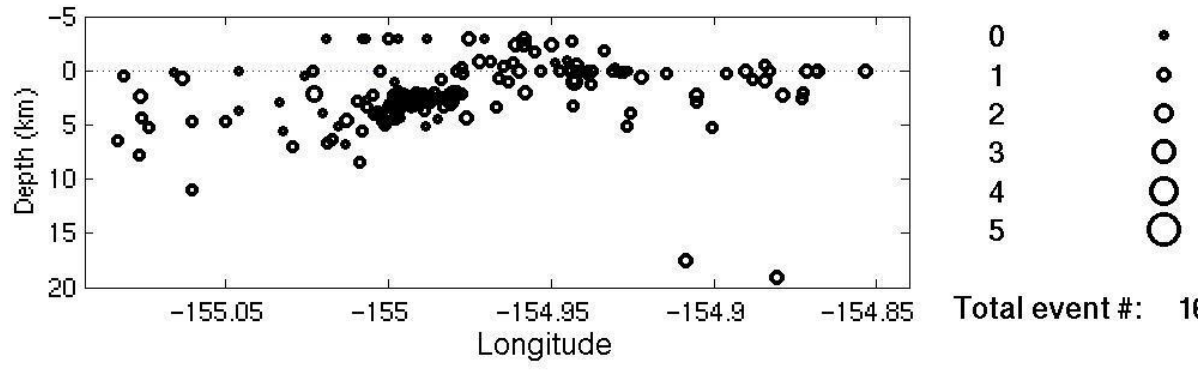

Total event \#: 164

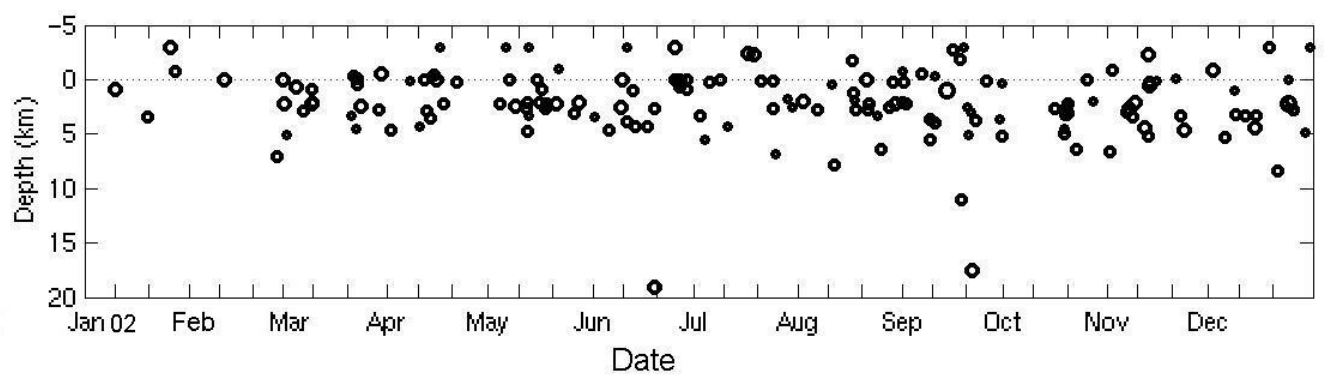

Figure A9. Summary plots of 164 earthquakes located near Mount Katmai in the Katmai volcanic group in 2002. Open circles scaled with magnitude show hypocenter locations shallower than $20 \mathrm{~km}$. Hypocenters with depths of $20 \mathrm{~km}$ and deeper are shown by open triangles scaled with magnitude. Seismic stations are shown by open squares and labeled by station code. (See Appendix B for station information). Closed circles are used to show other points of interest. 


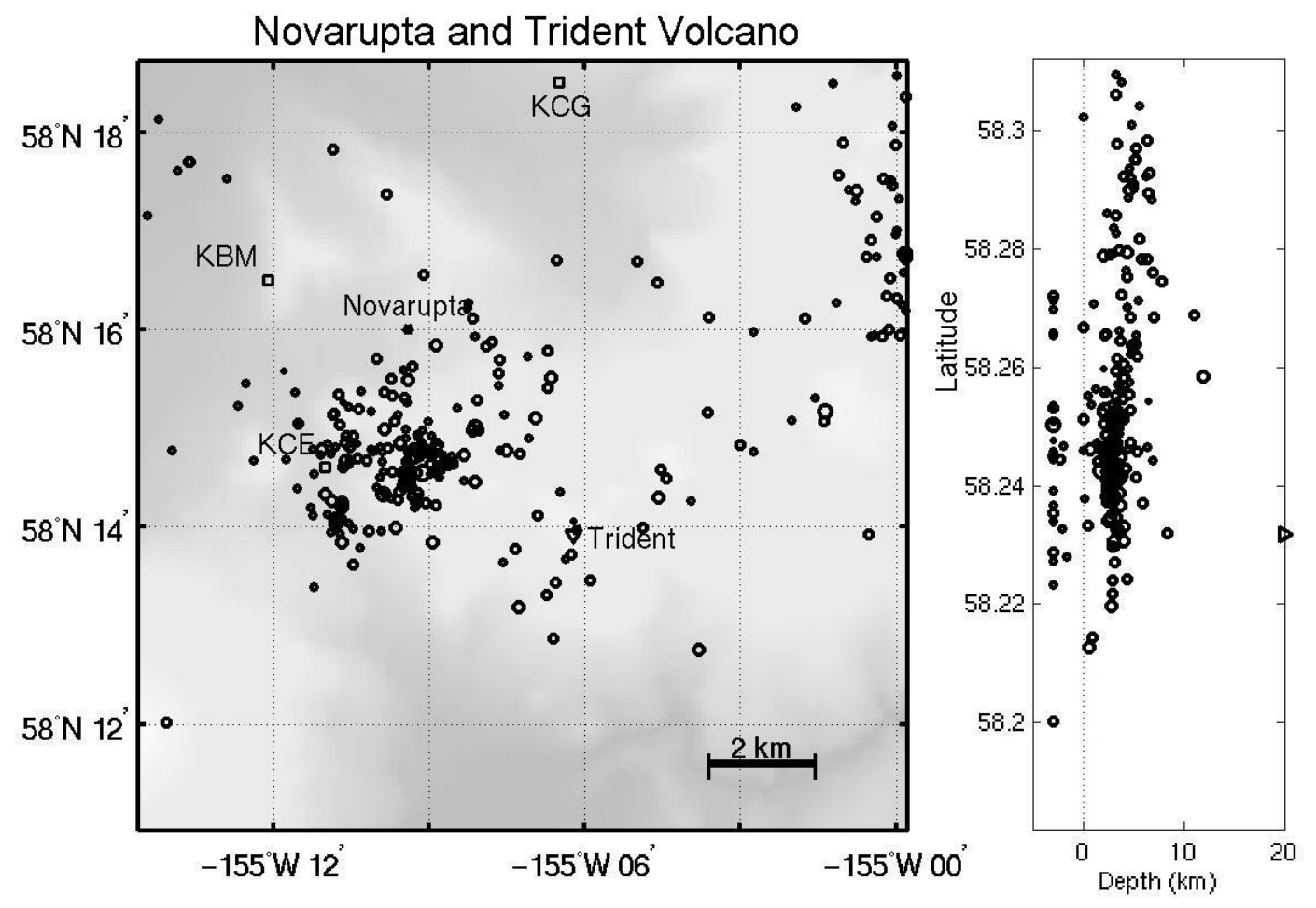

Mag. Symb. Size

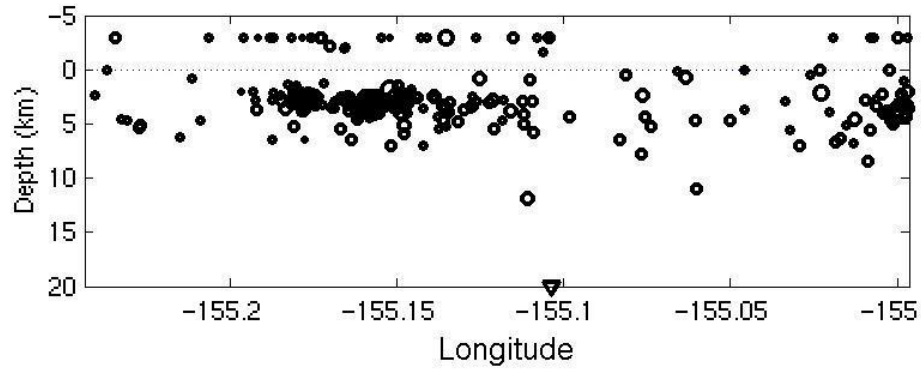

$0 \quad-$

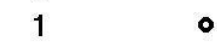

20

30

$\begin{array}{lll}4 & \stackrel{\bigcirc}{O}\end{array}$

Total event \#: 262

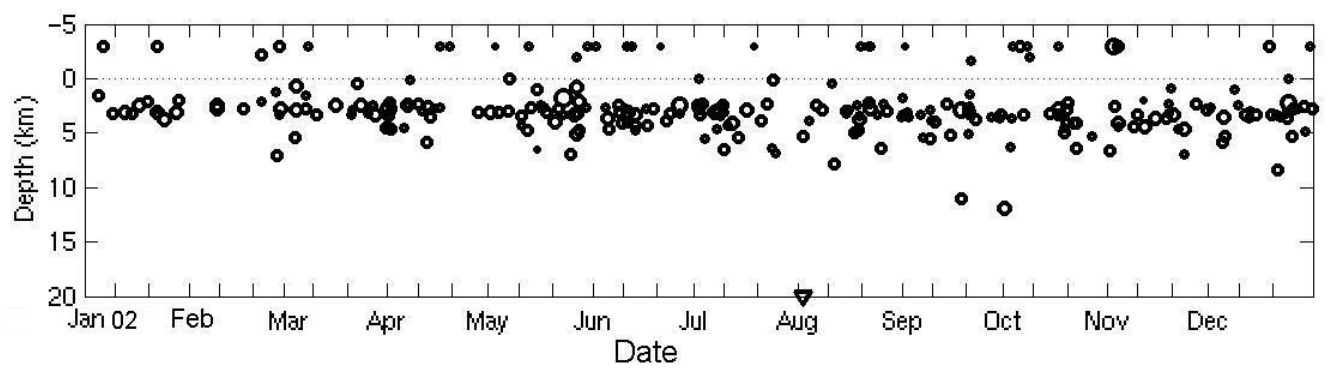

Figure A10. Summary plots of 262 earthquakes located near Novarupta and Trident Volcano in the Katmai volcanic group in 2002. Open circles scaled with magnitude show hypocenter locations shallower than $20 \mathrm{~km}$. Hypocenters with depths of $20 \mathrm{~km}$ and deeper are shown by open triangles scaled with magnitude. Seismic stations are shown by open squares and labeled by station code. (See Appendix B for station information). Closed circles are used to show other points of interest. 


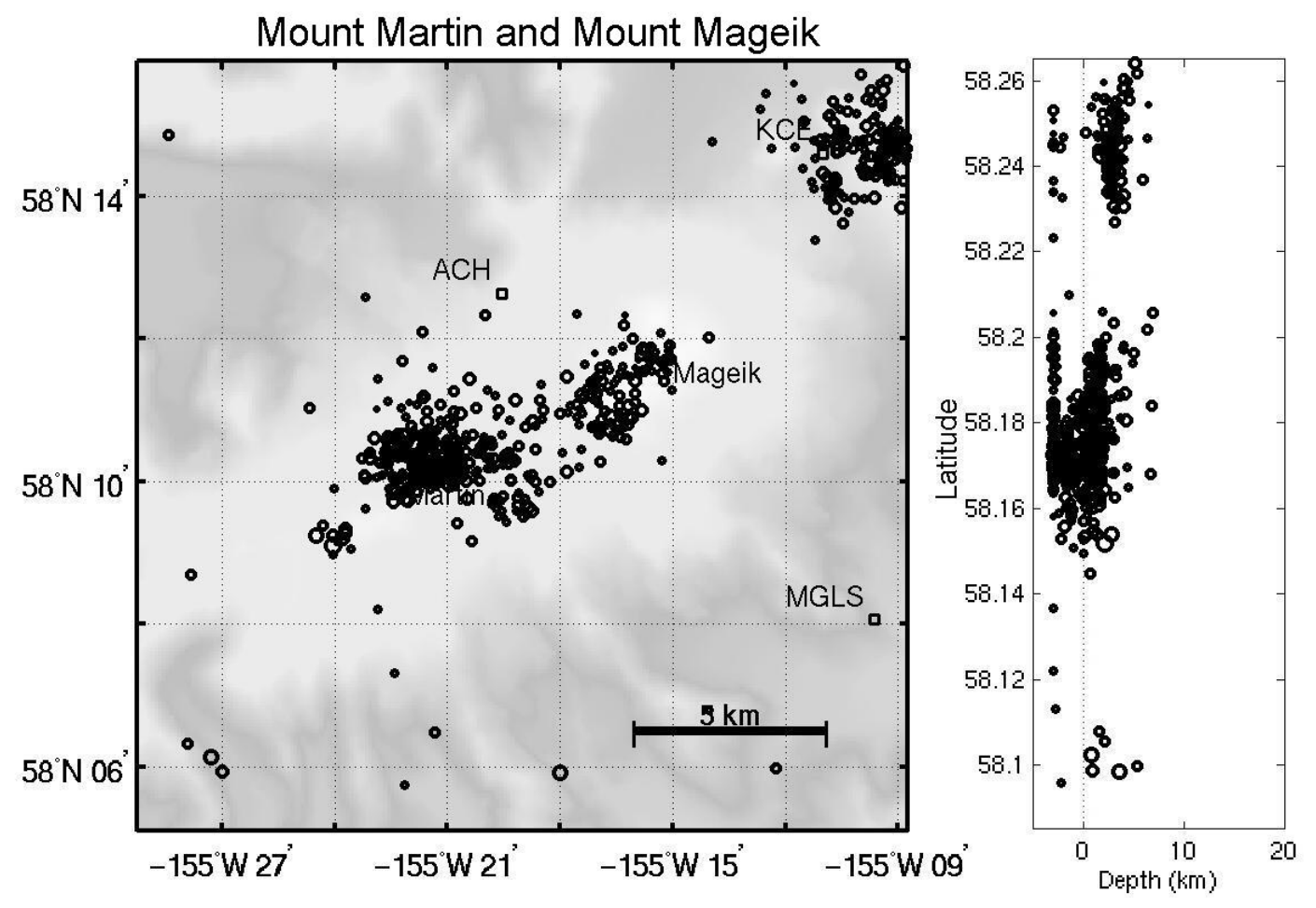

Mag. Symb. Size
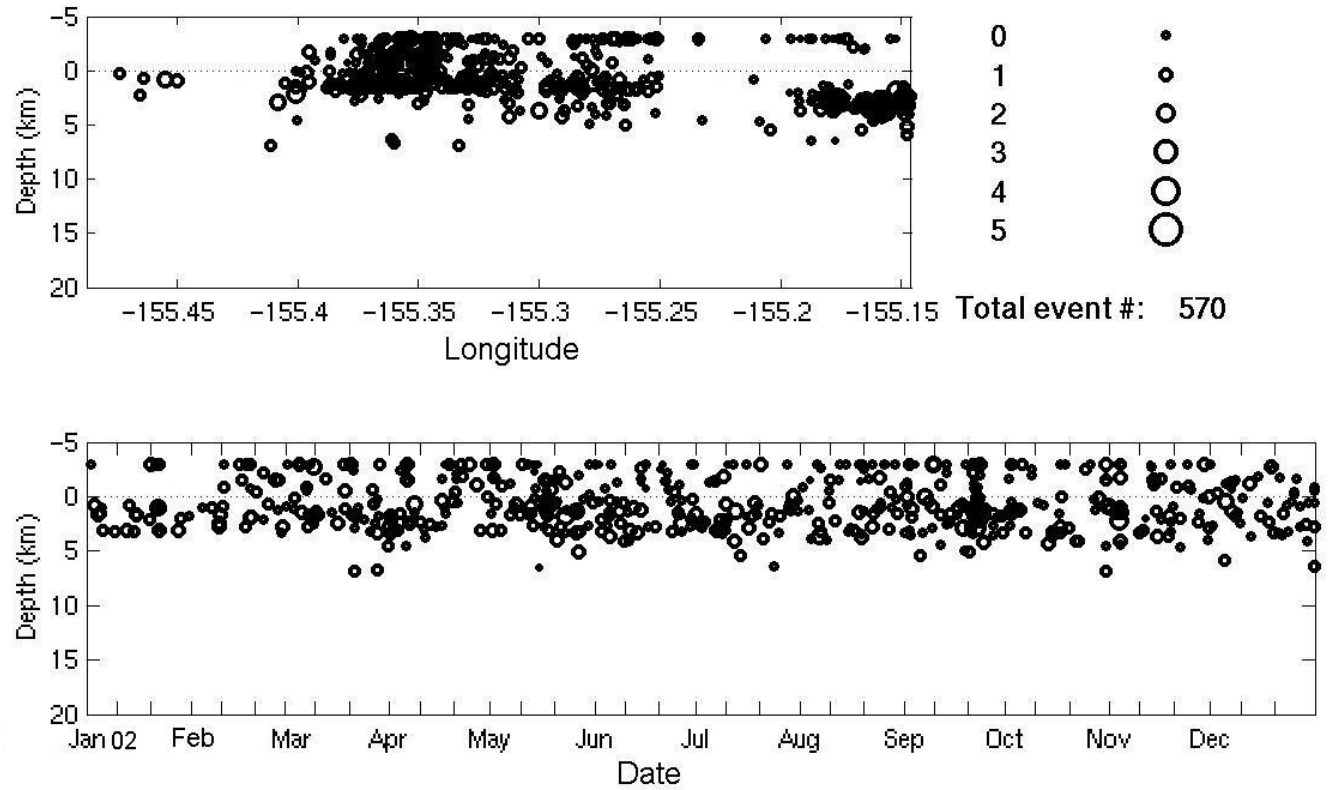

Figure A11. Summary plots of 570 earthquakes located near Mount Mageik and Mount Martin in the Katmai volcanic group in 2002. Open circles scaled with magnitude show hypocenter locations shallower than $20 \mathrm{~km}$. Hypocenters with depths of $20 \mathrm{~km}$ and deeper are shown by open triangles scaled with magnitude. Seismic stations are shown by open squares and labeled by station code. (See Appendix B for station information). Closed circles are used to show other points of interest. 

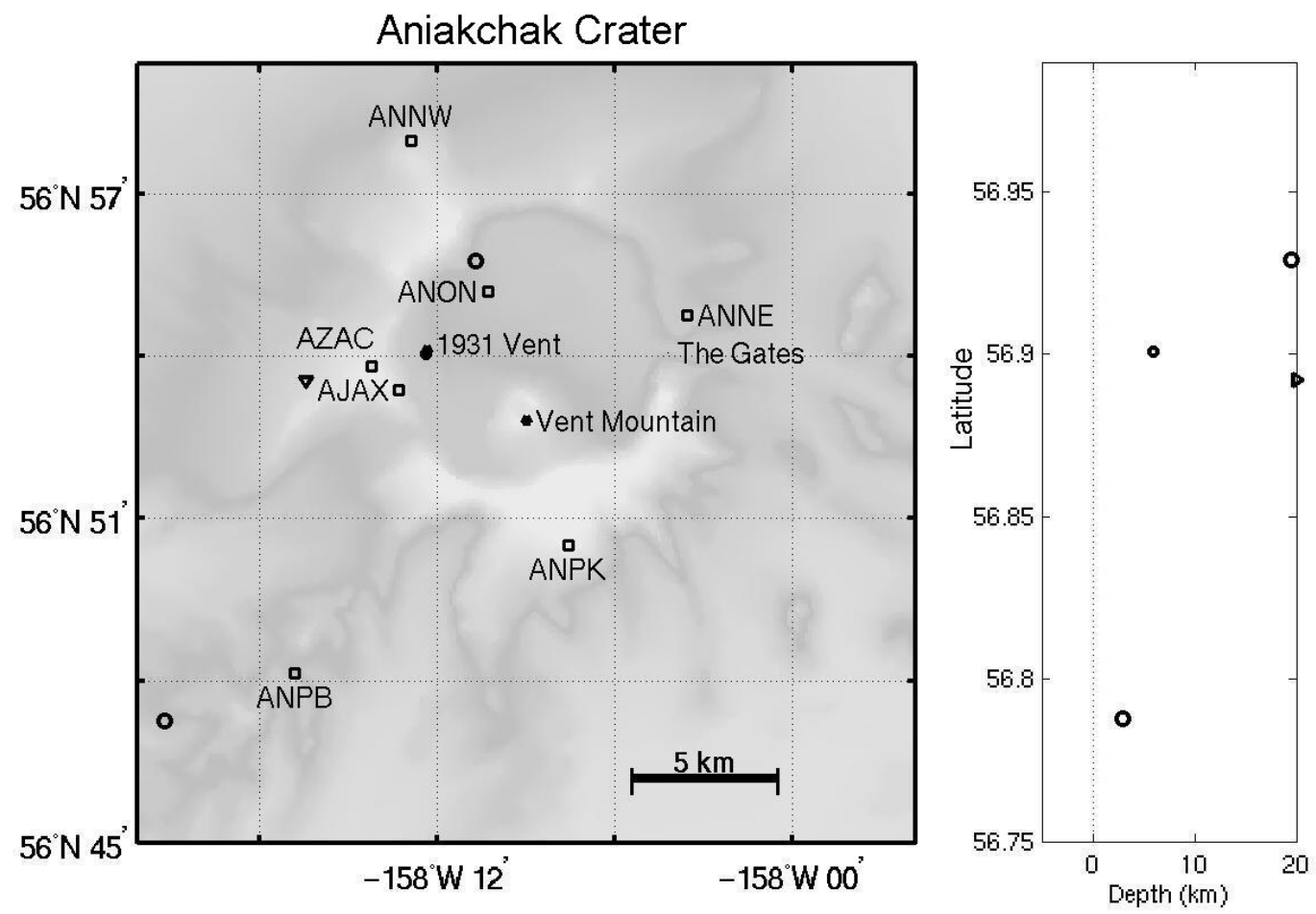

Mag. Symb. Size
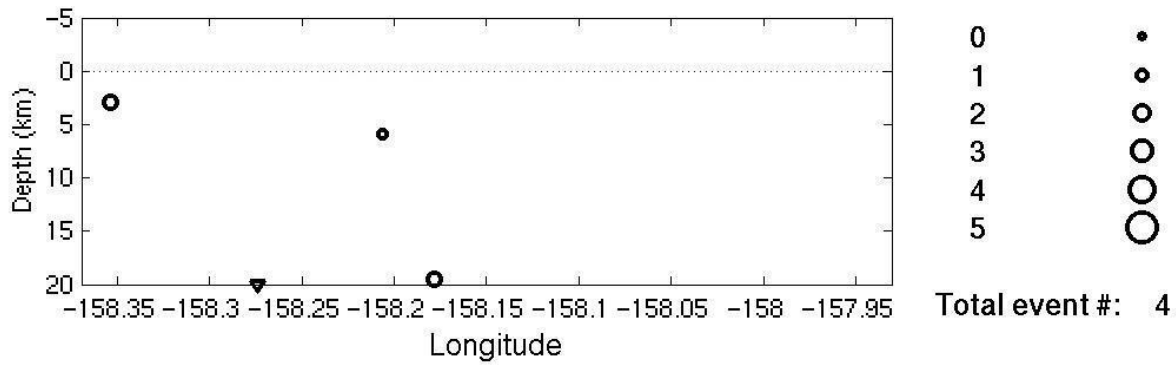

Total event \#: 4

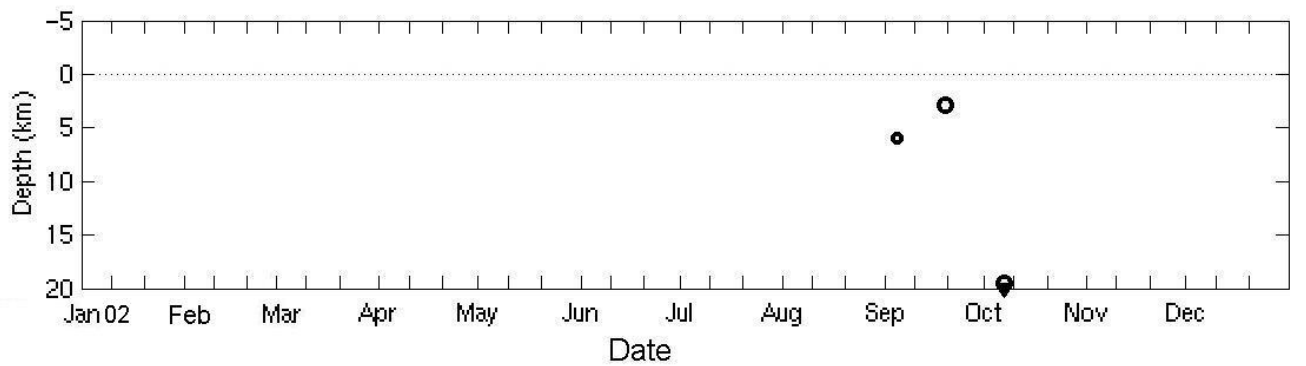

Figure A12. Summary plots of four earthquakes located near Aniakchak Crater in 2002. Open circles scaled with magnitude show hypocenter locations shallower than $20 \mathrm{~km}$. Hypocenters with depths of $20 \mathrm{~km}$ and deeper are shown by open triangles scaled with magnitude. Seismic stations are shown by open squares and labeled by station code. (See Appendix B for station information). Closed circles are used to show other points of interest. The Aniakchak subnetwork was repaired in the summer of 2002, and contributed to the apparent lack of seismicity in the first half of 2002. 

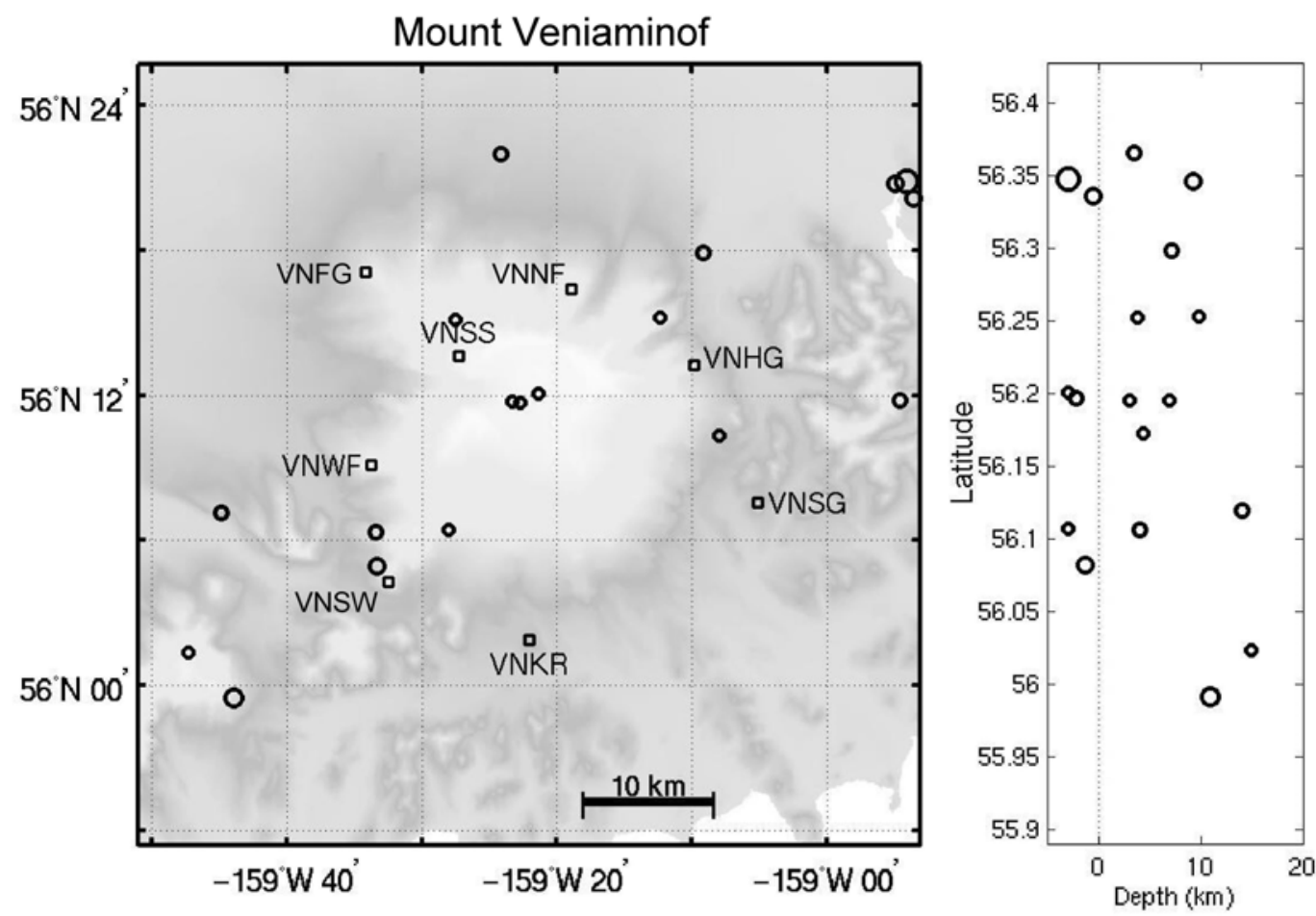

Mag. Symb. Size
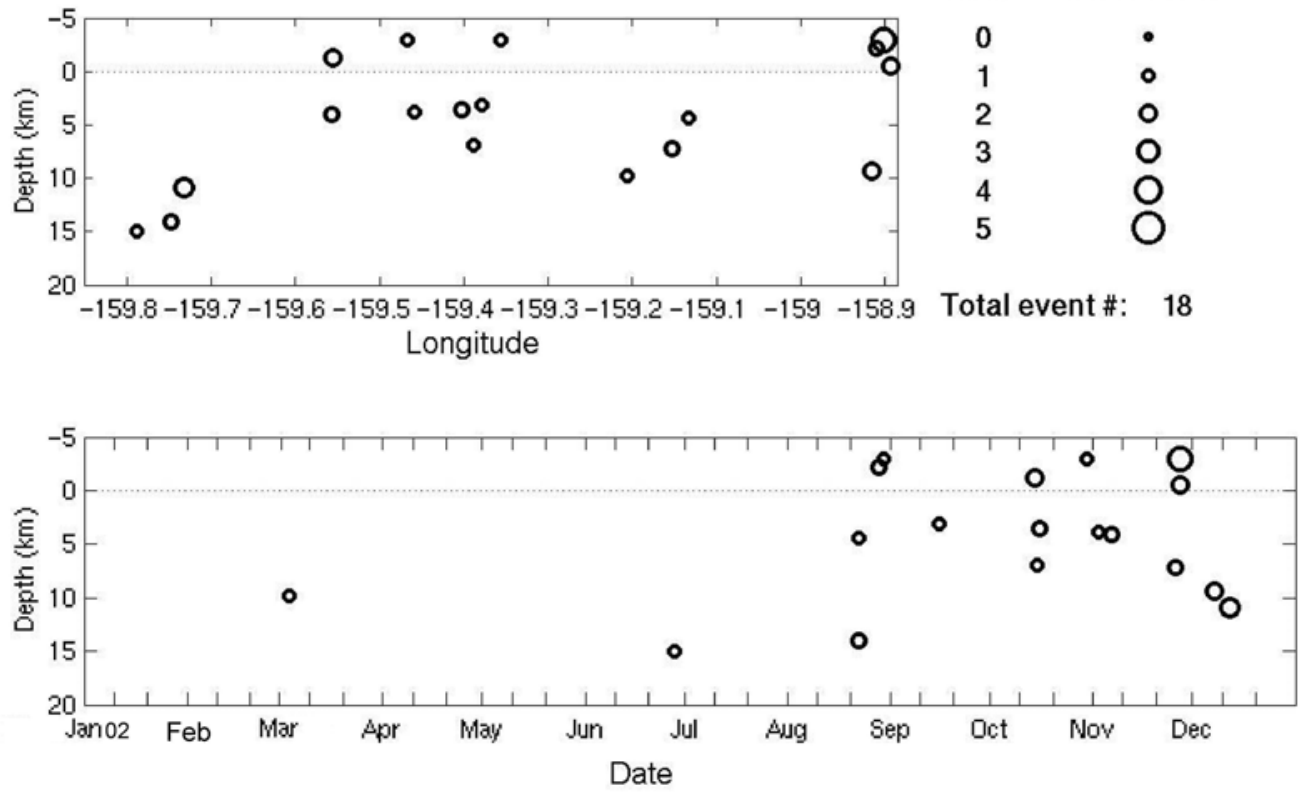

Figure A13. Summary plots of 18 earthquakes located near Mount Veniaminof in 2002. Open circles scaled with magnitude show hypocenter locations shallower than $20 \mathrm{~km}$. Hypocenters with depths of $20 \mathrm{~km}$ and deeper are shown by open triangles scaled with magnitude. Seismic stations are shown by open squares and labeled by station code. (See Appendix B for station information). Closed circles are used to show other points of interest. The Veniaminof sub-network telemetry was permanently installed in the summer of 2002. 

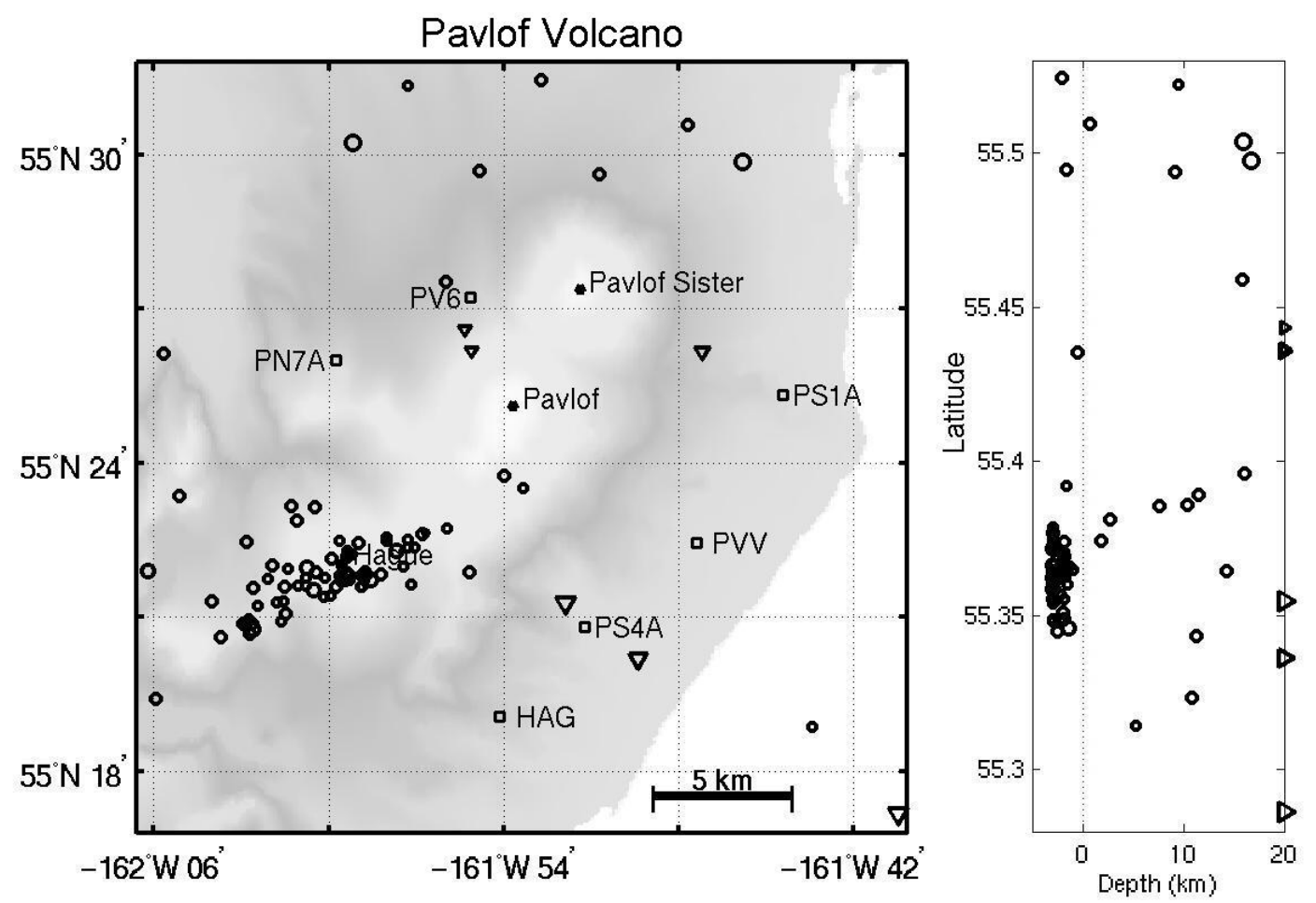

Mag. Symb. Size
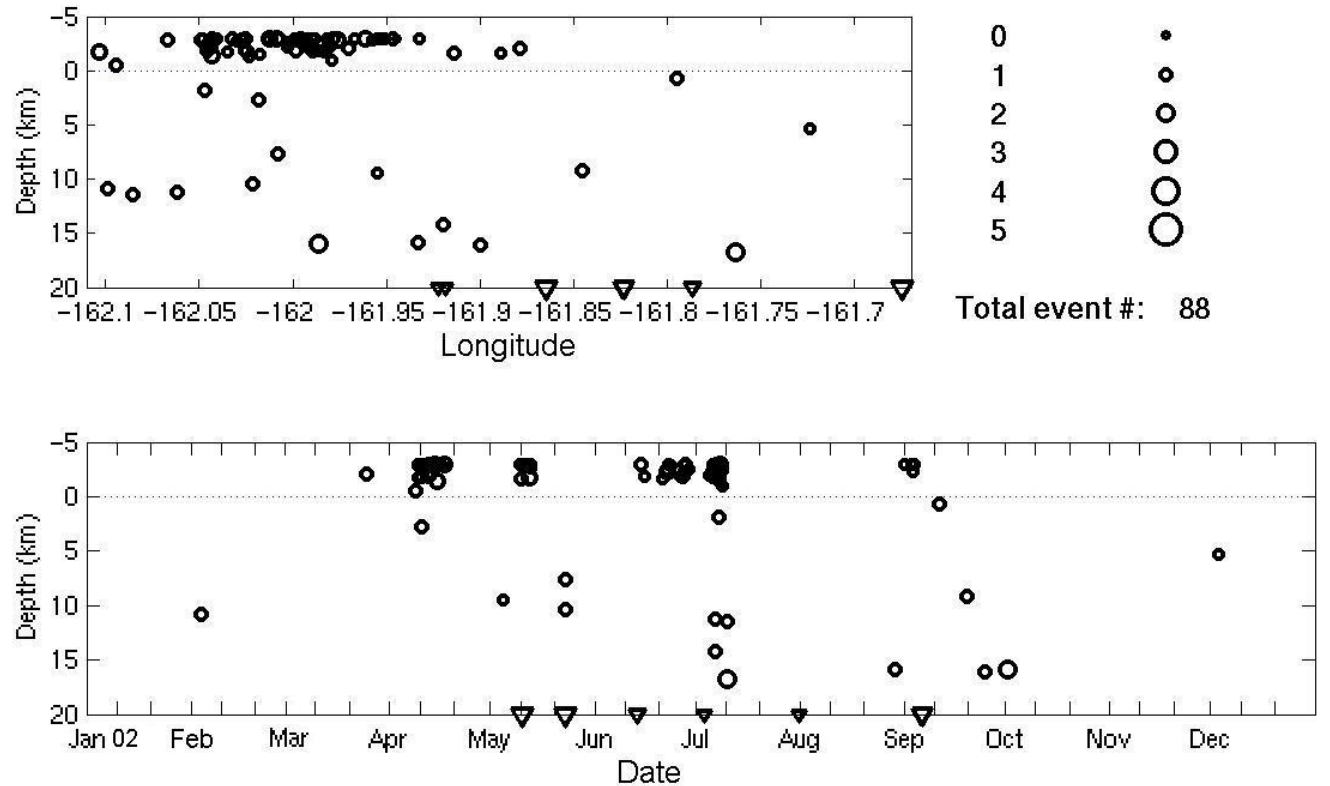

Figure A14. Summary plots of 88 earthquakes located near Pavlof Volcano in 2002. Open circles scaled with magnitude show hypocenter locations shallower than $20 \mathrm{~km}$. Hypocenters with depths of $20 \mathrm{~km}$ and deeper are shown by open triangles scaled with magnitude. Seismic stations are shown by open squares and labeled by station code. (See Appendix B for station information). Closed circles are used to show other points of interest. 

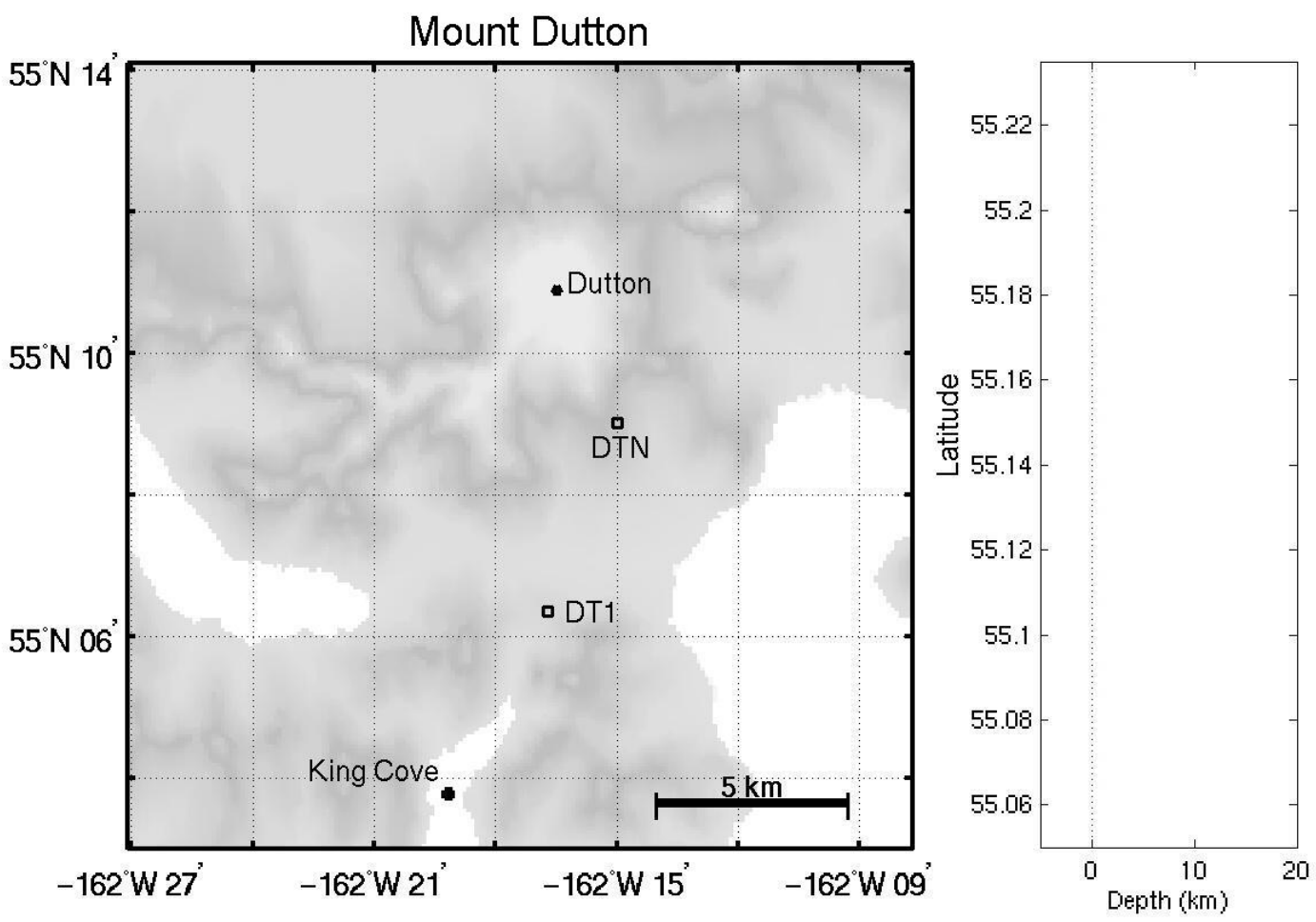

Mag. Symb. Size
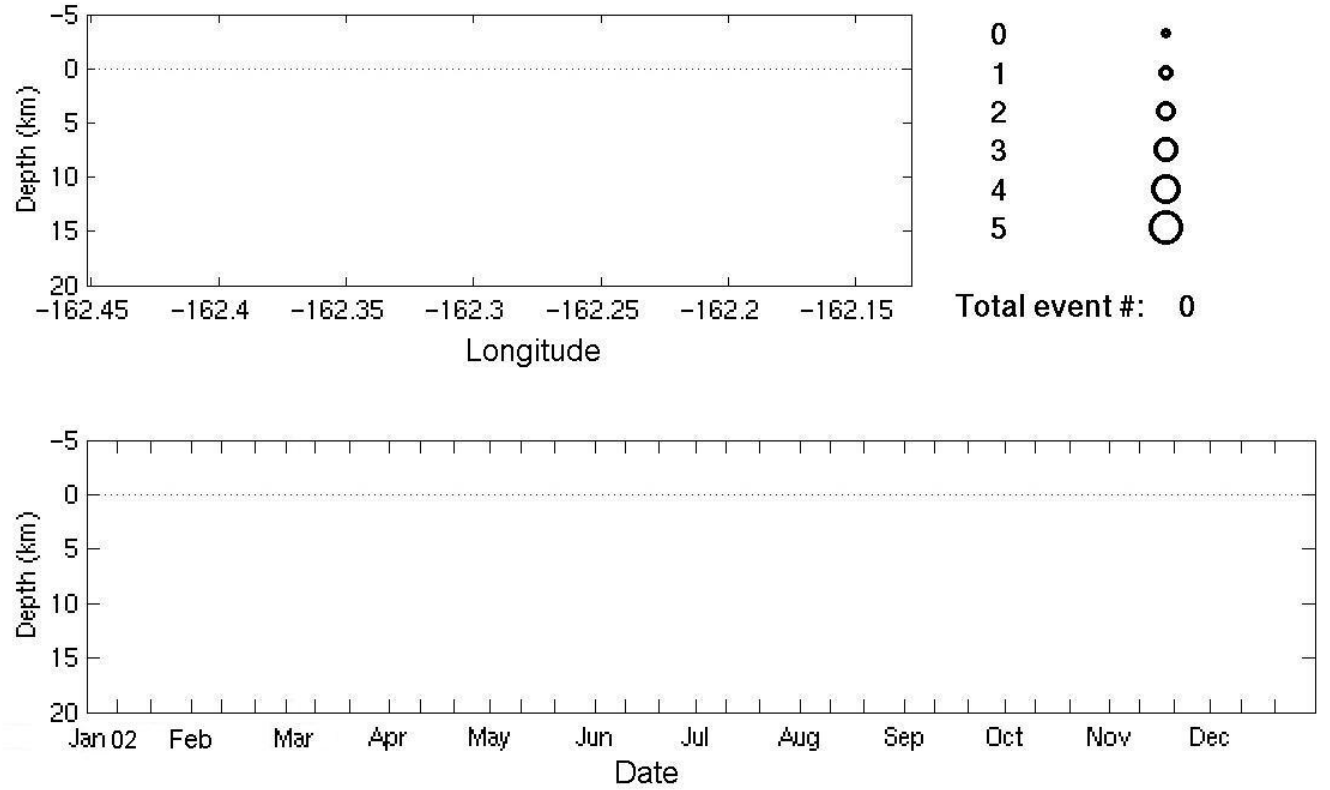

Figure A15. This summary plot shows no earthquakes located near Mount Dutton in 2002. Seismic stations DTN and DT1 were down throughout the year, contributing to the lack of detected seismicity. Seismic stations are shown by open squares and labeled by station code. (See Appendix B for station information). Closed circles are used to show other points of interest. 

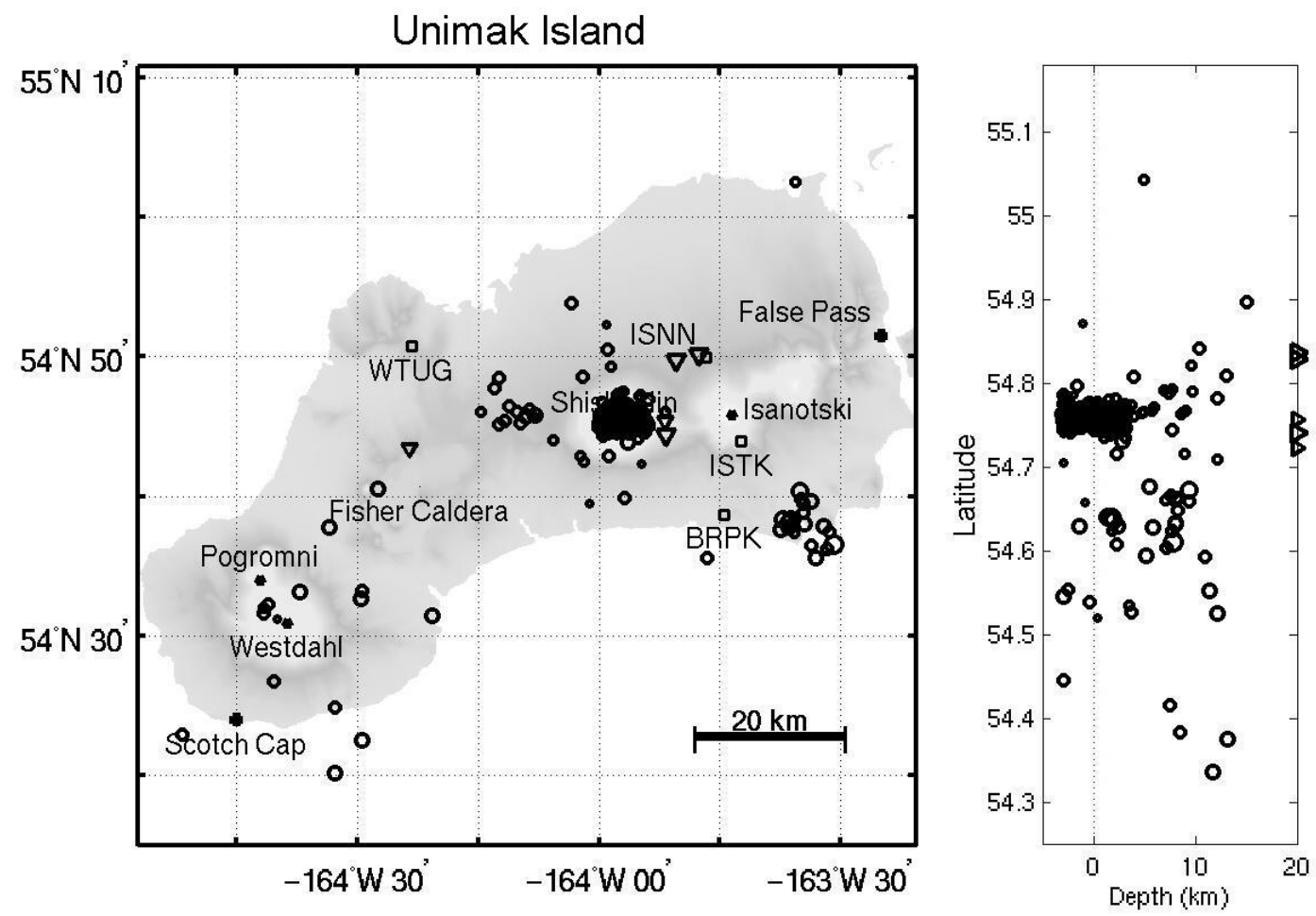

Mag. Symb. Size
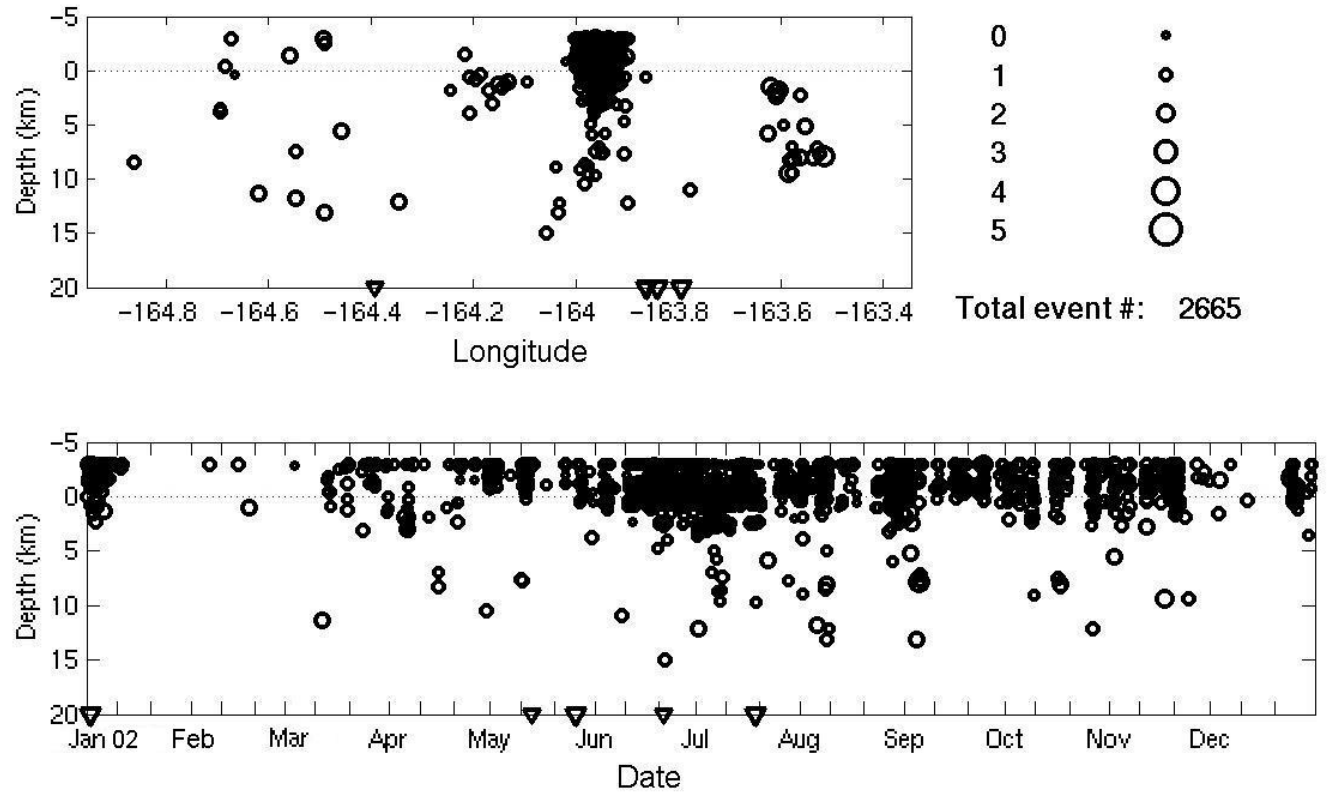

Figure A16. Summary plots of 2665 earthquakes located near Unimak Island in 2002. Open circles scaled with magnitude show hypocenter locations shallower than $20 \mathrm{~km}$. Hypocenters with depths of $20 \mathrm{~km}$ and deeper are shown by open triangles scaled with magnitude. Seismic stations are shown by open squares and labeled by station code. (See Appendix B for station information). Closed circles are used to show other points of interest. 

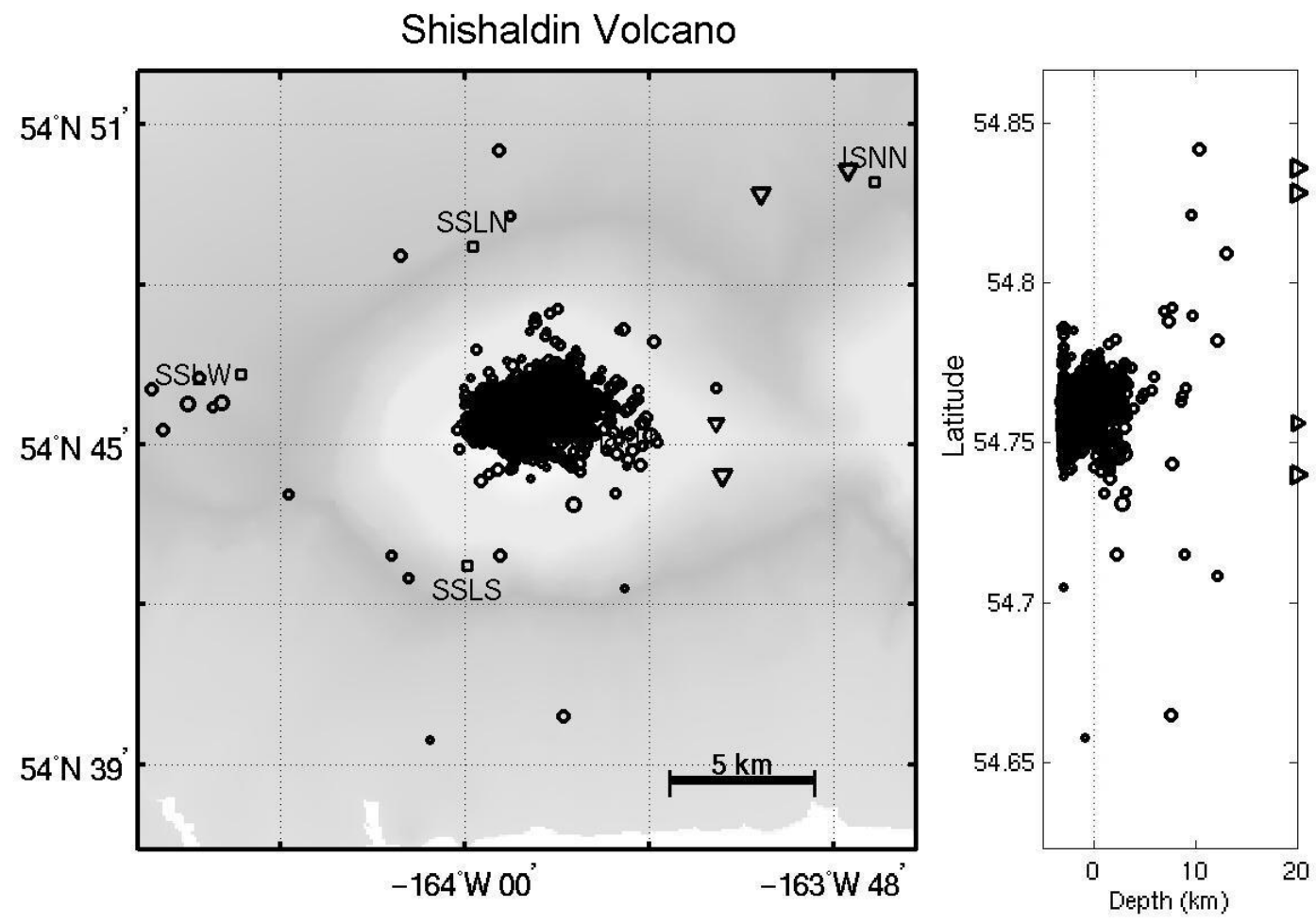

Mag. Symb. Size
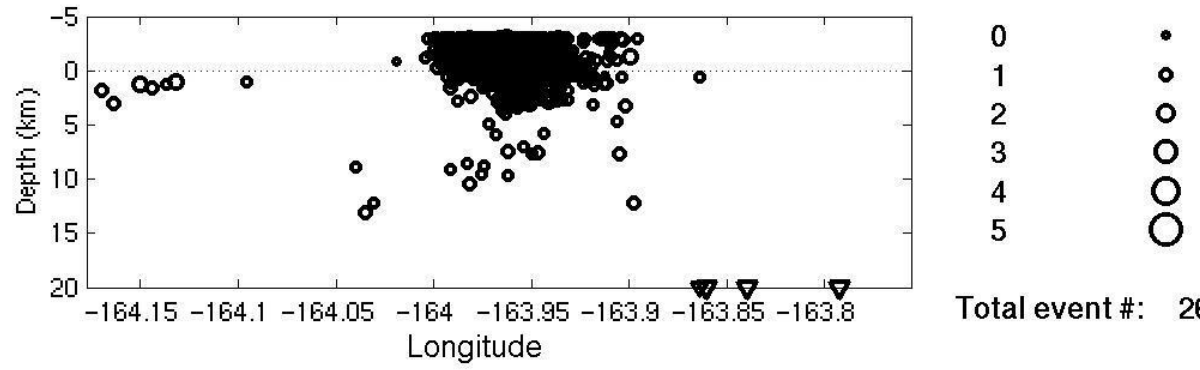

Total event \#: 2620

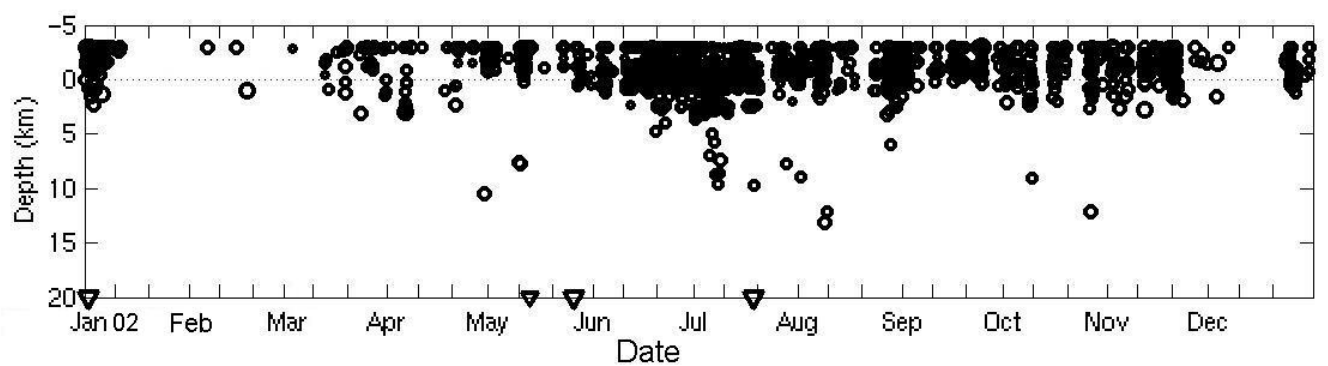

Figure A17. Summary plots of 2620 earthquakes located near Shishaldin Volcano in 2002. Open circles scaled with magnitude show hypocenter locations shallower than 20 $\mathrm{km}$. Hypocenters with depths of $20 \mathrm{~km}$ and deeper are shown by open triangles scaled with magnitude. Seismic stations are shown by open squares and labeled by station code. (See Appendix B for station information). Closed circles are used to show other points of interest. 

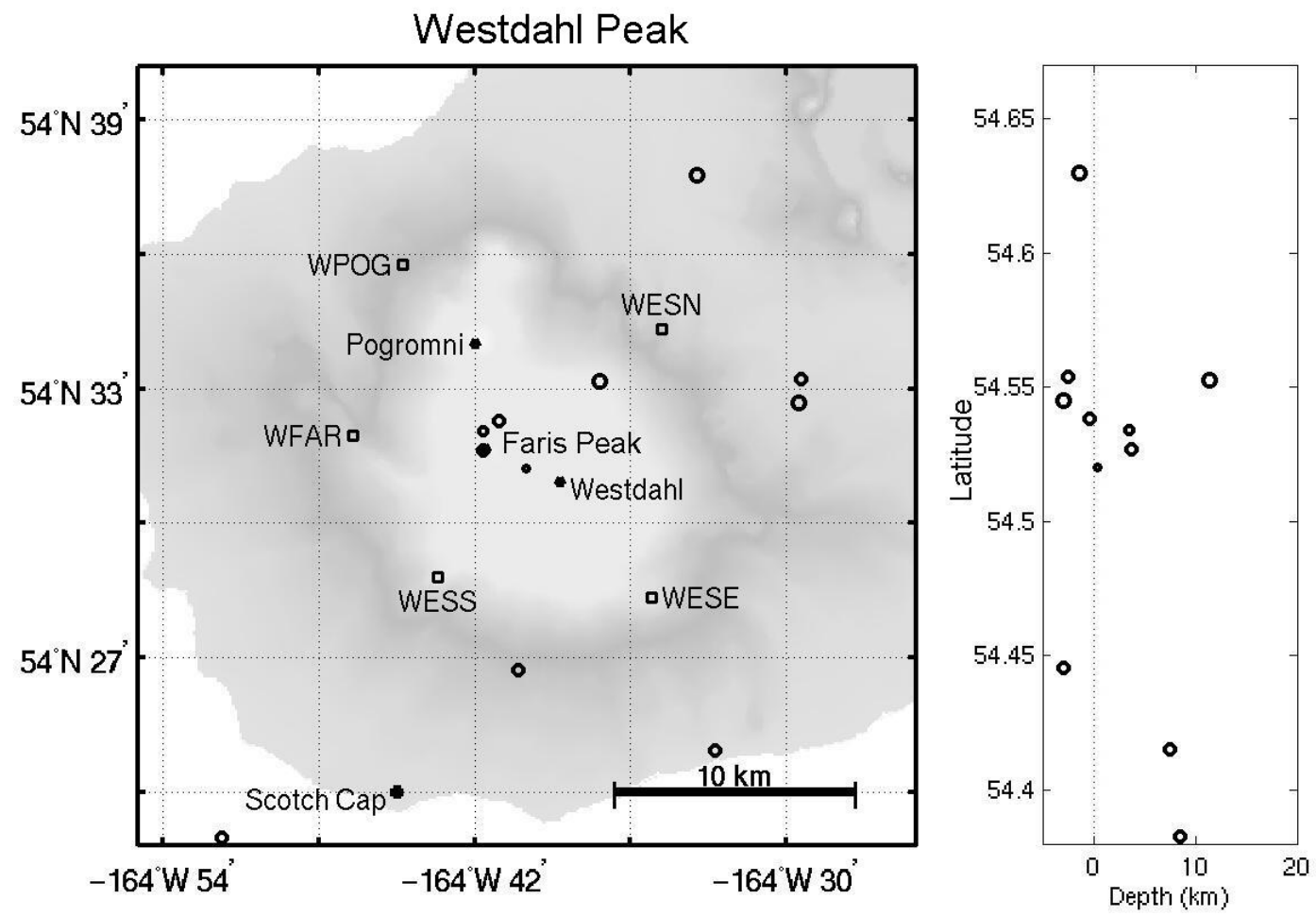

Mag. Symb. Size
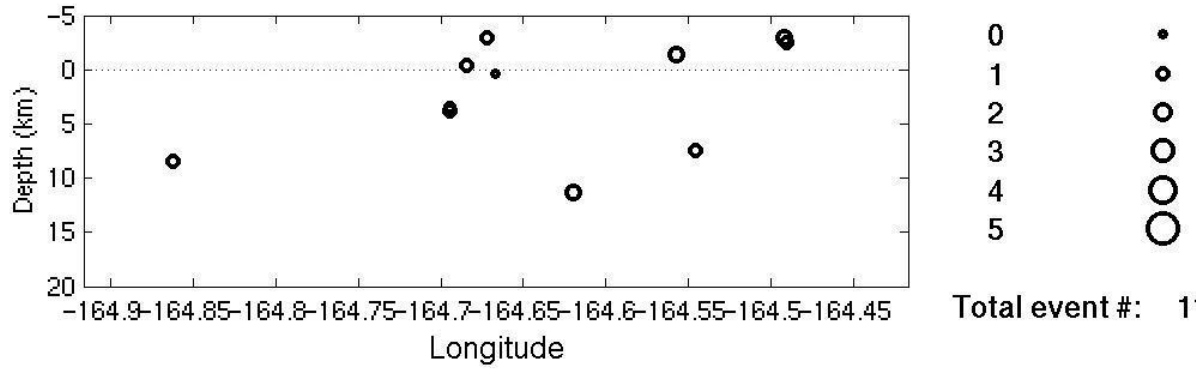

Total event \#: 11

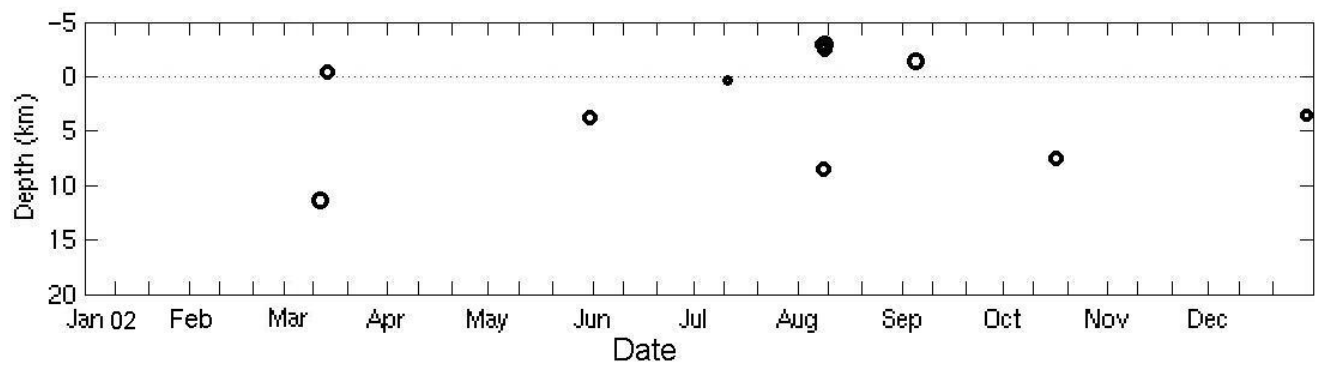

Figure A18. Summary plots of 11 earthquakes located near Westdahl Peak in 2002. Open circles scaled with magnitude show hypocenter locations shallower than $20 \mathrm{~km}$. Hypocenters with depths of $20 \mathrm{~km}$ and deeper are shown by open triangles scaled with magnitude. Seismic stations are shown by open squares and labeled by station code. (See Appendix B for station information). Closed circles are used to show other points of interest. 

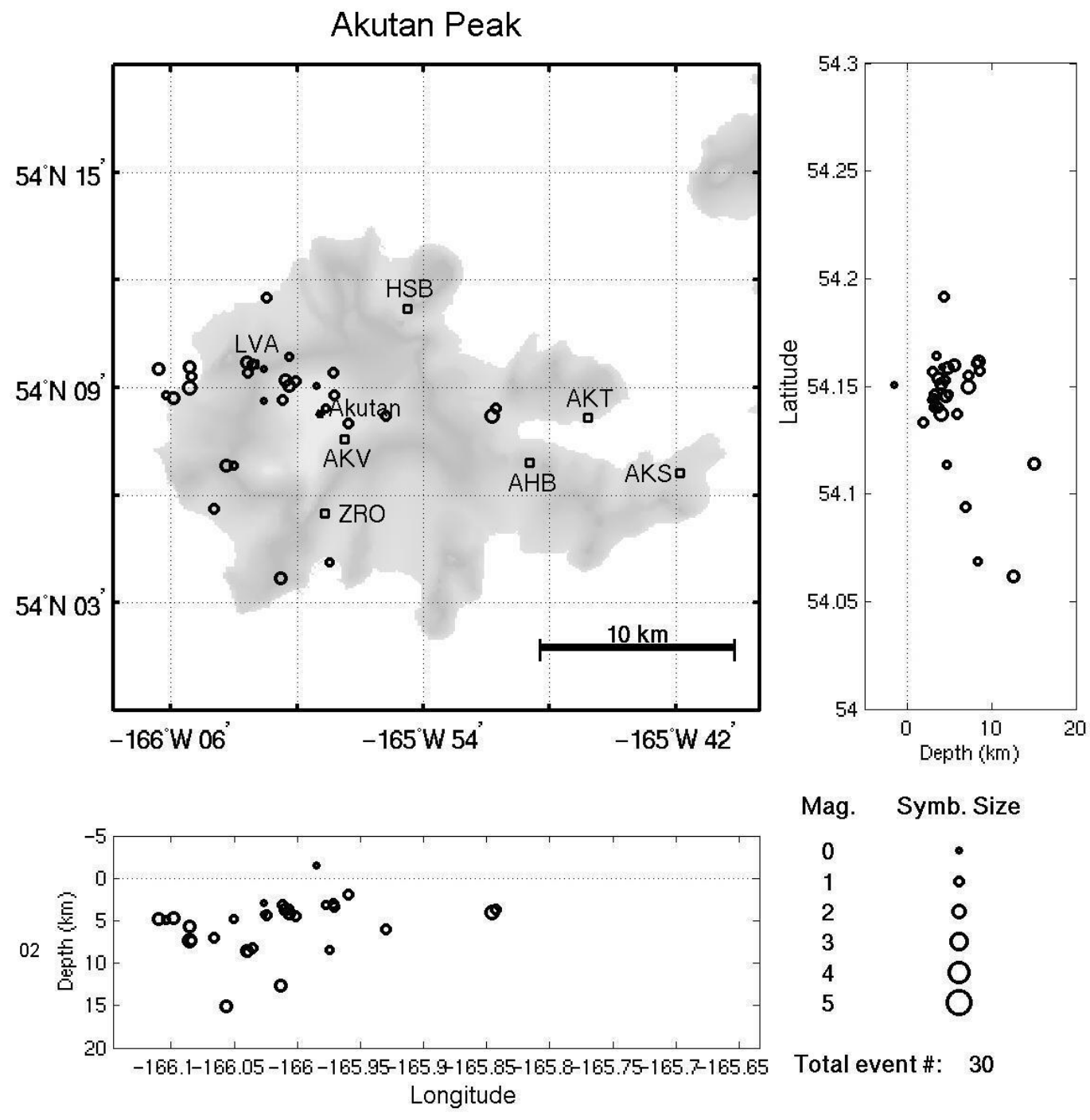

Mag. Symb. Size
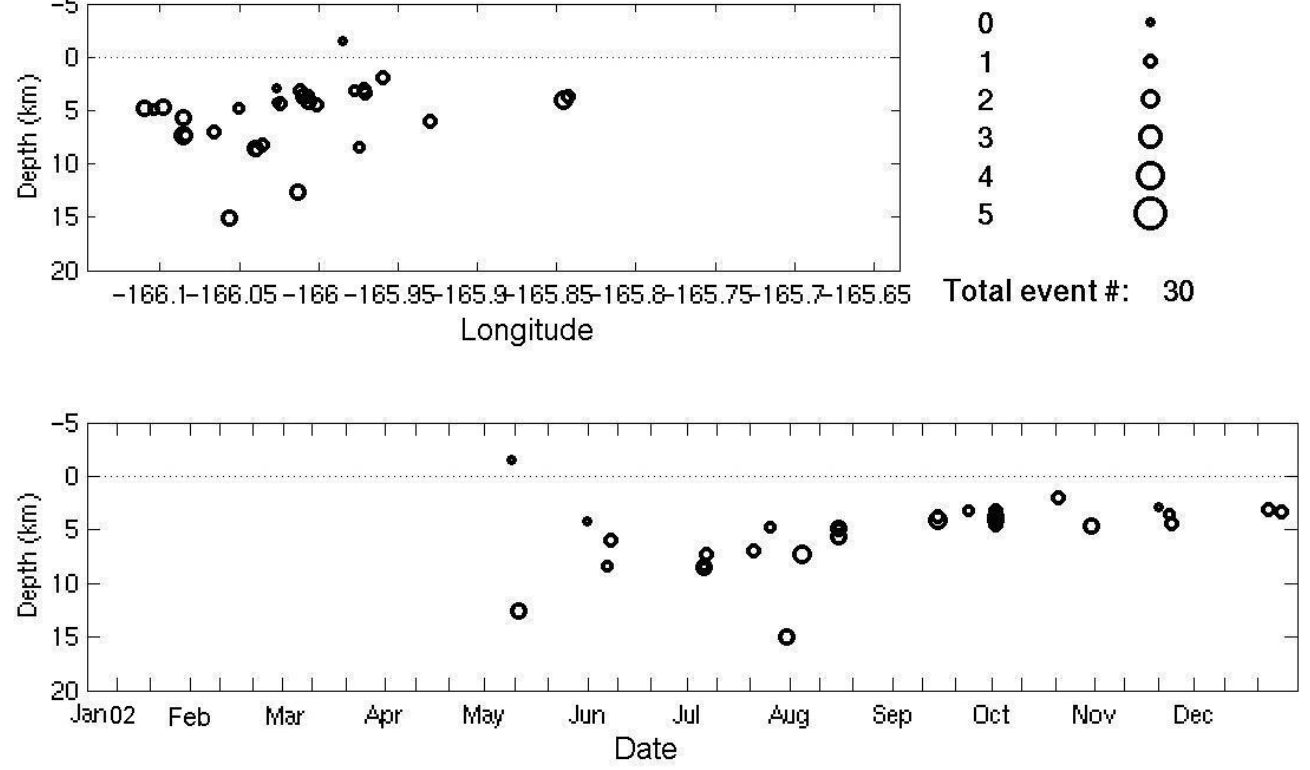

Figure A19. Summary plots of 30 earthquakes located near Akutan Peak in 2002. Open circles scaled with magnitude show hypocenter locations shallower than $20 \mathrm{~km}$. Hypocenters with depths of $20 \mathrm{~km}$ and deeper are shown by open triangles scaled with magnitude. Seismic stations are shown by open squares and labeled by station code. (See Appendix B for station information). Closed circles are used to show other points of interest. The apparent increase in seismic activity is an artifact of station outages before May 2002. 


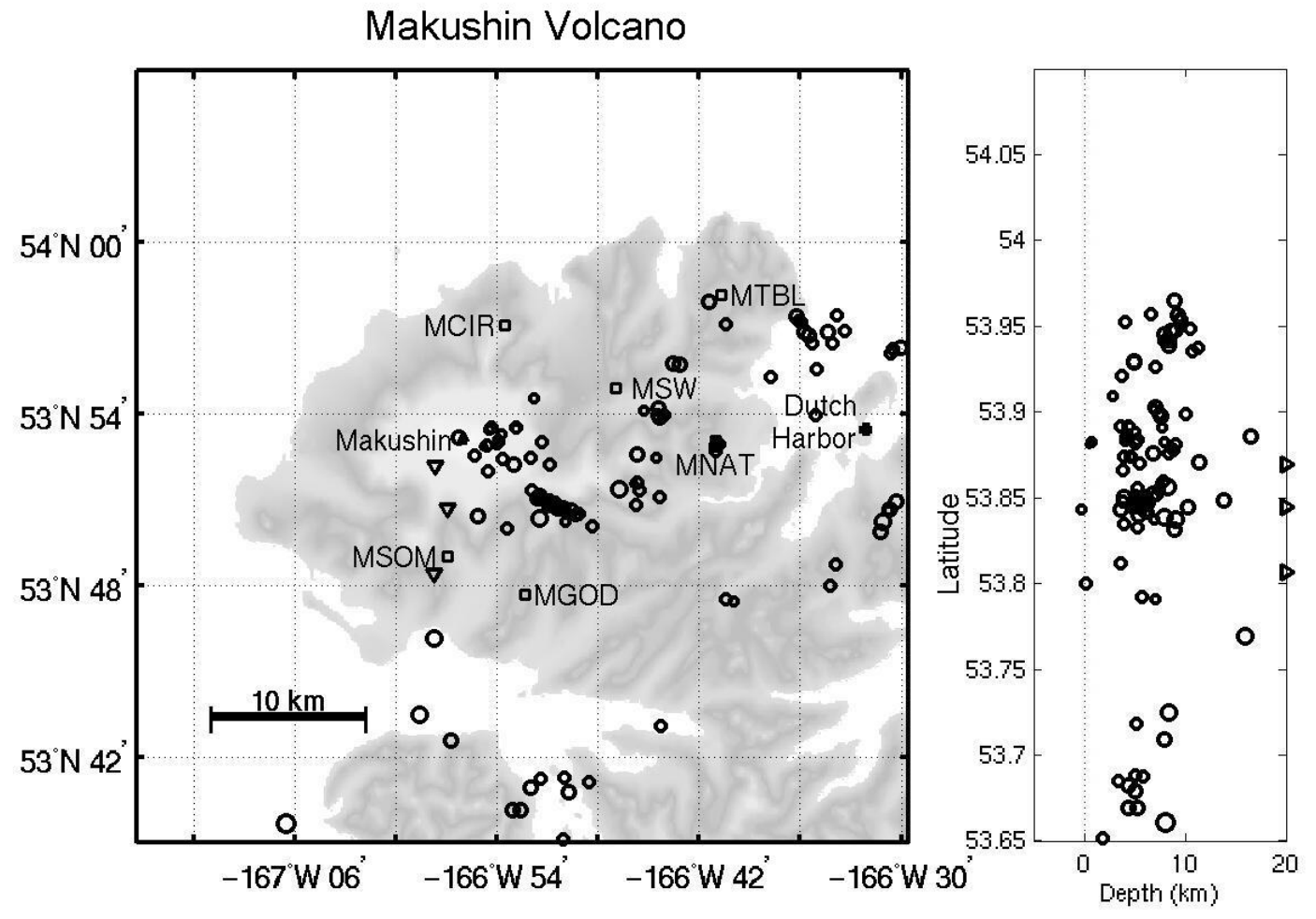

Mag. Symb. Size
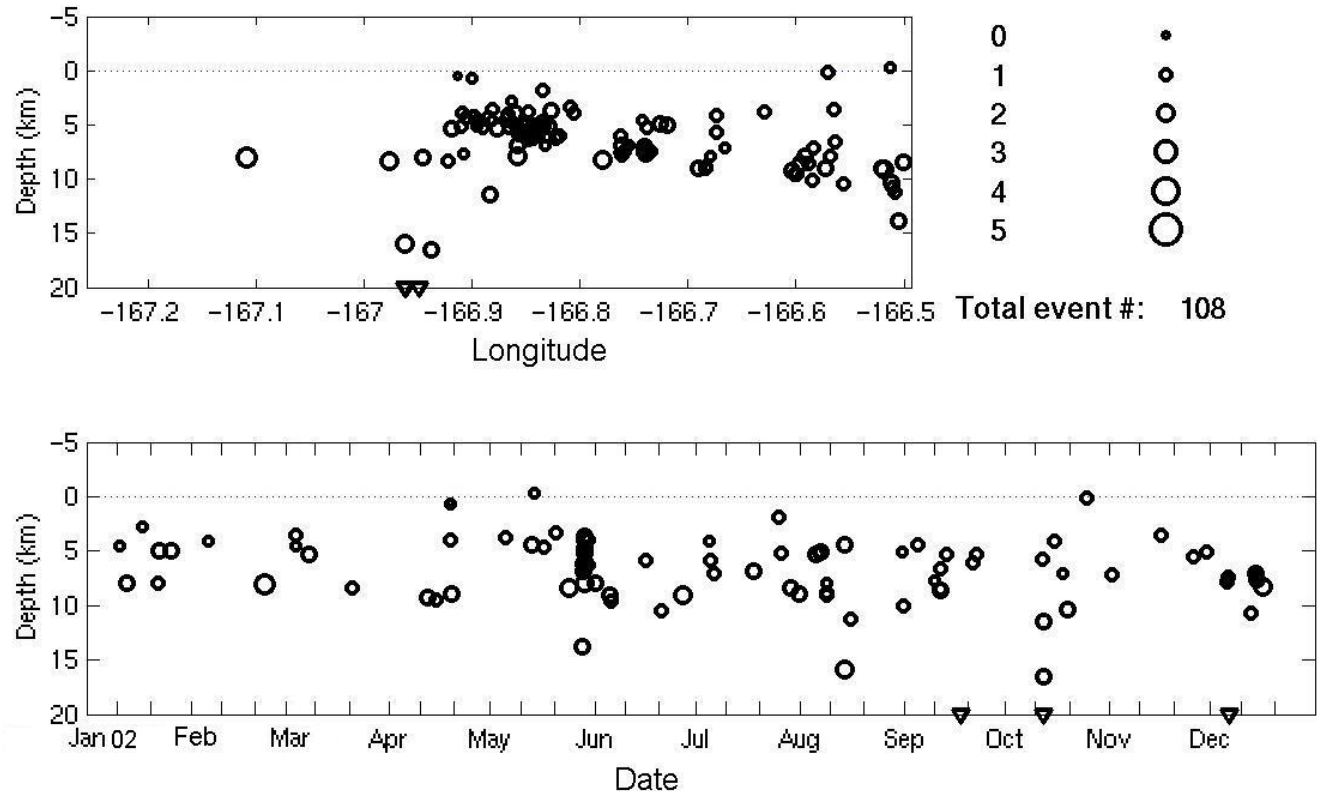

Figure A20. Summary plots of 108 earthquakes located near Makushin Volcano in 2002. Open circles scaled with magnitude show hypocenter locations shallower than $20 \mathrm{~km}$. Hypocenters with depths of $20 \mathrm{~km}$ and deeper are shown by open triangles scaled with magnitude. Seismic stations are shown by open squares and labeled by station code. (See Appendix B for station information). Closed circles are used to show other points of interest. 

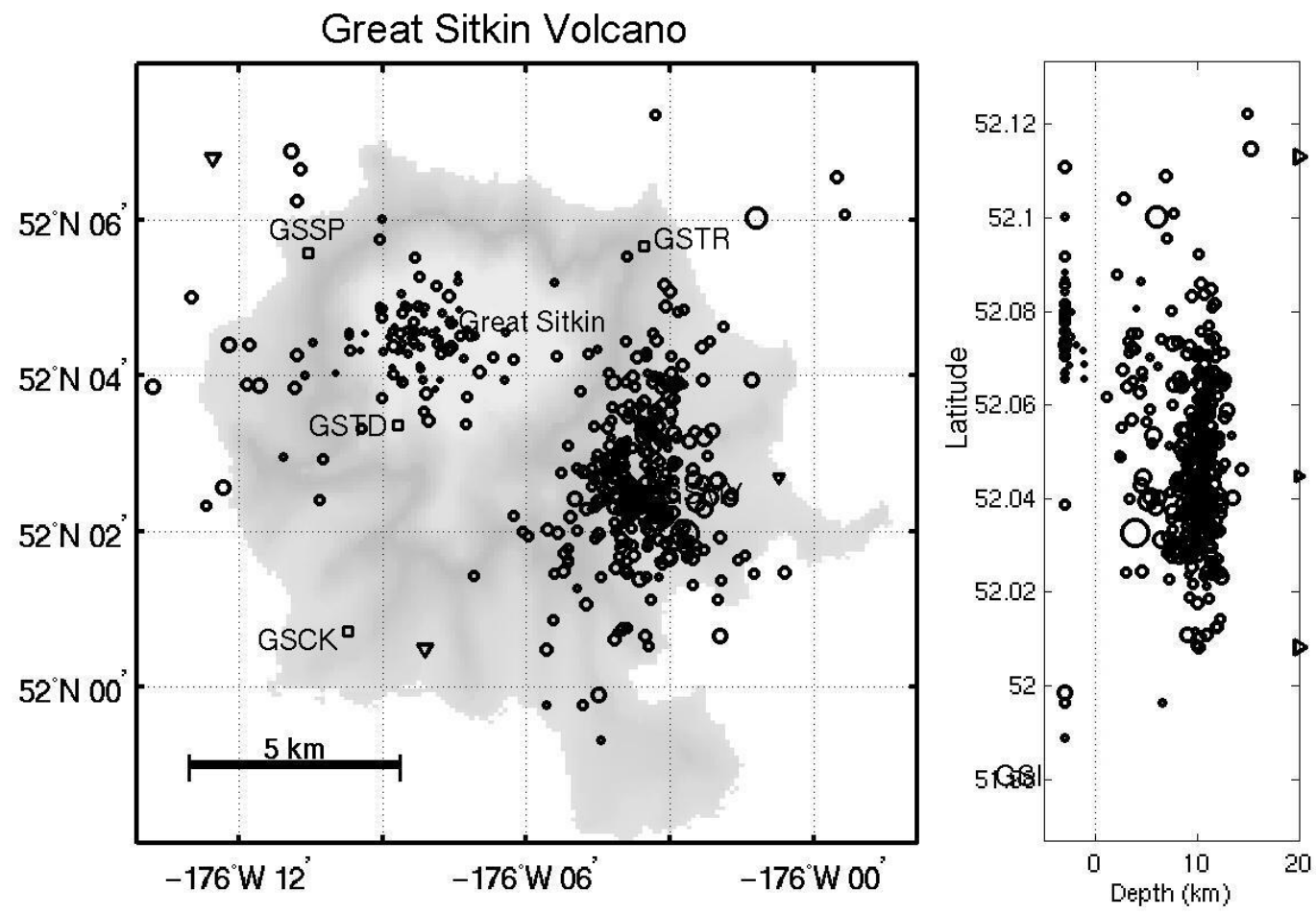

Mag. Symb. Size
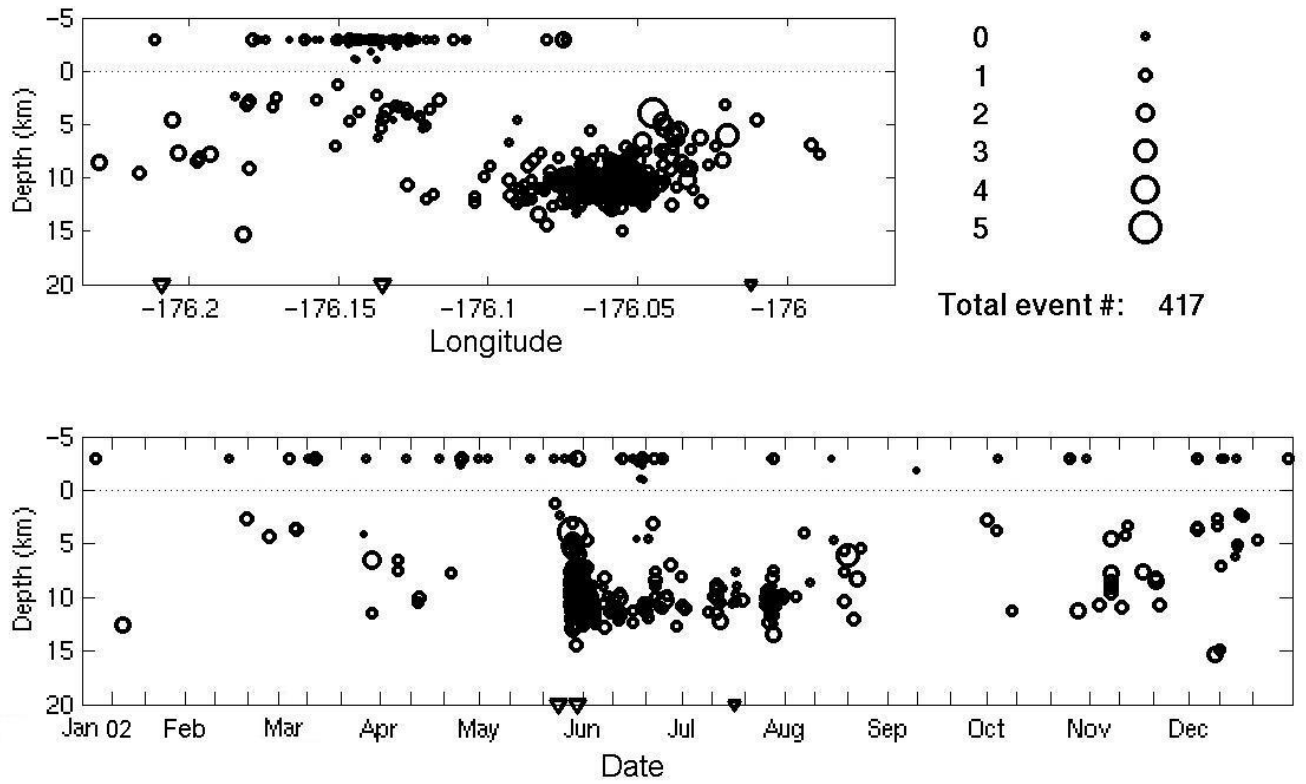

Figure A21. Summary plots of 417 earthquakes located near Great Sitkin Volcano in 2002. Open circles scaled with magnitude show hypocenter locations shallower than 20 $\mathrm{km}$. Hypocenters with depths of $20 \mathrm{~km}$ and deeper are shown by open triangles scaled with magnitude. Seismic stations are shown by open squares and labeled by station code. (See Appendix B for station information). Closed circles are used to show other points of interest. The earthquakes swarm 5-10 km southeast of Great Sitkin Volcano in May and June accounts for $65 \%$ of all earthquakes in the Great Sitkin Island region. 

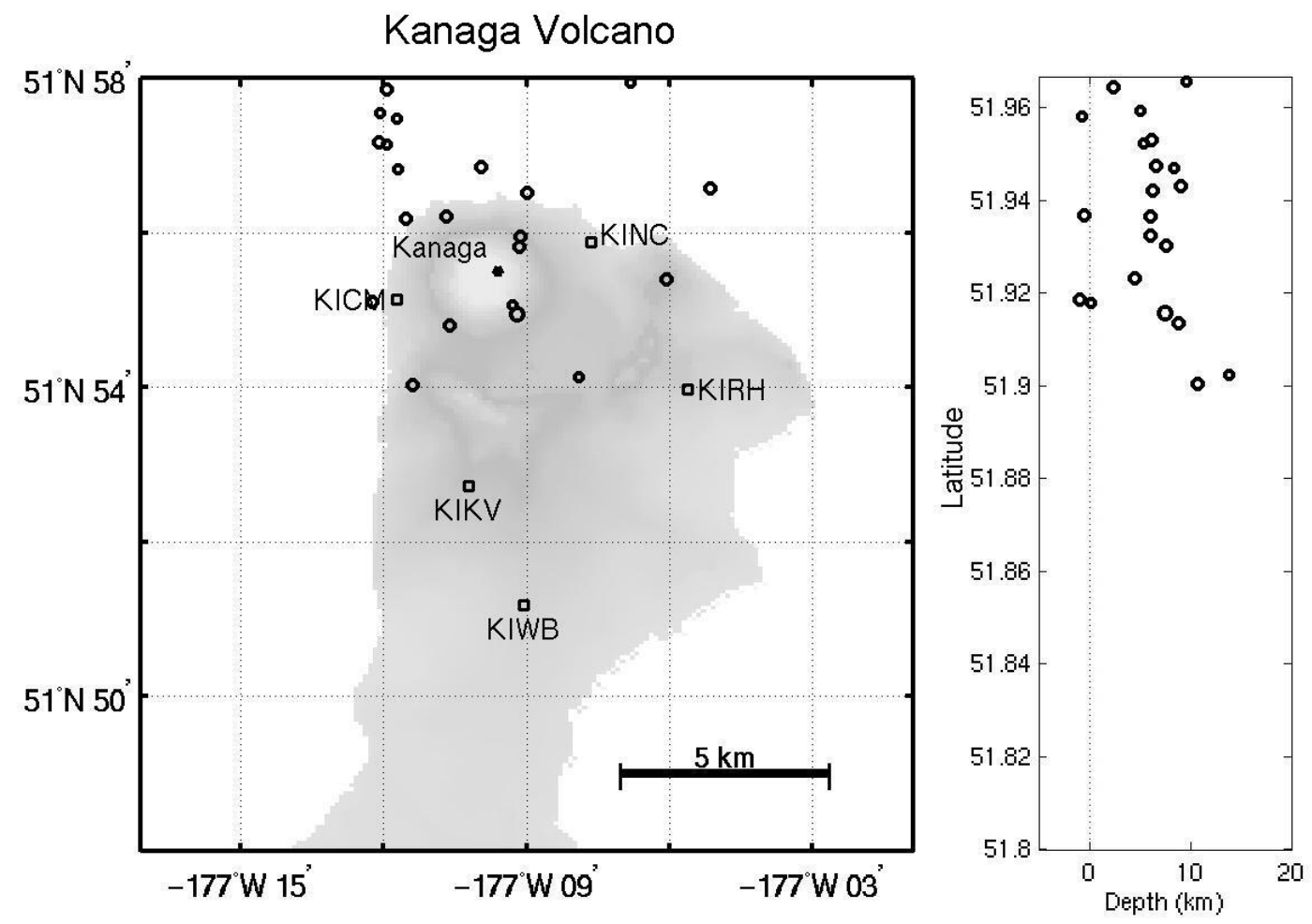

Mag. Symb. Size
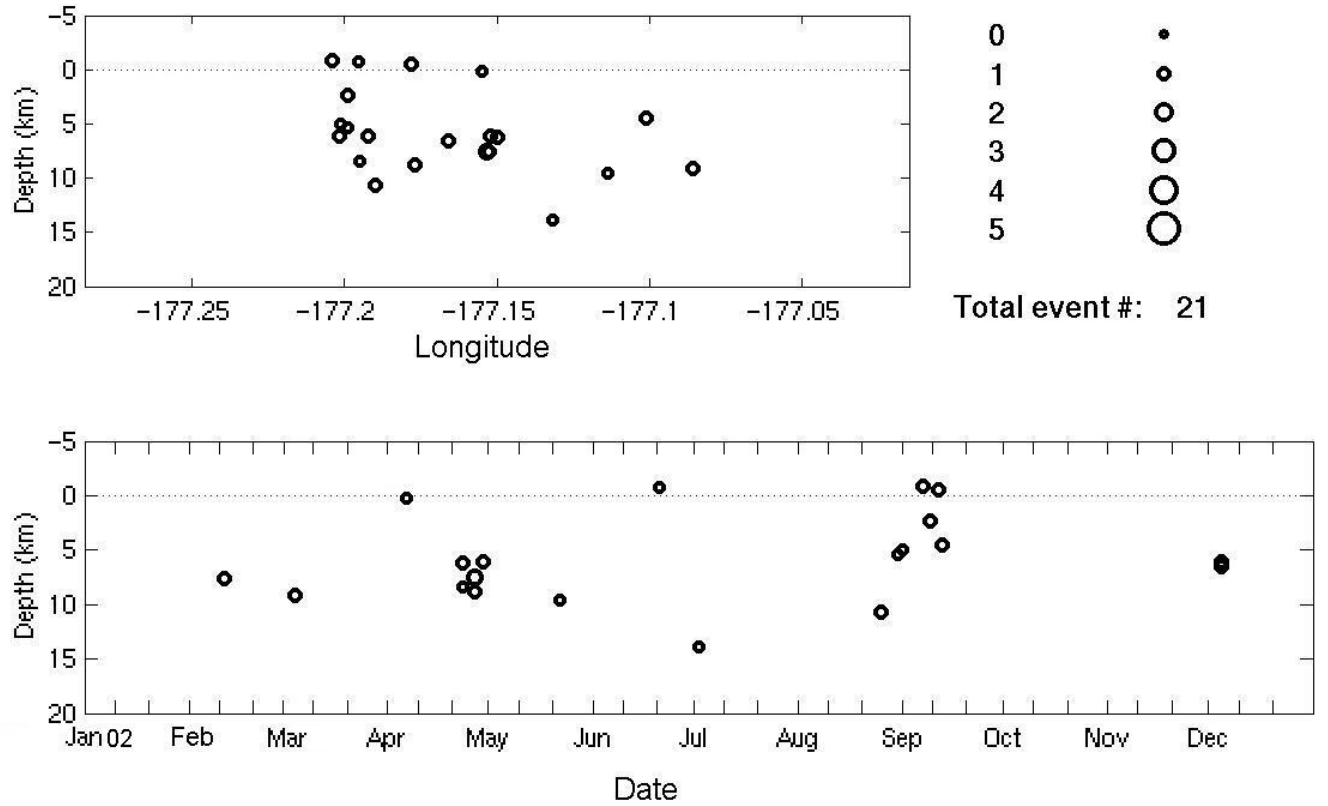

Figure A22. Summary plots of 21 earthquakes located near Kanaga Volcano in 2002. Open circles scaled with magnitude show hypocenter locations shallower than $20 \mathrm{~km}$. Hypocenters with depths of $20 \mathrm{~km}$ and deeper are shown by open triangles scaled with magnitude. Seismic stations are shown by open squares and labeled by station code. (See Appendix B for station information). Closed circles are used to show other points of interest. 


\section{Appendix B: Parameters for all AVO seismic stations.}

Station Latitude (N) Longitude (W) Elevation (m) Seismometer Station open date

\begin{tabular}{llllll}
\multicolumn{7}{l}{ Akutan Peak subnet (7 stations - 11 components) } & & \\
AHB & 5406.916 & 16548.943 & 447 & L-4 & $1996 / 07 / 24$ \\
AKS $^{3}$ & 5406.624 & 16541.803 & 213 & L-22 & $1996 / 07 / 24$ \\
AKT $^{B}$ & 5408.15 & 16546.2 & 12 & CMG-40T & $1996 / 03 / 18$ \\
AKV & 5407.571 & 16557.763 & 863 & L-4 & $1996 / 07 / 24$ \\
HSB & 5411.205 & 16554.743 & 497 & L-4 & $1996 / 07 / 24$ \\
LVA & 5409.655 & 16602.024 & 457 & L-4 & $1996 / 07 / 24$ \\
ZRO & 5405.494 & 16558.678 & 446 & L-4 & $1996 / 07 / 24$
\end{tabular}

Aniakchak Crater subnet (6 stations - 8 components)

$\begin{array}{llllll}\text { AJAX }^{\mathrm{R}} & 5653.370 & 15813.29 & 967 & \text { L-4 } & 2000 / 07 / 10 \\ \text { ANNE } & 5654.763 & 15803.534 & 705 & \text { L-4 } & 1997 / 07 / 18 \\ \text { ANNW } & 5657.986 & 15812.895 & 816 & \text { L-4 } & 1997 / 07 / 18 \\ \text { ANON }^{3} & 5655.188 & 15810.293 & 445 & \text { L-22 } & 2000 / 07 / 10 \\ \text { ANPB } & 5648.141 & 15816.847 & 675 & \text { L-4 } & 1997 / 07 / 18 \\ \text { ANPK } & 5650.499 & 15807.572 & 972 & \text { L-4 } & 1997 / 07 / 18 \\ \text { AZAC } & 5653.727 & 15813.841 & 1057 & \text { L-4 } & 2002 / 07 / 12\end{array}$

Augustine Volcano subnet (9 stations - 14 components)

$\begin{array}{lllllr}\text { AUC } & 5921.596 & 15325.469 & 1175 & \text { L-4 } & 1995 / 09 / 13 \\ \text { AUE } & 5921.531 & 15322.365 & 168 & \text { S-13 } & 1980 / 10 / 29 \\ \text { AUH } & 5921.833 & 15326.591 & 890 & \text { S-13 } & 1978 / 12 / 01 \\ \text { AUI }^{3} & 5920.11 & 15325.66 & 293 & \text { S-13 } & 1978 / 04 / 06 \\ \text { AUL }^{\text {BS }} & 5922.93 & 15326.07 & 360 & \text { S-13,CMG-40T } & 1978 / 08 / 27 \\ \text { AUP } & 5921.74 & 15325.23 & 1033 & \text { S-13 } & 1977 / 09 / 22 \\ \text { AUR } & 5921.766 & 15325.873 & 1183 & \text { L-4 } & 1995 / 11 / 01 \\ \text { AUS } & 5921.599 & 15325.840 & 1226 & \text { L-4 } & 1990 / 09 / 01 \\ \text { AUW } & 5922.205 & 15328.249 & 276 & \text { S-13 } & 1976 / 10 / 17\end{array}$

Mount Dutton subnet (4 stations - 4 components)

$\begin{array}{llllll}\text { BLDY } & 5511.670 & 16247.018 & 259 & \text { L-4 } & 1996 / 07 / 11 \\ \text { DRR3 } & 5458.015 & 16215.671 & 457 & \text { L-4 } & 1996 / 07 / 11 \\ \text { DT1 } & 5506.358 & 16216.709 & 198 & \text { L-4 } & 1991 / 06 / 21 \\ \text { DTN } & 5509.011 & 16214.985 & 366 & \text { S-13 } & 1988 / 07 / 16\end{array}$

Great Sitkin Volcano subnet (6 stations - 8 components)

$\begin{array}{llllll}\text { GSCK } & 5200.712 & 17609.718 & 384 & \text { L-4 } & 1999 / 09 / 15 \\ \text { GSIG } & 5159.181 & 17555.502 & 407 & \text { L-4 } & 1999 / 09 / 03 \\ \text { GSMY } & 5202.594 & 17603.376 & 418 & \text { L-4 } & 1999 / 09 / 03 \\ \text { GSSP } & 5205.566 & 17610.541 & 295 & \text { L-4 } & 1999 / 09 / 15 \\ \text { GSTD }^{3} & 5203.356 & 17608.685 & 873 & \text { L-22 } & 1999 / 09 / 03 \\ \text { GSTR } & 5205.655 & 17603.546 & 536 & \text { L-4 } & 1999 / 09 / 03\end{array}$

\begin{tabular}{llllll}
\multicolumn{6}{l}{ Iliamna Volcano subnet } \\
ILI & 6004.81 & 15257.57 & 823 & L-4 & $1987 / 09 / 15$ \\
ILS & 5957.454 & 15304.083 & 1107 & S-13 & $1996 / 08 / 28$ \\
ILW & 6003.60 & 15308.17 & 1722 & S-13 & $1994 / 09 / 09$ \\
INE & 6003.65 & 15303.75 & 1585 & S-13 & $1990 / 08 / 29$ \\
IVE & 6000.972 & 15300.993 & 1110 & S-13,L-22 & $1996 / 09 / 19$ \\
IVS & 6000.55 & 15304.85 & 2332 & L-4 & $1990 / 08 / 29$
\end{tabular}


AVO Stations-continued.

Station Latitude (N) Longitude (W) Elevation (m) Seismometer $\underline{\text { Station open date }}$

\begin{tabular}{lccccc}
\multicolumn{6}{l}{ Kanaga } \\
KIClcano subnet
\end{tabular}

Katmai volcanic group subnet (18 stations - 24 components)

\begin{tabular}{|c|c|c|c|c|c|}
\hline $\mathrm{ACH}^{3}$ & 5812.64 & 15519.56 & 960 & L-22 & $1996 / 07 / 25$ \\
\hline ANCK & 5811.93 & 15529.64 & 869 & L-4 & $1996 / 07 / 25$ \\
\hline CAHL & 5803.15 & 15518.09 & 807 & L-4 & $1996 / 07 / 25$ \\
\hline CNTC & 5815.87 & 15553.02 & 1158 & L-4 & $1996 / 07 / 25$ \\
\hline KABR & 5807.87 & 15458.15 & 884 & L-4 & 1998/08/12 \\
\hline KAHC & 5838.94 & 15500.36 & 1250 & L-4 & 1998/10/12 \\
\hline KAHG & 5829.64 & 15432.78 & 923 & L-4 & 1998/10/12 \\
\hline KAIC & 5829.10 & 15502.75 & 734 & L-4 & 1998/10/12 \\
\hline $\mathrm{KAPH}^{3}$ & 5835.81 & 15420.81 & 907 & L-22 & 1998/10/12 \\
\hline KARR & 5829.87 & 15442.20 & 610 & L-4 & 1998/10/12 \\
\hline KAWH & 5823.02 & 15447.95 & 777 & L-4 & 1998/10/12 \\
\hline KBM & 5816.50 & 15512.10 & 732 & L-4 & $1991 / 07 / 22$ \\
\hline KCE & 5814.60 & 15511.00 & 777 & L-4 & $1991 / 07 / 22$ \\
\hline $\mathrm{KCG}^{3}$ & 5818.457 & 15506.684 & 762 & L-22 & 1988//08/01 \\
\hline KEL & 5826.401 & 15544.442 & 975 & L-4 & 1988//08/01 \\
\hline KJL & 5803.24 & 15534.39 & 792 & L-4 & $1996 / 07 / 25$ \\
\hline KVT & 5822.90 & 15517.70 & 457 & L-4 & 1988//08/01 \\
\hline MGLS & 5808.06 & 15509.65 & 472 & L-4 & $1996 / 07 / 25$ \\
\hline \multicolumn{6}{|c|}{ Makushin Volcano subnet (6 stations - 8 components) } \\
\hline MCIR & 5357.08 & 16653.51 & 800 & L-4 & $1996 / 07 / 25$ \\
\hline MGOD & 5347.68 & 16652.35 & 695 & L-4 & $1996 / 07 / 25$ \\
\hline MNAT & 5353.03 & 16641.00 & 390 & L-4 & $1996 / 07 / 25$ \\
\hline MSOM & 5348.99 & 16656.94 & 50 & L-4 & $1996 / 07 / 25$ \\
\hline MSW $^{3}$ & 5354.88 & 16646.96 & 418 & $\mathrm{~L}-22$ & $1996 / 07 / 25$ \\
\hline MTBL & 5358.16 & 16640.71 & 865 & L-4 & $1996 / 07 / 25$ \\
\hline \multicolumn{6}{|c|}{ Okmok Volcano subnet (8 stations - 8 components) } \\
\hline OKAS & 5324.319 & 16821.686 & 270 & L-4 & 2003/01/09 \\
\hline OKCF & 5323.689 & 16808.299 & 685 & L-4 & 2003/01/09 \\
\hline OKID & 5328.587 & 16749.088 & 437 & L-4 & 2003/01/09 \\
\hline OKRE & 5331.163 & 16809.964 & 420 & L-4 & 2003/01/09 \\
\hline OKSP & 5315.099 & 16817.548 & 608 & L-4 & 2003/01/09 \\
\hline OKTU & 5322.967 & 16802.571 & 646 & L-4 & 2003/01/09 \\
\hline OKWE & 5328.270 & 16814.512 & 445 & L-4 & 2003/01/09 \\
\hline OKWR & 5326.031 & 16812.455 & 1017 & L-4 & 2003/01/09 \\
\hline
\end{tabular}


AVO Stations-continued.

$\underline{\text { Station }}$ Latitude (N) Longitude (W) Elevation (m) Seismometer $\underline{\text { Station open date }}$

$\begin{array}{lccccc}\text { Pavlof Volcano subnet (8 stations - 10 components) } & & \\ \text { BLHA } & 5542.227 & 16203.907 & 411 & \text { L-4 } & 1996 / 07 / 11 \\ \text { DOL } & 5508.960 & 16151.683 & 442 & \text { L-4 } & 1996 / 07 / 11 \\ \text { HAG } & 5519.068 & 16154.150 & 503 & \text { L-4 } & 1996 / 07 / 11 \\ \text { PN7A } & 5526.009 & 16159.757 & 838 & \text { L-4 } & 1996 / 07 / 11 \\ \text { PS1A } & 5525.321 & 16144.425 & 293 & \text { L-4 } & 1996 / 07 / 11 \\ \text { PS4A } & 5520.811 & 16151.233 & 322 & \text { L-4 } & 1996 / 07 / 11 \\ \text { PV6 } & 5527.227 & 16155.138 & 747 & \text { L-22 } & 1996 / 07 / 11 \\ \text { PVV } & 5522.438 & 16147.396 & 161 & \text { L-4 } & 1996 / 07 / 11\end{array}$

Redoubt Volcano subnet (7 stations - 12 components)

$\begin{array}{llllll}\text { DFR } & 6035.514 & 15241.160 & 1090 & \text { L-4 } & 1988 / 08 / 15 \\ \text { NCT } & 6033.789 & 15255.568 & 1079 & \text { L-4 } & 1988 / 08 / 14 \\ \text { RDN } & 6031.370 & 15244.256 & 1400 & \text { L-4 } & 1988 / 08 / 13 \\ \text { RDT } & 6034.394 & 15224.315 & 930 & \text { L-4 } & 1971 / 08 / 09 \\ \text { RED }^{3} & 6025.192 & 15246.308 & 1064 & \text { L-4 } & 1990 / 08 / 30 \\ \text { REF }^{3 *} & 6029.35 & 15242.10 & 1801 & \text { L-22 } & 1992 / 07 / 27 \\ \text { RSO } & 6027.73 & 15245.23 & 1921 & \text { L-4 } & 1990 / 03 / 01\end{array}$

Shishaldin Volcano subnet (6 stations - 8 components)

$\begin{array}{llllll}\text { BRPK } & 5438.719 & 16344.475 & 420 & \text { L-4 } & 1997 / 07 / 27 \\ \text { ISNN } & 5449.925 & 16346.700 & 546 & \text { L-4 } & 1997 / 07 / 27 \\ \text { ISTK } & 5443.980 & 16342.330 & 453 & \text { L-4 } & 1997 / 07 / 27 \\ \text { SSLN } & 5448.709 & 16359.756 & 637 & \text { L-4 } & 1997 / 07 / 27 \\ \text { SSLS } & 5442.718 & 16359.926 & 771 & \text { L-22 } & 1997 / 07 / 27 \\ \text { SSLW } & 5446.307 & 16407.282 & 628 & \text { L-4 } & 1997 / 07 / 27\end{array}$

Mount Spurr subnet (10 stations - 12 components)

$\begin{array}{llllll}\text { BGL } & 6116.02 & 15223.30 & 1207 & \text { L-4 } & 1989 / 08 / 13 \\ \text { BKG } & 6104.21 & 15215.76 & 1009 & \text { L-4 } & 1991 / 07 / 01 \\ \text { CGL } & 6118.46 & 15200.40 & 1082 & \text { L-4 } & 1981 / 09 / 22 \\ \text { CKL } & 6111.79 & 15220.27 & 1265 & \text { L-4 } & 1989 / 08 / 05 \\ \text { CKN } & 6113.44 & 15210.89 & 735 & \text { L-4 } & 1991 / 08 / 19 \\ \text { CKT } & 6112.05 & 15212.37 & 975 & \text { L-4 } & 1992 / 09 / 16 \\ \text { CP2 } & 6115.85 & 15214.51 & 1981 & \text { L-4 } & 1992 / 10 / 23 \\ \text { CRP }^{3} & 6116.02 & 15209.33 & 1622 & \text { L-4 } & 1981 / 08 / 26 \\ \text { NCG } & 6124.22 & 15209.40 & 1244 & \text { L-4 } & 1989 / 08 / 06 \\ \text { SPU } & 6110.90 & 15203.26 & 800 & \text { L-4 } & 1971 / 08 / 10 \\ & & & & & \\ \text { Mount Veniaminof subnet (9 stations - 9 components) } & & \text { L-4 } & 2002 / 10 / 03 \\ \text { BPBC } & 5635.383 & 15827.153 & 584 & \text { L-4 } & 2002 / 02 / 06 \\ \text { VNFG } & 5617.140 & 15833.066 & 1068 & \text { L-4 } & 2002 / 02 / 06 \\ \text { VNHG } & 5613.267 & 15809.853 & 963 & \text { L-4 } & 2002 / 02 / 06 \\ \text { VNKR } & 5601.871 & 15922.068 & 620 & \text { L-4 } & 2002 / 06 / 20 \\ \text { VNNF } & 5617.022 & 15918.961 & 1153 & \text { L-4 } & 2002 / 02 / 06 \\ \text { VNSG } & 5607.549 & 15905.121 & 761 & \text { L-4 } & 2002 / 02 / 06 \\ \text { VNSS } & 5613.600 & 15927.290 & 1728 & \text { L-4 } & 2002 / 06 / 20 \\ \text { VNSW } & 5604.317 & 15933.508 & 716 & \text { L-4 } & 2002 / 02 / 06\end{array}$


AVO Stations-continued.

$\underline{\text { Station }}$ Latitude (N) Longitude (W) Elevation (m) Seismometer $\underline{\text { Station open date }}$

\begin{tabular}{lcccll}
\multicolumn{6}{l}{ Westdahl Peak subnet (6 stations - 8 components) } \\
WESE & 5428.344 & 16435.188 & 953 & L-4 & $1998 / 08 / 28$ \\
WESN & 5434.342 & 16434.804 & 549 & L-4 & $1998 / 10 / 17$ \\
WESS $^{3}$ & 5428.795 & 16443.428 & 908 & L-22 & $1998 / 08 / 28$ \\
WFAR & 5431.967 & 16446.690 & 640 & L-4 & $1998 / 08 / 28$ \\
WPOG & 5435.776 & 16444.772 & 445 & L-4 & $1998 / 10 / 17$ \\
WTUG & 5450.792 & 16423.258 & 636 & L-4 & $1998 / 10 / 17$
\end{tabular}

\begin{tabular}{|c|c|c|c|c|c|}
\hline \multicolumn{6}{|c|}{ Mount Wrangell subnet (4 stations - 6 components) } \\
\hline WACK $^{3}$ & 6159.178 & 14419.704 & 2280 & $\mathrm{~L}-22$ & $2000 / 07 / 31$ \\
\hline WANC & 6200.192 & $144 \quad 4.194$ & 4190 & L-4 & 2000/07/31 \\
\hline WASW & 6155.692 & 14410.346 & 2164 & L-4 & 2001/08/03 \\
\hline WAZA & 6104.506 & 1449.132 & 2564 & L-4 & $2001 / 08 / 03$ \\
\hline \multicolumn{6}{|c|}{ Regional stations (14 stations - 14 components) } \\
\hline ADAG & 5158.812 & 17636.104 & 286 & $\mathrm{~L}-4$ & $1999 / 09 / 15$ \\
\hline BGM & 5923.56 & 15513.76 & 625 & L-4 & 1978/09/08 \\
\hline BGR & 6045.45 & 15225.06 & 985 & $\mathrm{~L}-4$ & 1991/07/01 \\
\hline CDD & 5855.79 & 15338.58 & 622 & S-13 & 1981/08/17 \\
\hline CNP & 5931.55 & 15114.16 & 564 & L-4 & 1983/07/01 \\
\hline ETKA & 5151.712 & 17624.351 & 290 & L-4 & 1999/09/15 \\
\hline HOM & 5939.50 & 15138.60 & 198 & $\mathrm{~L}-4$ & 1976/08/00 \\
\hline MMN & 5911.11 & 15420.20 & 442 & S-13 & $1981 / 08 / 22$ \\
\hline NNL & 602.66 & 15117.36 & 381 & L-4 & $1972 / 08 / 24$ \\
\hline OPT & 5939.16 & 15313.78 & 450 & S-13 & $1974 / 00 / 00$ \\
\hline PDB & 5947.27 & 15411.55 & 305 & S-13 & 1978/09/09 \\
\hline STLK & 6129.923 & 15149.979 & 945 & L-4 & 1997/09/01 \\
\hline SYI & 5836.60 & 15223.45 & 149 & S-13 & $1990 / 08 / 27$ \\
\hline XLV & 5927.28 & 15140.30 & 320 & S-13 & $1987 / 09 / 16$ \\
\hline
\end{tabular}

Station Codes:

${ }^{3}$ Three-component short-period station

${ }^{\mathrm{B}}$ Three-component broadband station

${ }^{\mathrm{R}}$ Station removed during in 2002

${ }^{\mathrm{S}}$ Station also includes a single short-period vertical station

${ }^{*} \mathrm{REF}$ also has a low-gain vertical component.

Seismometer Codes:

CMG-40T: Guralp CMG-40T 60 second natural period broadband seismometer

L-4: $\quad$ Mark Products L4 one second natural period seismometer

L-22: $\quad$ Mark Products L22 0.5 second natural period seismometer

S-13: $\quad$ Teledyne Geotech S-13 one second natural period seismometer 
Appendix C: Figures showing the location of the permanent AVO regional and volcano-specific seismic stations. In all figures, closed circles show points of interest and open squares show seismic stations.

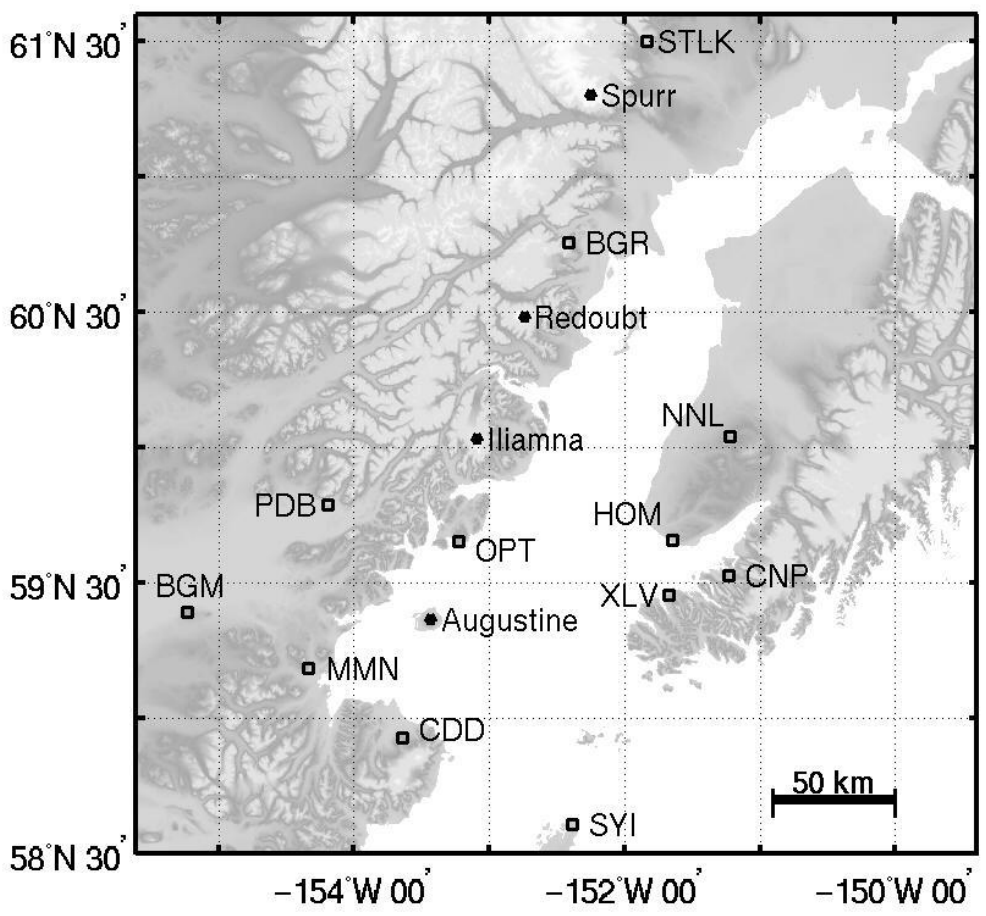

Figure C1. AVO seismic stations in Cook Inlet not associated with any specific volcano.

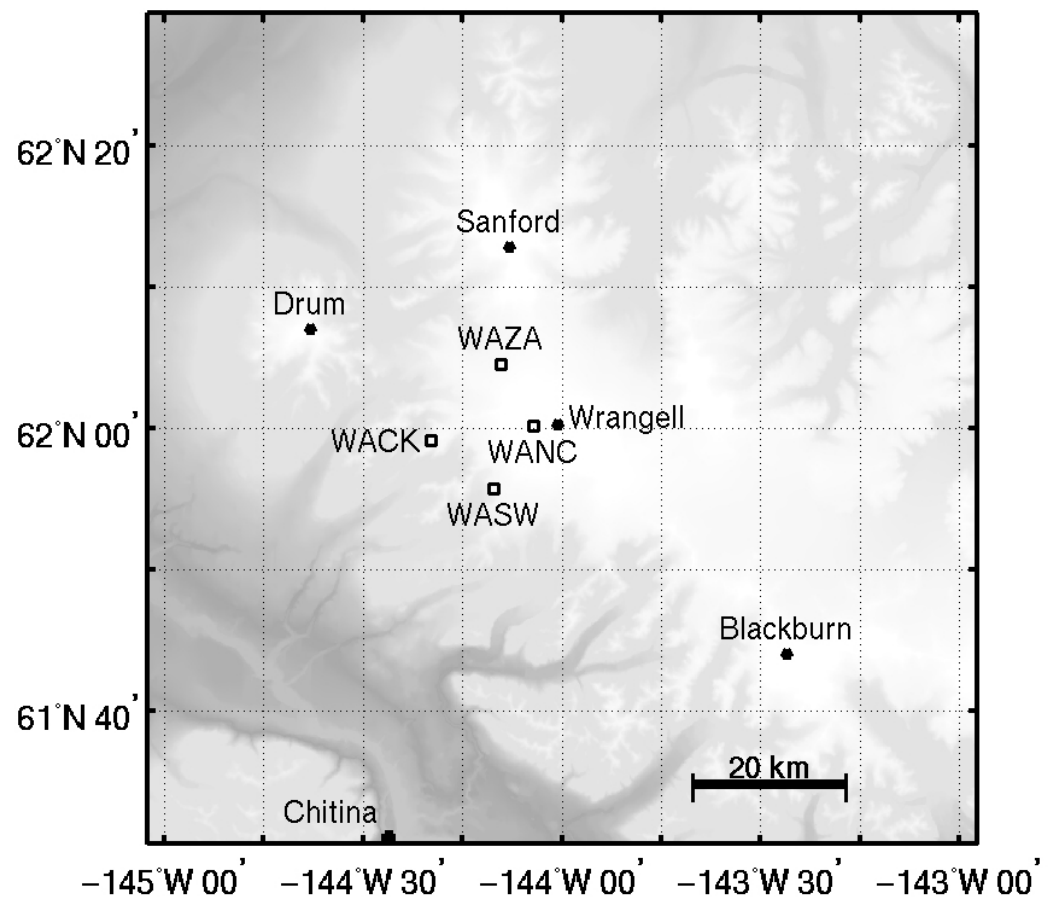

Figure C2. AVO seismic stations near Mount Wrangell. 


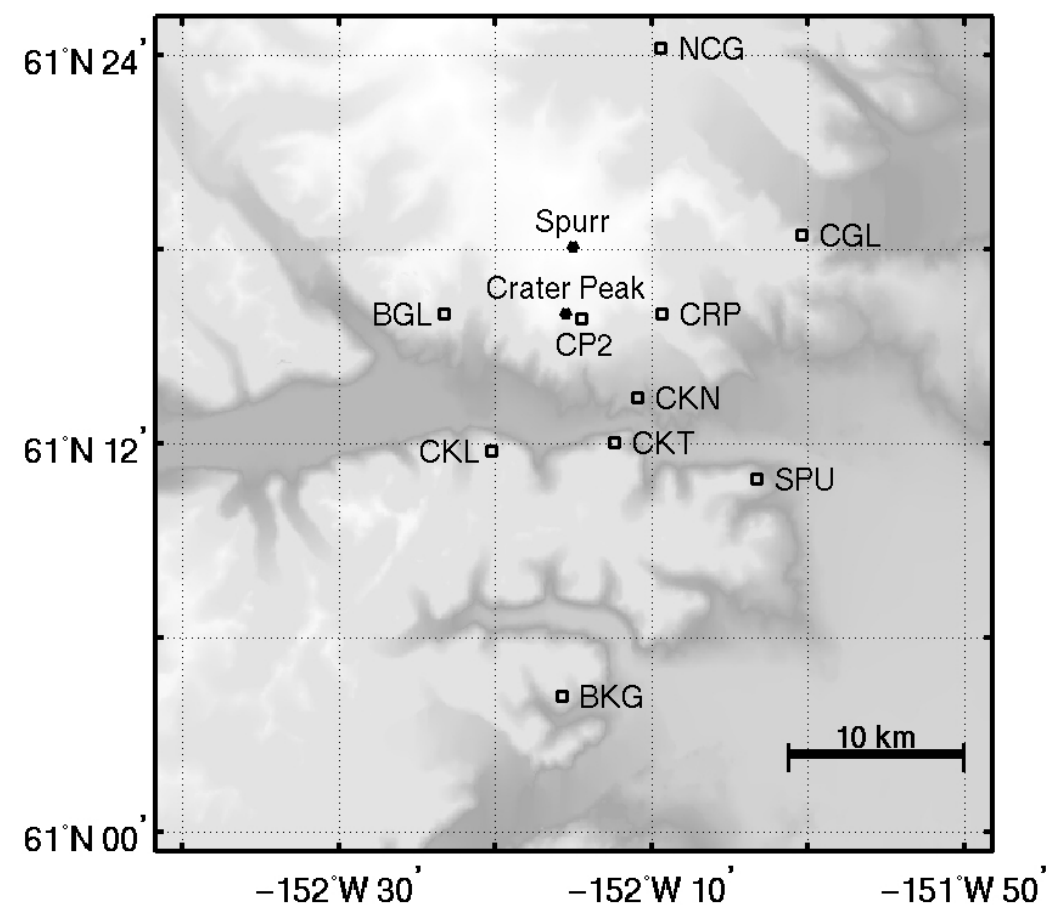

Figure C3. AVO seismic stations near Mount Spurr.

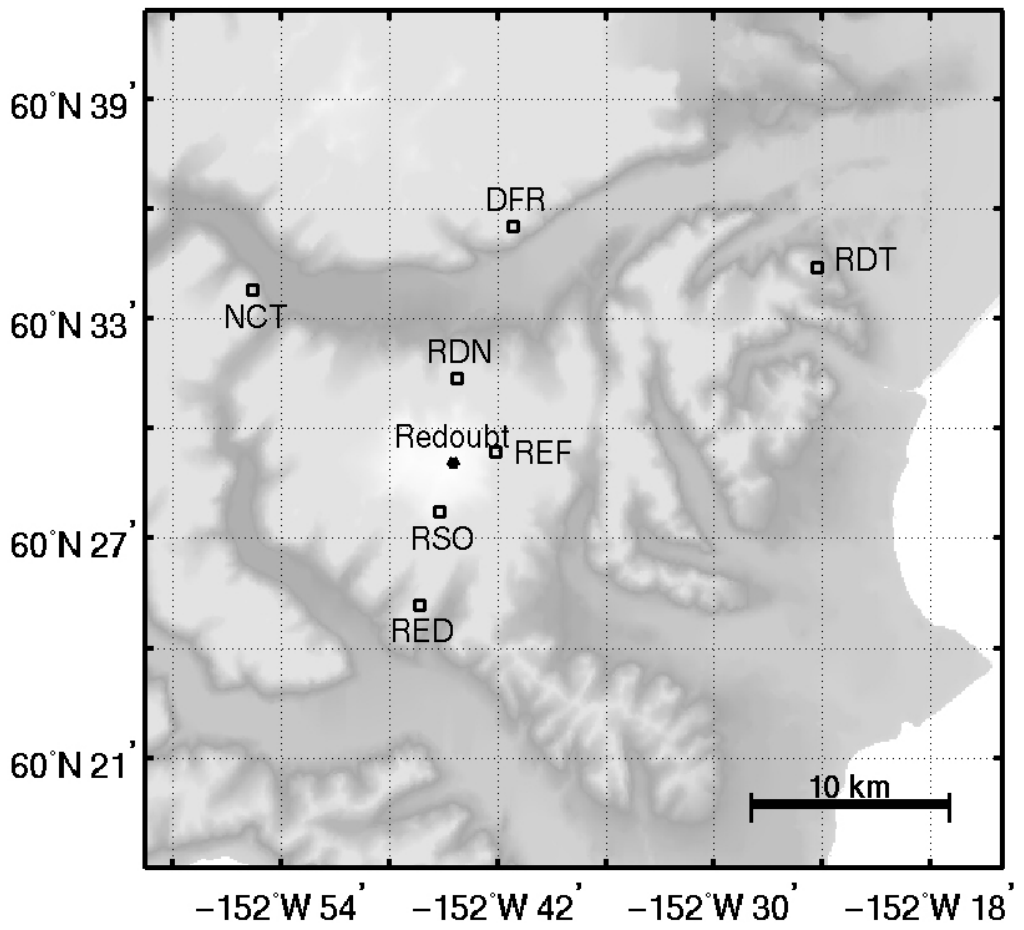

Figure C4. AVO seismic stations near Redoubt Volcano. 


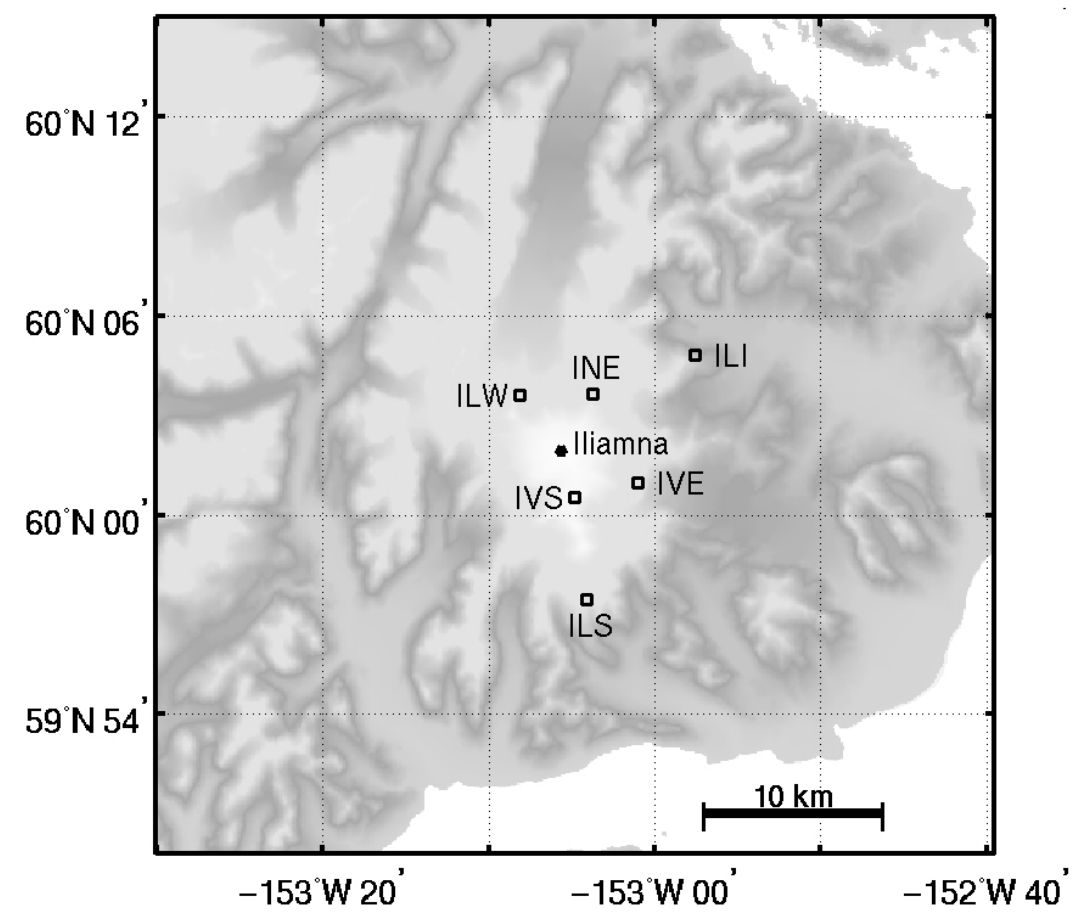

Figure C5. AVO seismic stations near Iliamna Volcano.

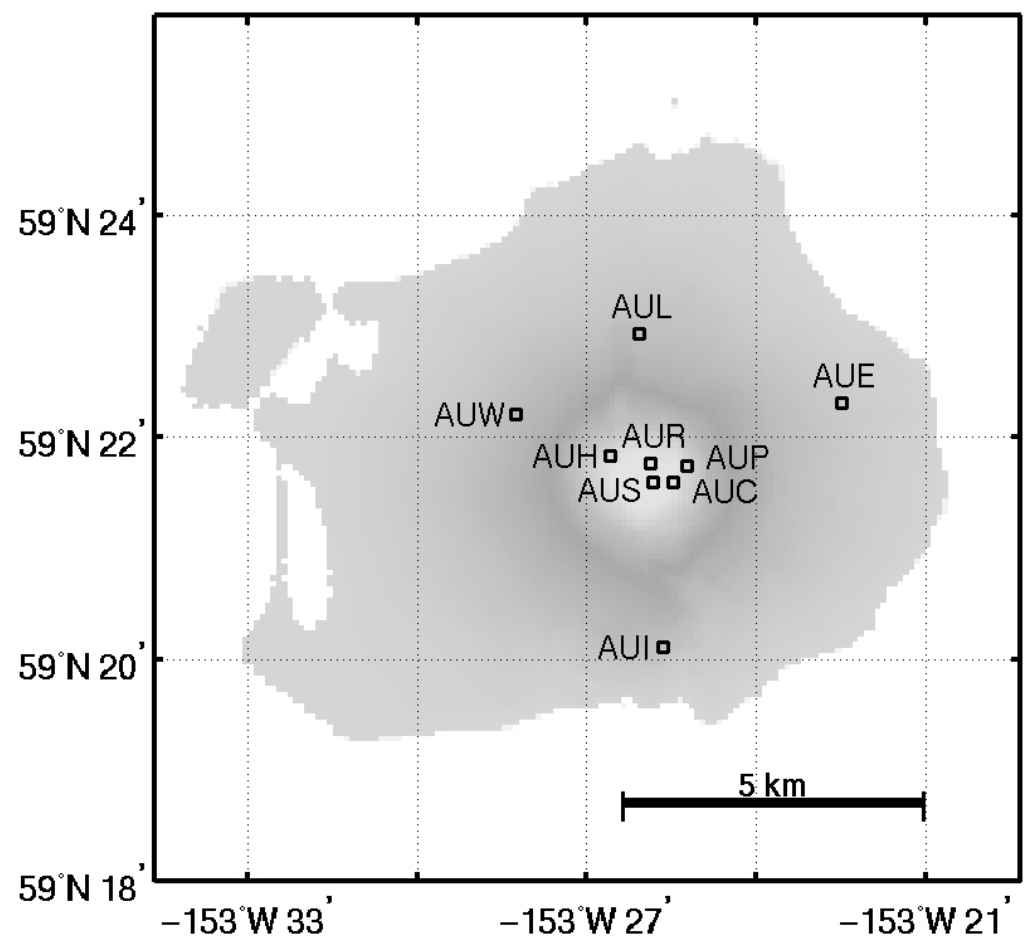

Figure C6. AVO seismic stations near Augustine Volcano. 


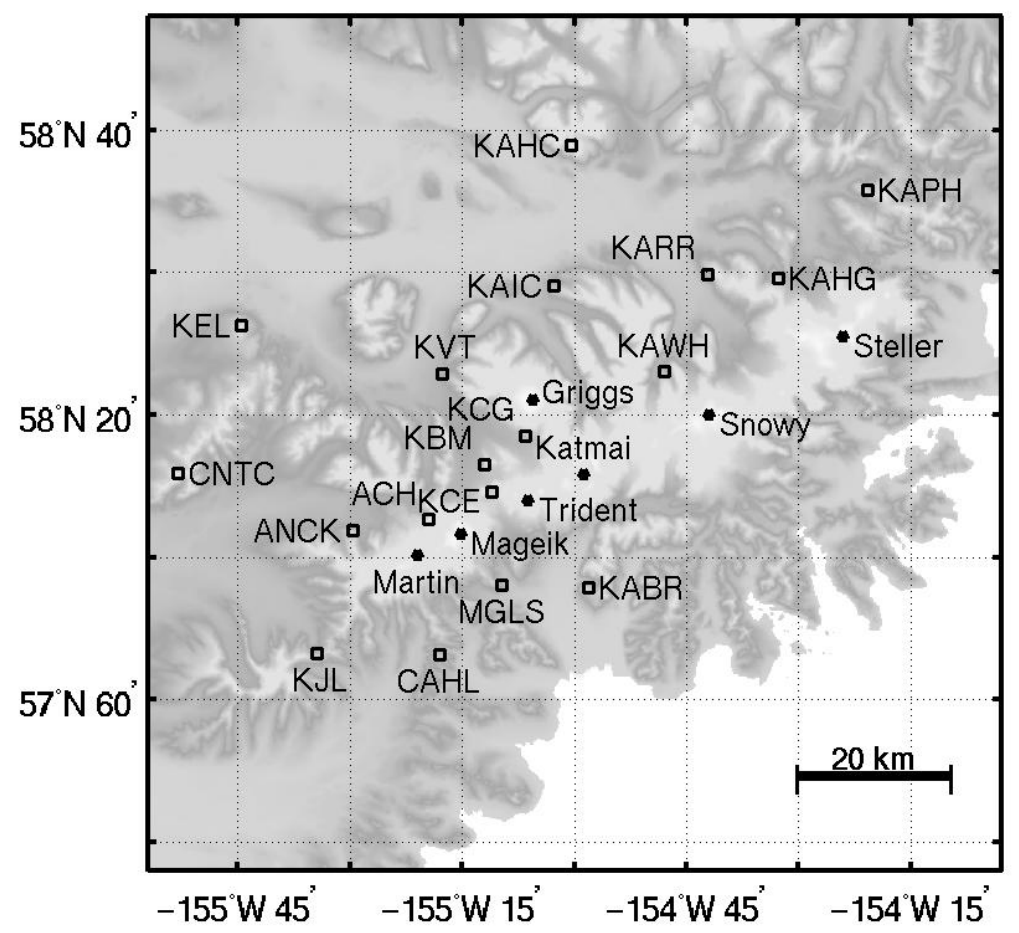

Figure C7. AVO seismic stations near the Katmai volcanic group.

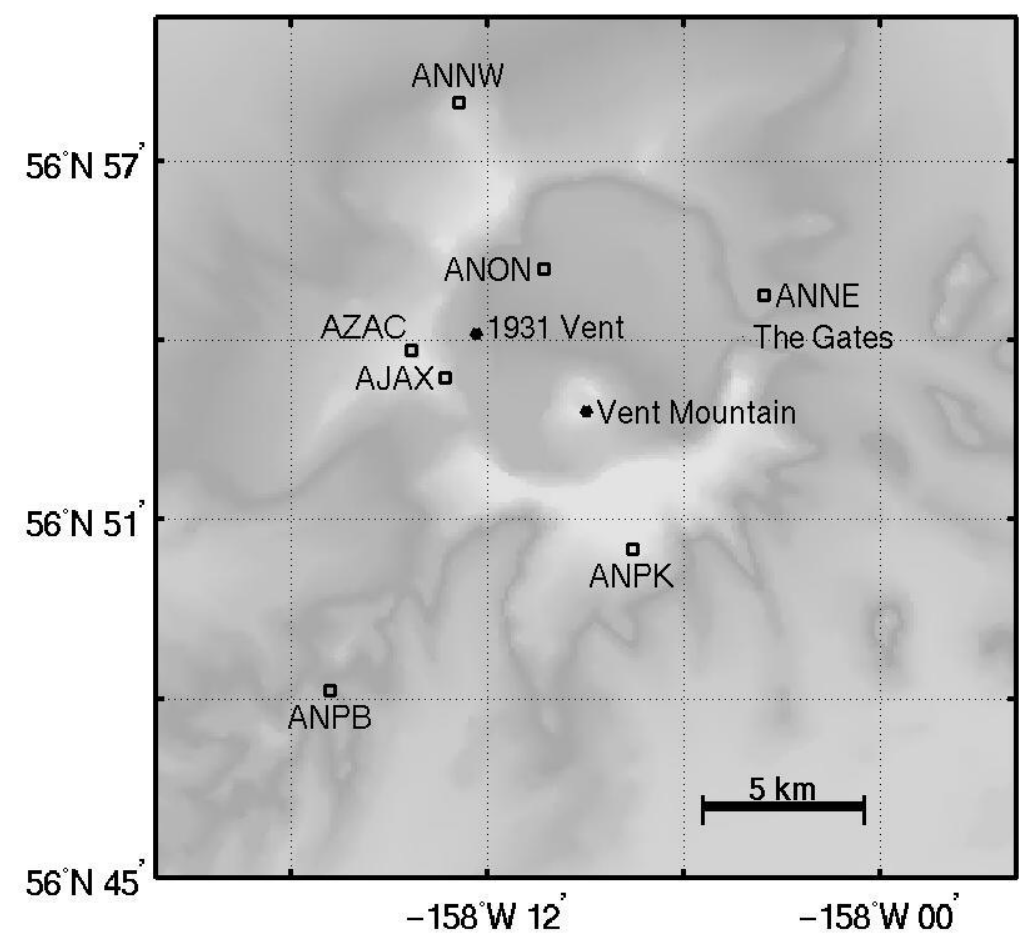

Figure C8. AVO seismic stations near Aniakchak Crater. 


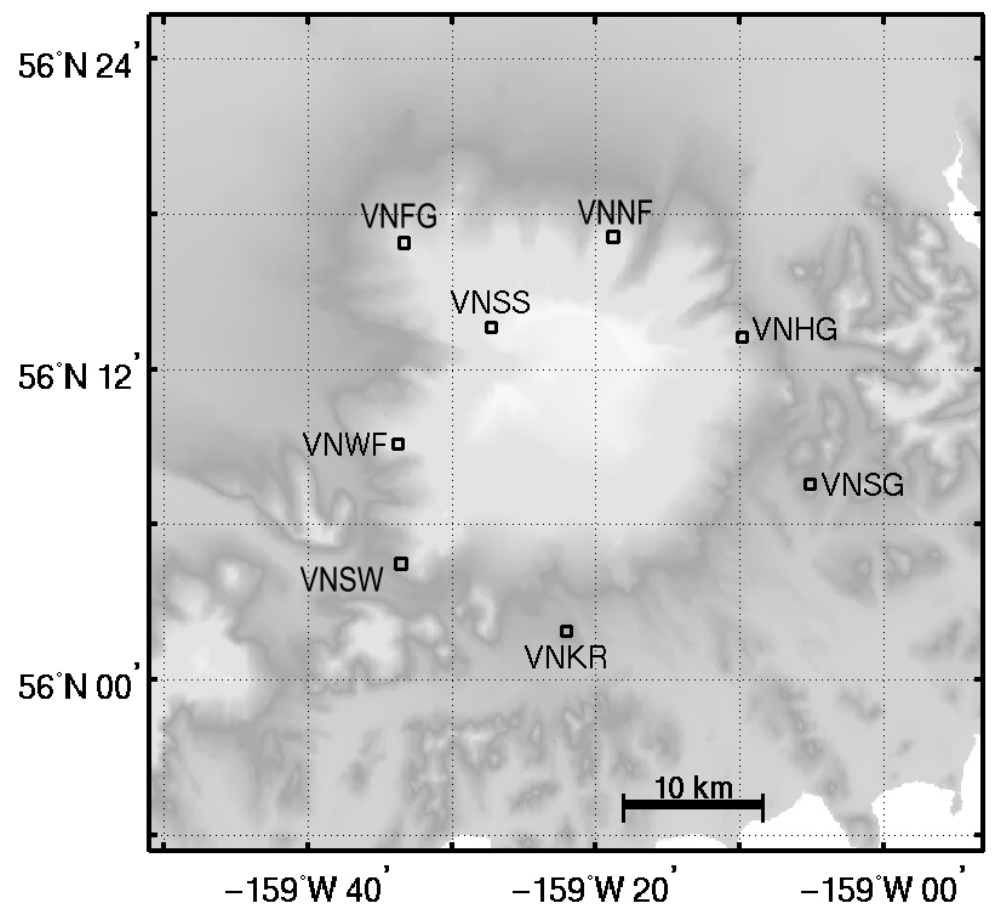

Figure C9. AVO seismic stations near Mount Veniaminof. Seismic station BPBC is not shown and is located $70 \mathrm{~km}$ northeast of Mount Veniaminof.

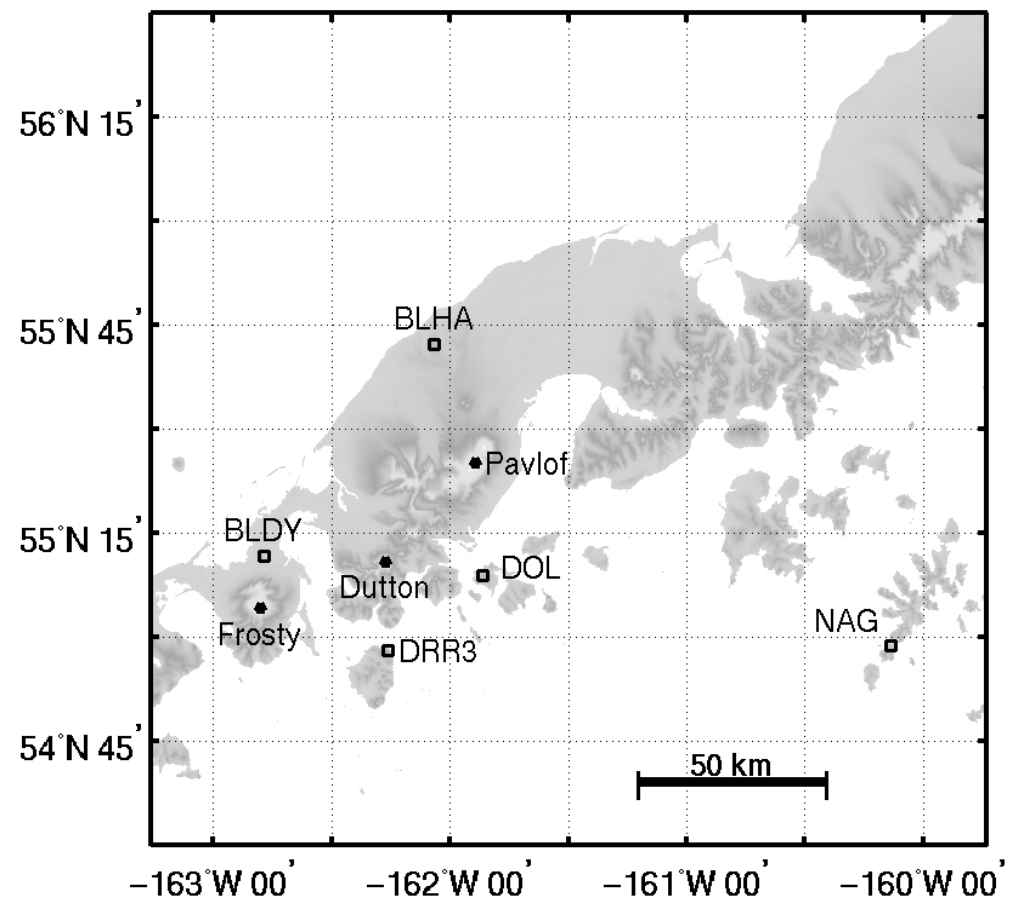

Figure C10. Regional AVO seismic stations on the western end of the Alaska Peninsula. Seismic station NAG is maintained by the Alaska Earthquake Information Center. 


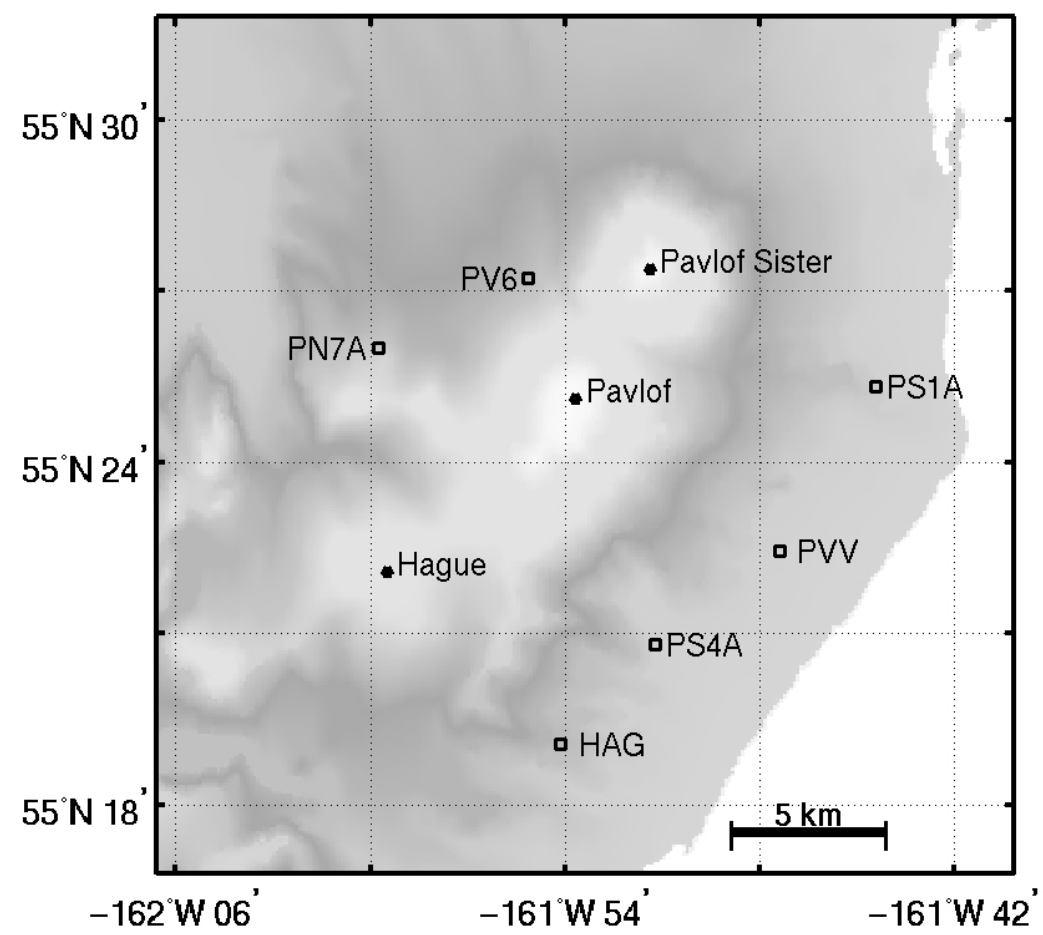

Figure C11. AVO seismic stations near Pavlof Volcano.

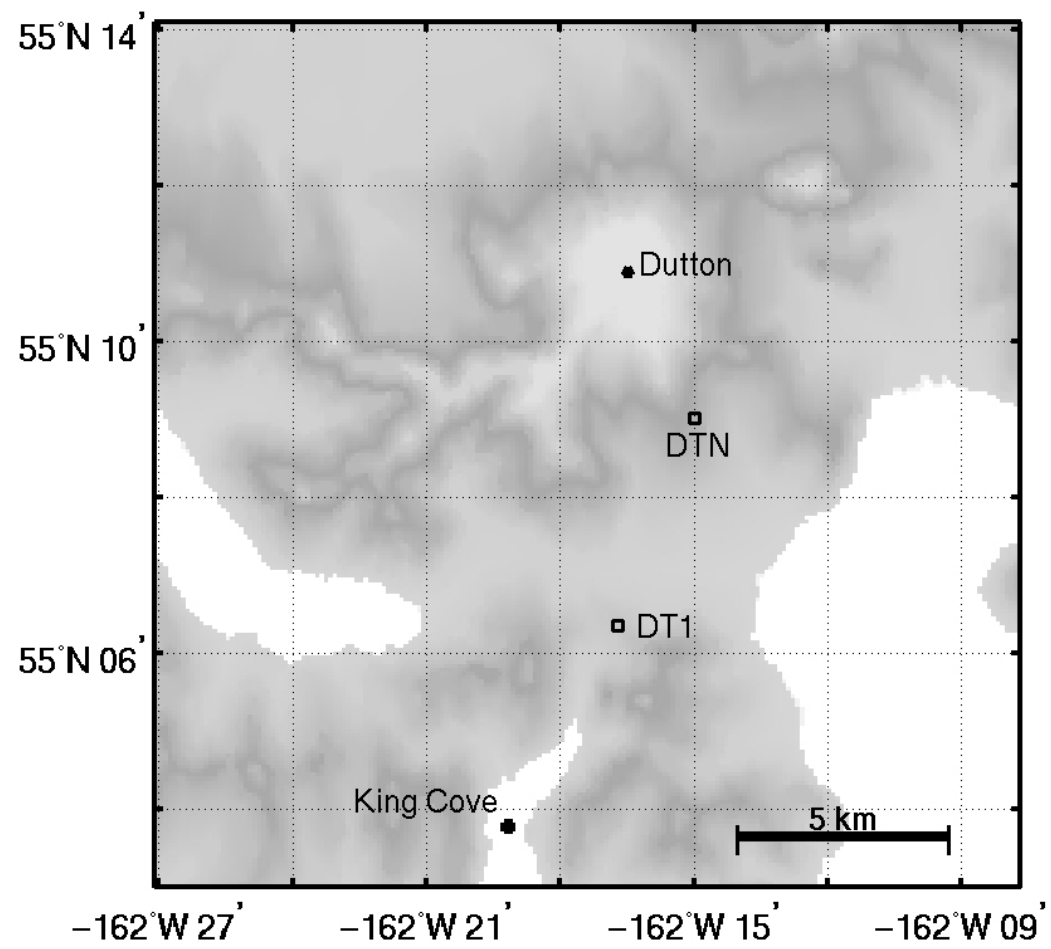

Figure C12. AVO seismic stations near Mount Dutton. 


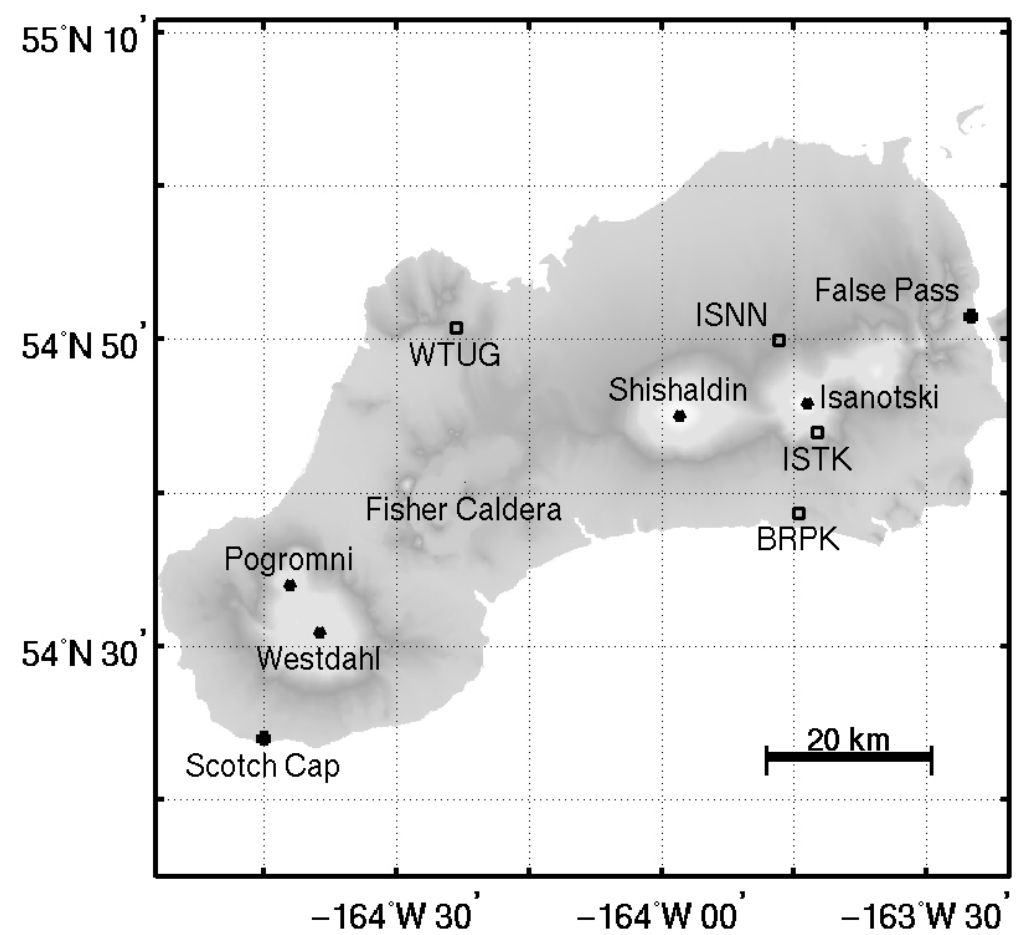

Figure C13. Regional AVO seismic stations on Unimak Island.

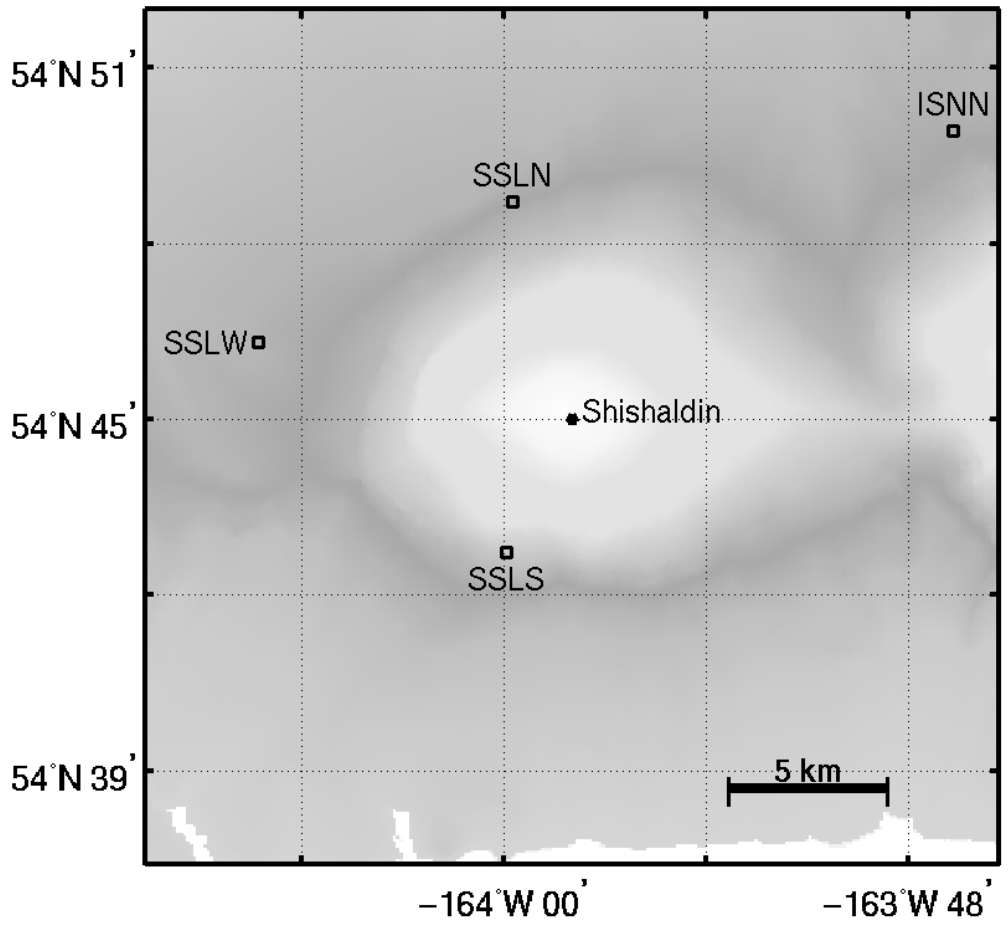

Figure C14. AVO seismic stations near Shishaldin Volcano. 


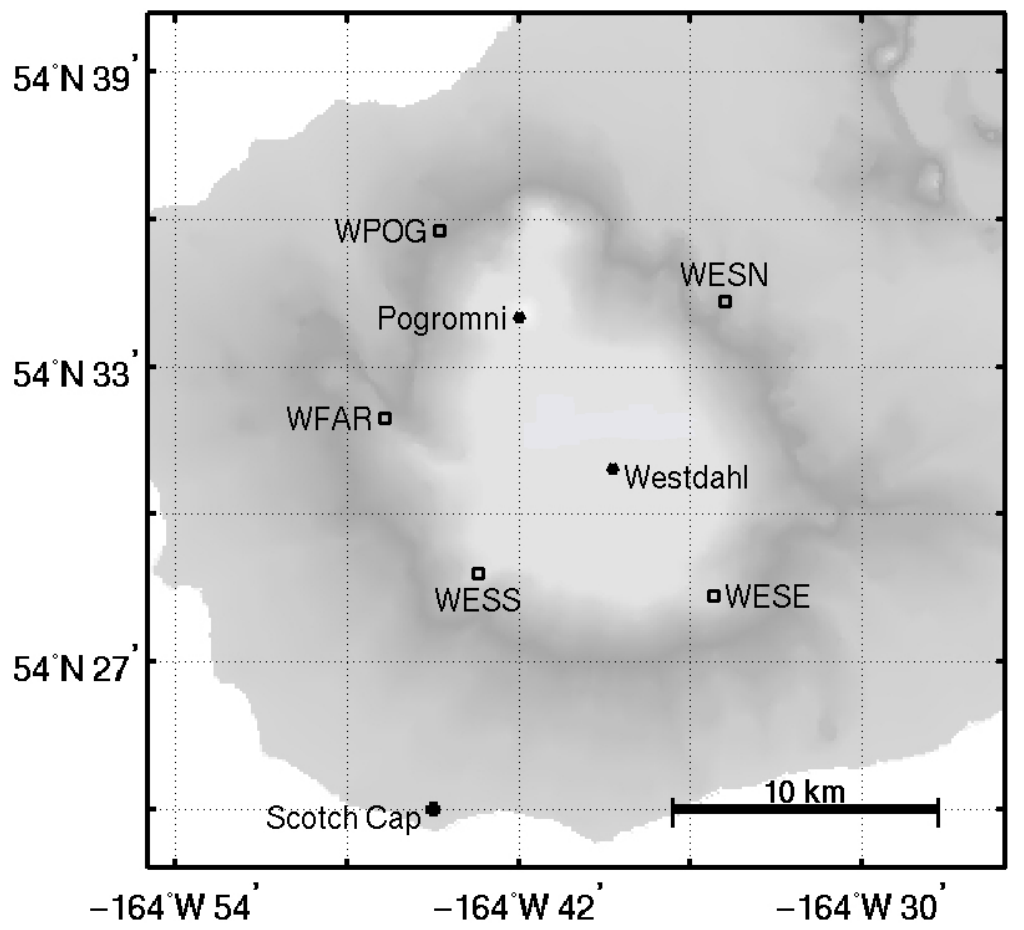

Figure C15. AVO seismic stations near Westdahl Peak.

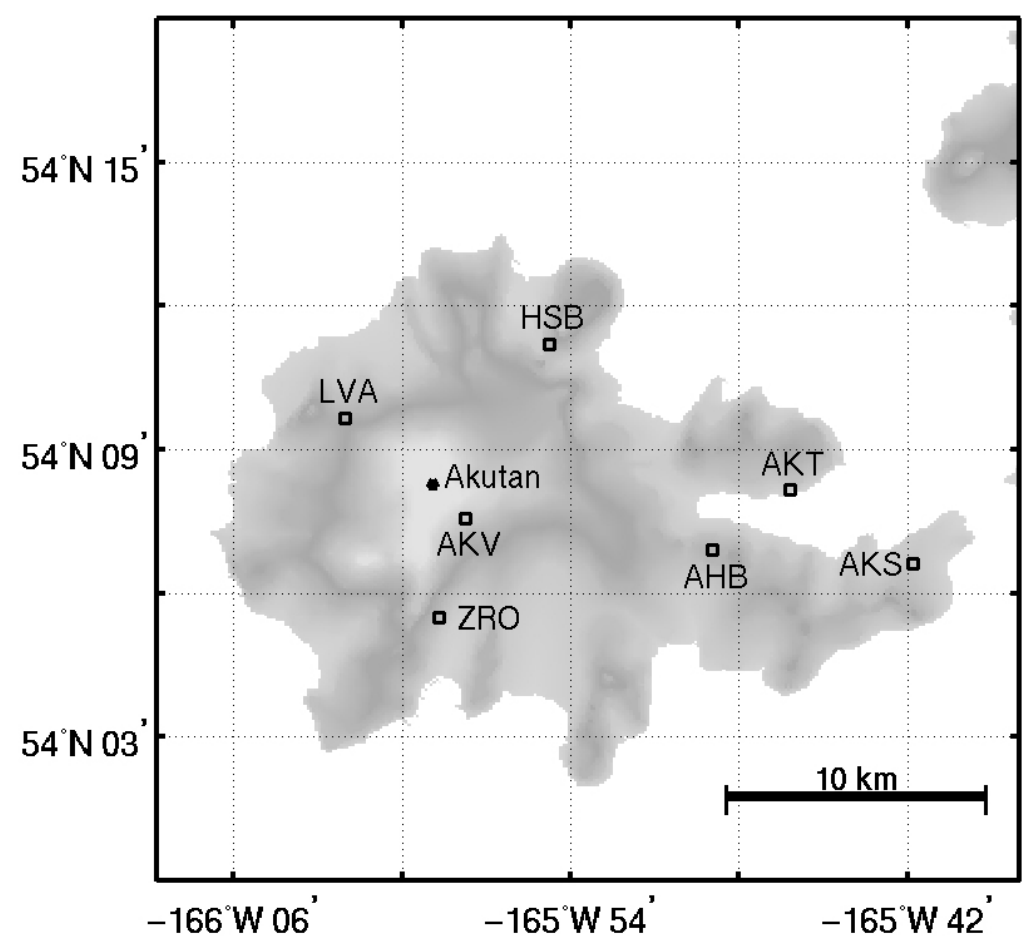

Figure C16. AVO seismic stations near Akutan Peak. 


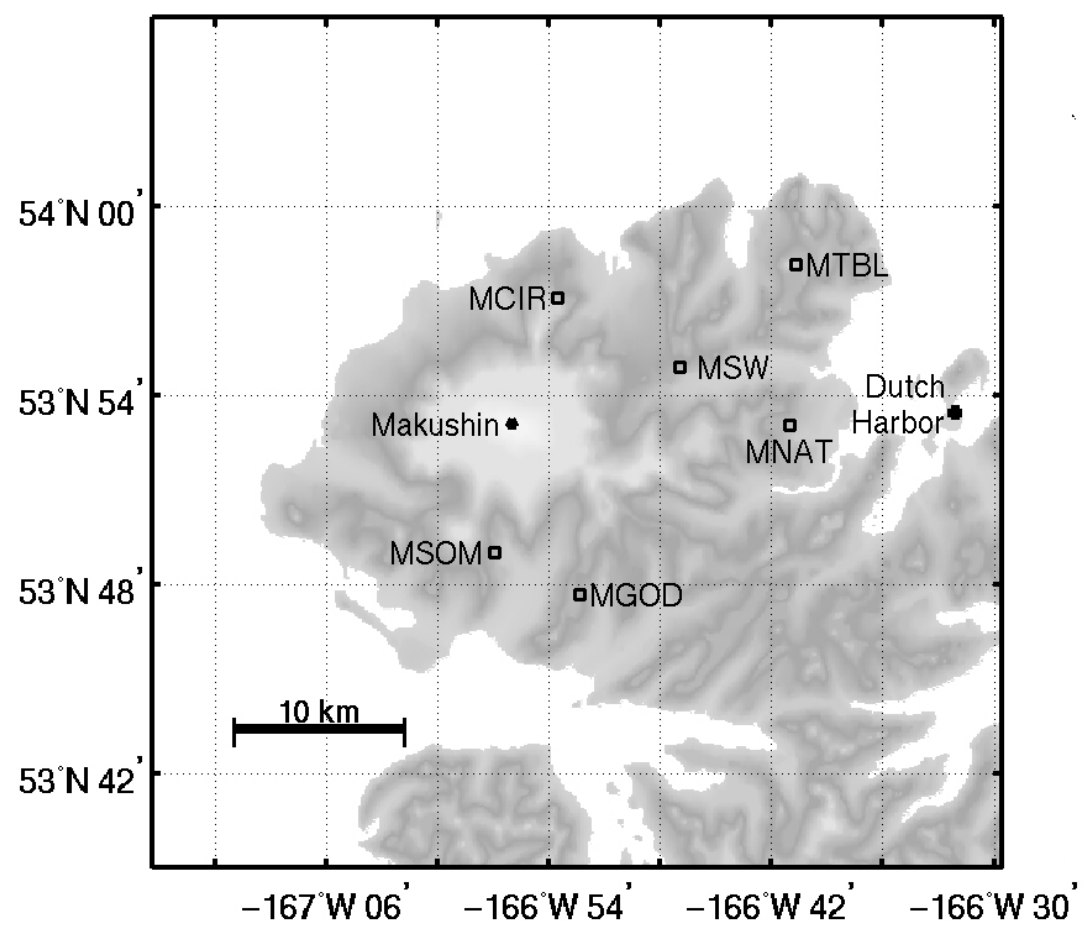

Figure C17. AVO seismic stations near Makushin Volcano.

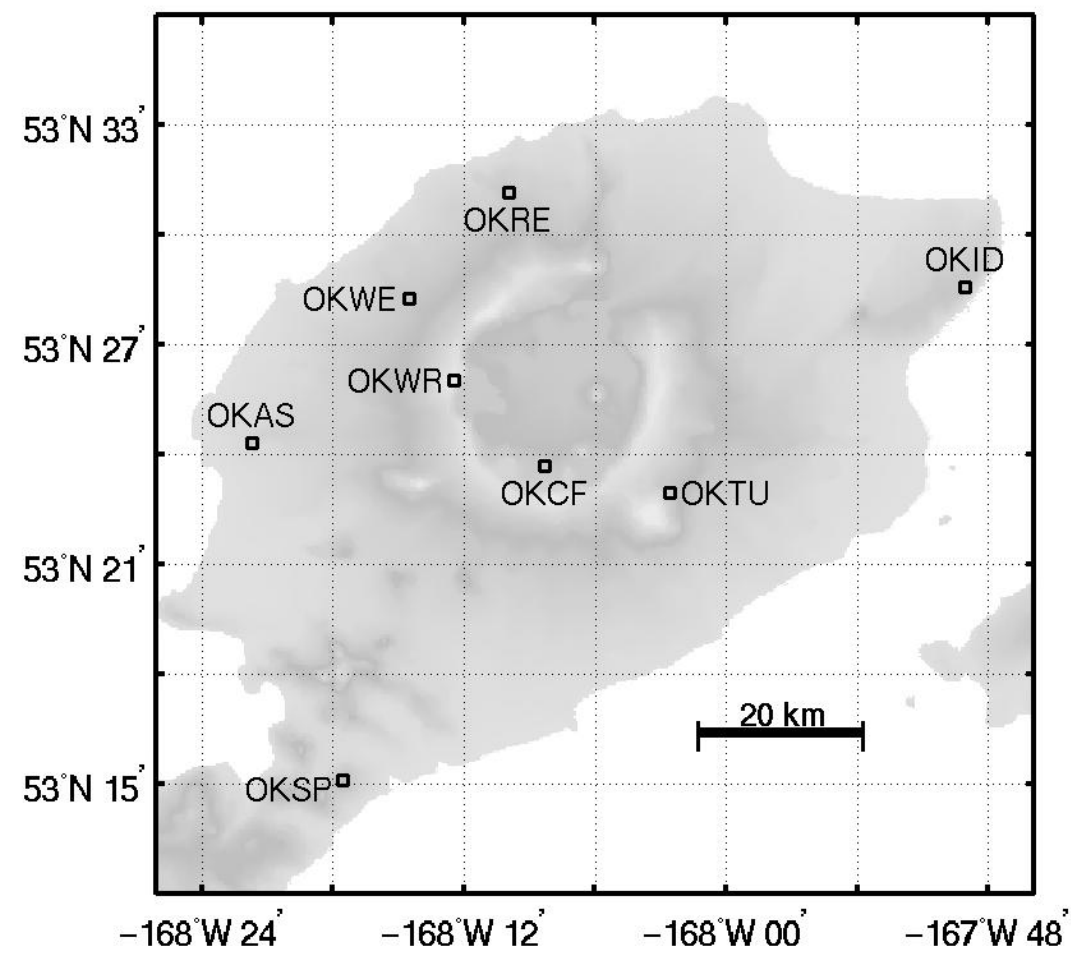

Figure C18. AVO seismic stations near Okmok Volcano. 


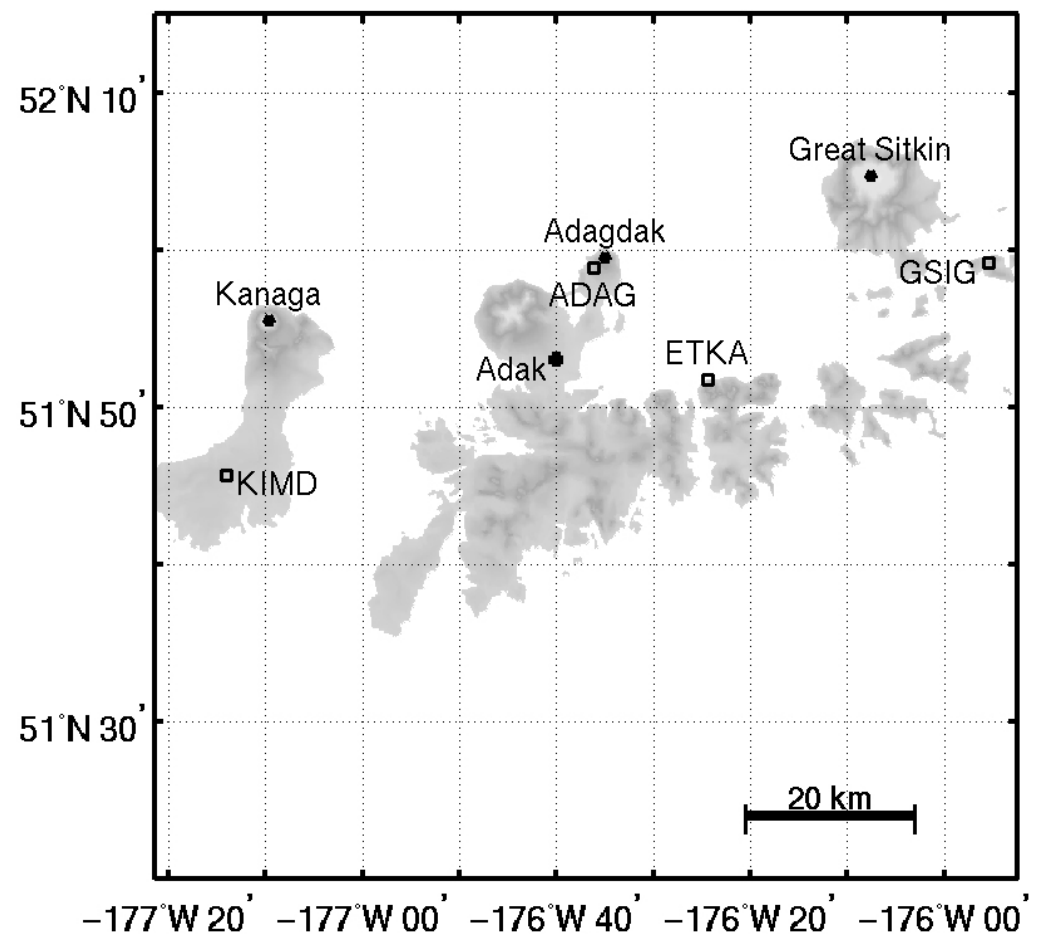

Figure C19. Regional AVO seismic stations around Adak Island.

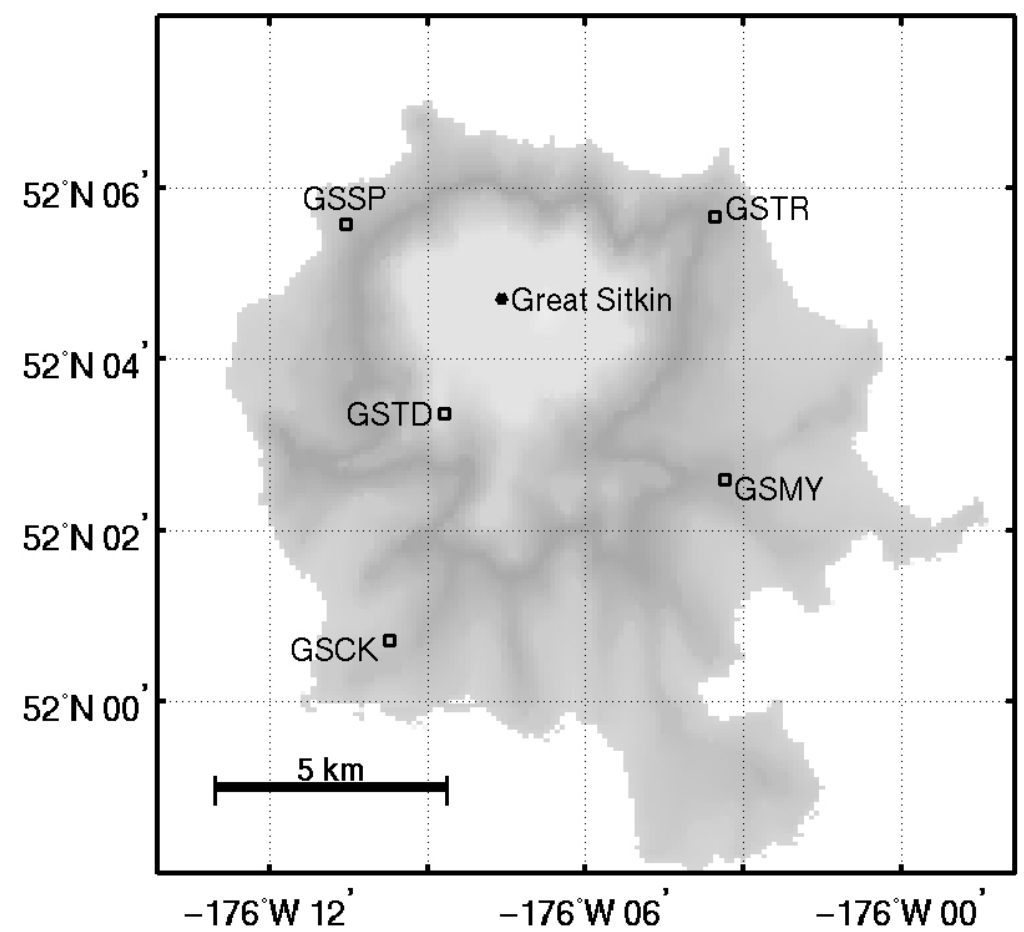

Figure C20. AVO seismic stations near Great Sitkin Volcano. 


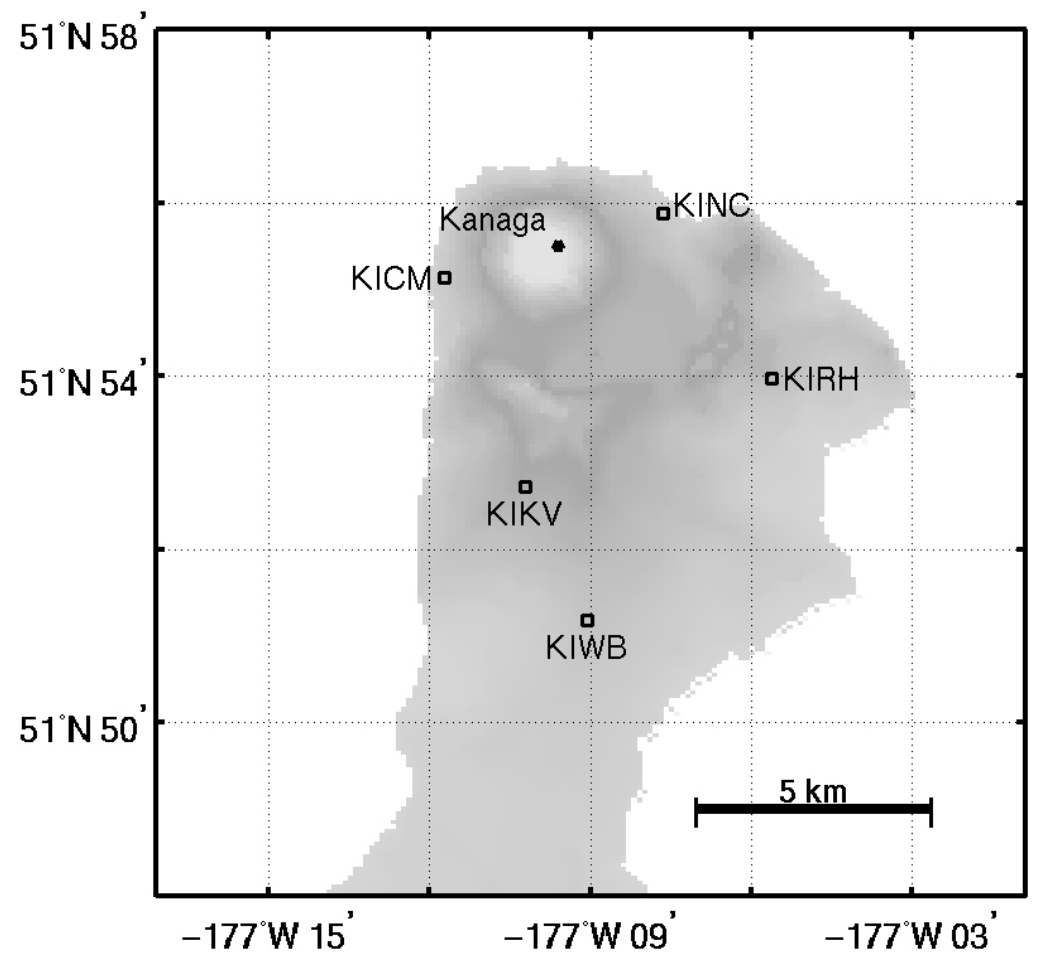

Figure C21. AVO seismic stations near Kanaga Volcano. 
Appendix D: Velocity models used in locating the earthquakes described in this report. Following the name of each velocity model is a list of monitored volcanoes for which the model is used. Depths are referenced to sea level, with negative values reflecting height above sea level.

\begin{tabular}{|c|c|c|c|c|c|}
\hline \multicolumn{6}{|c|}{ Cylindrical Model Parameters } \\
\hline Velocity Model & Latitude $\left({ }^{\circ} \mathrm{N}\right)$ & Longitude $\left({ }^{\circ} \mathrm{W}\right)$ & $\underline{\text { Radius (km) }}$ & Top $(\mathrm{km})$ & Bottom (km) \\
\hline Spurr & 61.60 & 152.40 & 20 & -3 & 50 \\
\hline Spurr & 61.47 & 152.33 & 20 & -3 & 50 \\
\hline Spurr & 61.33 & 152.25 & 20 & -3 & 50 \\
\hline Spurr & 61.17 & 152.35 & 20 & -3 & 50 \\
\hline Spurr & 61.00 & 152.45 & 20 & -3 & 50 \\
\hline Redoubt & 60.83 & 152.55 & 20 & -3 & 50 \\
\hline Redoubt & 60.66 & 152.66 & 20 & -3 & 50 \\
\hline Redoubt & 60.49 & 152.75 & 20 & -3 & 50 \\
\hline Redoubt & 60.34 & 152.86 & 20 & -3 & 50 \\
\hline Iliamna & 60.03 & 153.09 & 20 & -3 & 50 \\
\hline Augustine & 59.36 & 153.42 & 20 & -3 & 50 \\
\hline Katmai & 58.17 & 155.35 & 20 & -3 & 50 \\
\hline Katmai & 58.29 & 154.86 & 20 & -3 & 50 \\
\hline Katmai & 58.35 & 155.09 & 20 & -3 & 50 \\
\hline Katmai & 58.43 & 154.38 & 20 & -3 & 50 \\
\hline Cold Bay & 55.42 & 161.89 & 20 & -3 & 50 \\
\hline Cold Bay & 55.18 & 162.27 & 20 & -3 & 50 \\
\hline Cold Bay & 54.76 & 163.97 & 30 & -3 & 50 \\
\hline Cold Bay & 54.52 & 164.65 & 20 & -3 & 50 \\
\hline Akutan & 54.15 & 165.97 & 20 & -3 & 50 \\
\hline Andreanof & 52.08 & 176.13 & 20 & -3 & 50 \\
\hline Andreanof & 51.93 & 176.75 & 20 & -3 & 50 \\
\hline Andreanof & 51.92 & 177.17 & 20 & -3 & 50 \\
\hline
\end{tabular}

Regional Velocity Model (for all areas south of $62.5^{\circ} \mathrm{N}$ not covered by a volcano specific model): Aniakchak Crater, Makushin Volcano, Okmok Volcano, Mount Veniaminof, and Mount Wrangell (Fogleman and others, 1993).

\begin{tabular}{c} 
Layer number \\
\hline 1 \\
2 \\
3 \\
4 \\
5 \\
6 \\
7 \\
8 \\
9
\end{tabular}

\begin{tabular}{c}
$\mathrm{Vp}(\mathrm{km} / \mathrm{sec})$ \\
\hline 5.3 \\
5.6 \\
6.2 \\
6.9 \\
7.4 \\
7.7 \\
7.9 \\
8.1 \\
8.3
\end{tabular}

\begin{tabular}{c} 
Top of layer $(\mathrm{km})$ \\
\hline-3.0 \\
4.0 \\
10.0 \\
15.0 \\
20.0 \\
25.0 \\
33.0 \\
47.0 \\
65.0
\end{tabular}

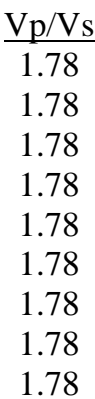

Akutan Velocity Model: Akutan Peak (Power and others, 1996).

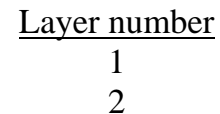

$\frac{\mathrm{Vp}(\mathrm{km} / \mathrm{sec})}{2.30+0.37 \mathrm{~km} / \mathrm{sec} \text { for each } \mathrm{km} \text { of depth }}$
6.30

Top of layer $(\mathrm{km})$
-3.0
7.0

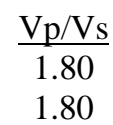


Andreanof Velocity model: Great Sitkin Volcano, Kanaga Volcano (Toth and Kisslinger, 1984).

\begin{tabular}{cccc} 
Layer number & Vp $(\mathrm{km} / \mathrm{sec})$ & Top of layer $(\mathrm{km})$ & Vp/Vs \\
\cline { 2 - 4 } 1 & 3.50 & -3.0 & 1.73 \\
2 & 3.88 & -2.8 & 1.73 \\
3 & 4.25 & -2.6 & 1.73 \\
4 & 4.62 & -2.4 & 1.73 \\
5 & 5.00 & -2.2 & 1.73 \\
6 & 5.50 & -2.0 & 1.73 \\
7 & 5.62 & -1.0 & 1.73 \\
8 & 5.74 & 0.0 & 1.73 \\
9 & 5.86 & 1.0 & 1.73 \\
10 & 5.98 & 2.0 & 1.73 \\
11 & 6.10 & 3.0 & 1.73 \\
12 & 6.60 & 4.0 & 1.73 \\
13 & 6.68 & 5.0 & 1.73 \\
14 & 6.80 & 8.0 & 1.73 \\
15 & 6.92 & 11.0 & 1.73 \\
16 & 7.04 & 14.0 & 1.73 \\
17 & 7.16 & 17.0 & 1.73 \\
18 & 7.28 & 20.0 & 1.73 \\
19 & 7.85 & 23.0 & 1.73 \\
20 & 8.05 & 37.0 & 1.73
\end{tabular}

Augustine Velocity Model: Augustine Volcano (Power, 1988).

\begin{tabular}{cccc} 
Layer number & Vp $(\mathrm{km} / \mathrm{sec})$ & Top of layer $(\mathrm{km})$ & Vp/Vs \\
\cline { 3 - 4 } & 2.3 & -3.0 & 1.80 \\
2 & 2.6 & -0.7 & 1.80 \\
3 & 3.4 & 0.0 & 1.80 \\
4 & 5.1 & 1.0 & 1.80 \\
5 & 6.3 & 9.0 & 1.78 \\
6 & 8.0 & 44.0 & 1.78
\end{tabular}

Cold Bay Velocity Model: Mount Dutton, Fisher Caldera, Isanotski Peaks, Pavlof Volcano, Shishaldin Volcano and Westdahl Peak (McNutt and Jacob, 1986).

\begin{tabular}{|c|c|c|c|}
\hline Layer number & $\underline{\mathrm{Vp}(\mathrm{km} / \mathrm{sec})}$ & Top of layer $(\mathrm{km})$ & $\underline{\mathrm{Vp} / \mathrm{Vs}}$ \\
\hline 1 & 3.05 & -3.00 & 1.78 \\
\hline 2 & 3.44 & 0.00 & 1.78 \\
\hline 3 & 5.56 & 1.79 & 1.78 \\
\hline 4 & 6.06 & 3.65 & 1.78 \\
\hline 5 & 6.72 & 10.18 & 1.78 \\
\hline 6 & 7.61 & 22.63 & 1.78 \\
\hline 7 & 7.90 & 38.51 & 1.78 \\
\hline
\end{tabular}

Iliamna Velocity model: Iliamna Volcano (Roman and others, 2001).

\begin{tabular}{cccc} 
Layer number & Vp $(\mathrm{km} / \mathrm{sec})$ & Top of layer $(\mathrm{km})$ & $\frac{\mathrm{Vp} / \mathrm{Vs}}{1.78}$ \\
\cline { 2 - 4 } 2 & 4.8 & -3.0 & 1.78 \\
3 & 6.1 & -1.6 & 1.78 \\
4 & 6.2 & 1.7 & 1.78 \\
5 & 6.3 & 2.9 & 1.78 \\
6 & 6.4 & 3.1 & 1.78
\end{tabular}


Katmai Velocity Model: Mount Griggs, Mount Katmai, Mount Mageik, Mount Martin, Novarupta, Snowy Mountain, and Trident Volcano (Jolly, 2000).

Layer number

1

2

3

4

5

6

7

8

9

10

11
$\mathrm{Vp}(\mathrm{km} / \mathrm{sec})$

5.0

5.3

5.6

5.9

6.1

6.9

7.4

7.7

7.9

8.1

8.3
Top of layer (km)

$-3.0$

0.0

2.0

4.0

6.0

15.0

20.0

25.0

33.0

47.0

65.0
$\mathrm{Vp} / \mathrm{Vs}$

1.78

1.78

1.78

1.78

1.78

1.78

1.78

1.78

1.78

1.78

1.78

Redoubt Velocity Model: Redoubt Volcano (Lahr and others, 1994) .

Layer number

1

2

3

4
$\underline{\mathrm{Vp}(\mathrm{km} / \mathrm{sec})}$

2.90

5.10

6.40

7.00
Top of layer $(\mathrm{km})$

$-3.0$

$-1.7$

1.5

17.0
$\underline{\mathrm{Vp} / \mathrm{Vs}}$

1.80

1.80

1.72

1.78

Spurr Velocity Model: Mount Spurr (Jolly and others, 1994).

Layer number

1

2

3

4
Vp $(\mathrm{km} / \mathrm{sec})$

5.1

5.5

6.3

7.2
Top of layer $(\mathrm{km})$

$-3.00$

$-2.00$

5.25

27.25
$\underline{\mathrm{Vp} / \mathrm{Vs}}$

1.81

1.81

1.74

1.78 


\section{Appendix E: Maps showing the location of the volcanic zones modeled using} cylinders.

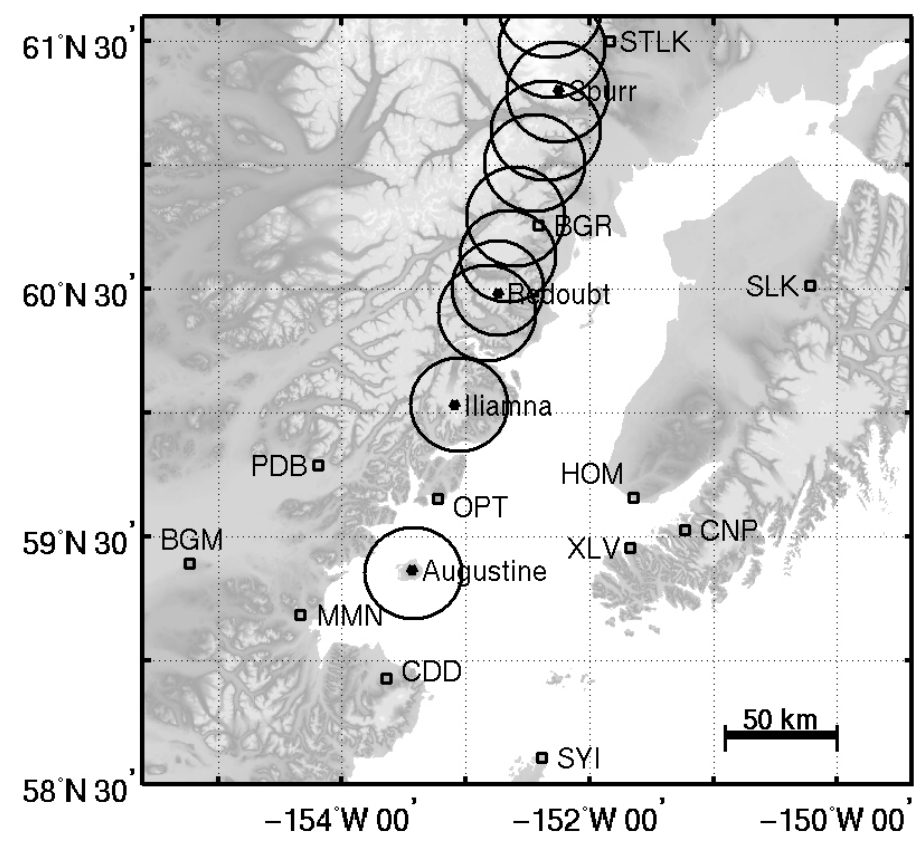

Map E1. Volcanic zones modeled using cylinders as an approximation for the volcanic seismic zones in Cook Inlet.

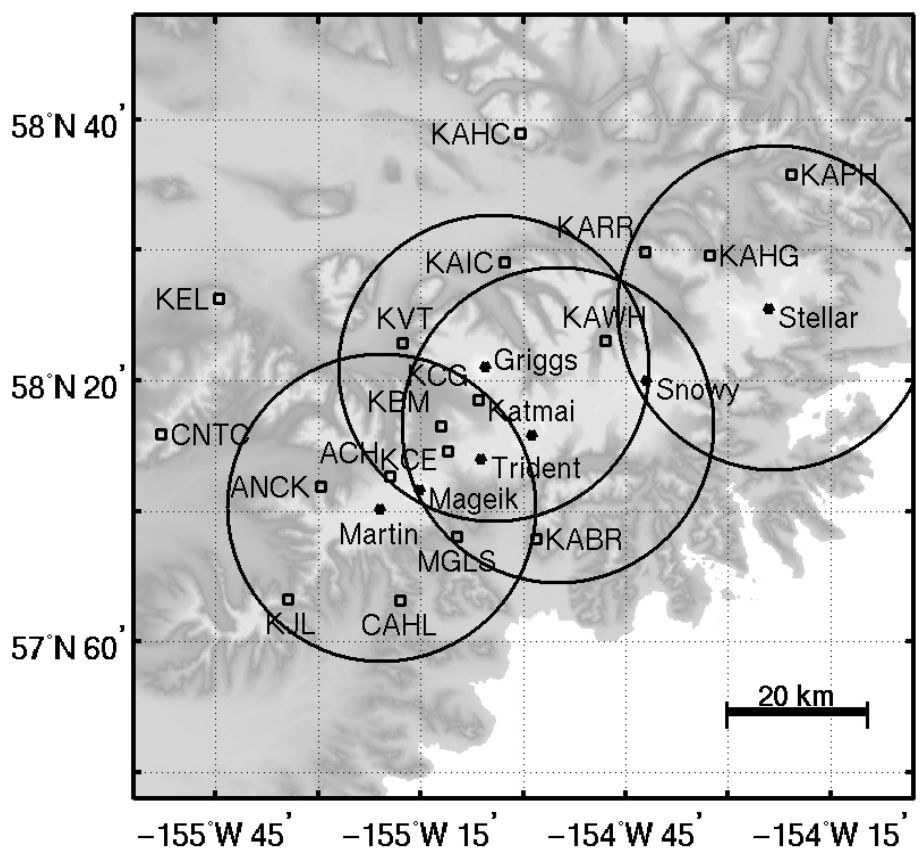

Map E2. Volcanic zone modeled using cylinders as an approximation for the volcanic seismic zone in the Katmai volcanic group. 


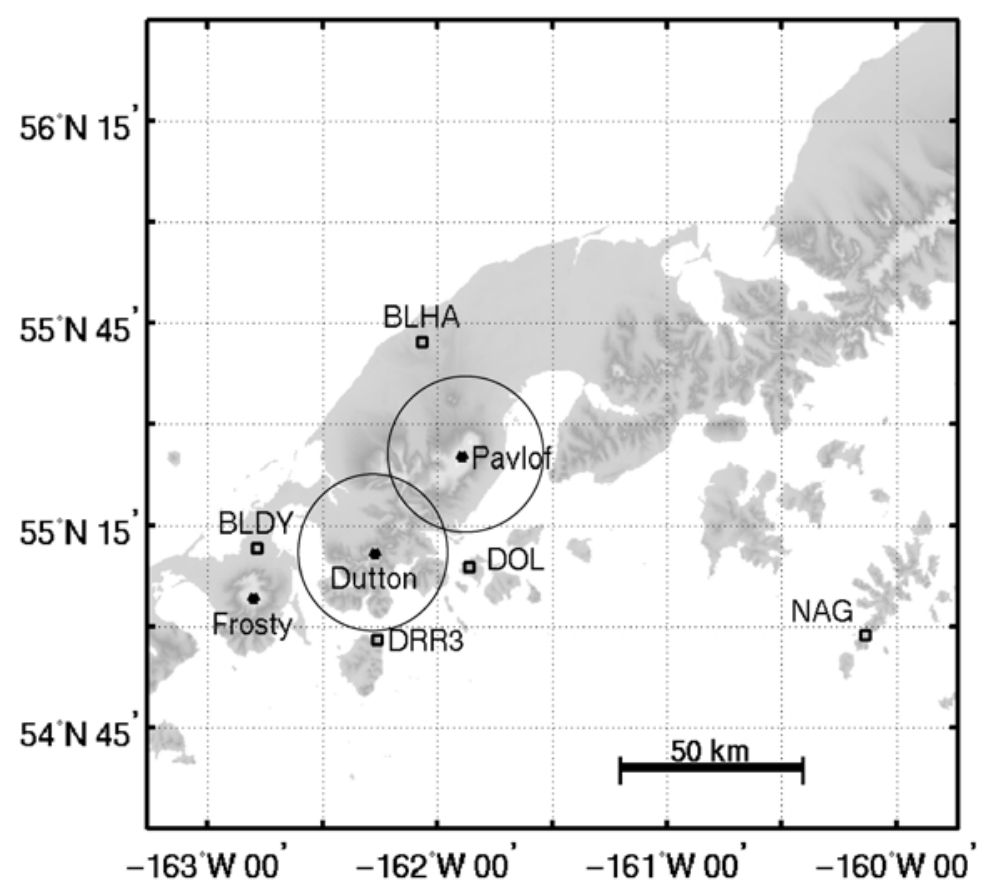

Map E3. Volcanic zones modeled using cylinders as an approximation for the volcanic seismic zones in the Pavlof/Dutton region.

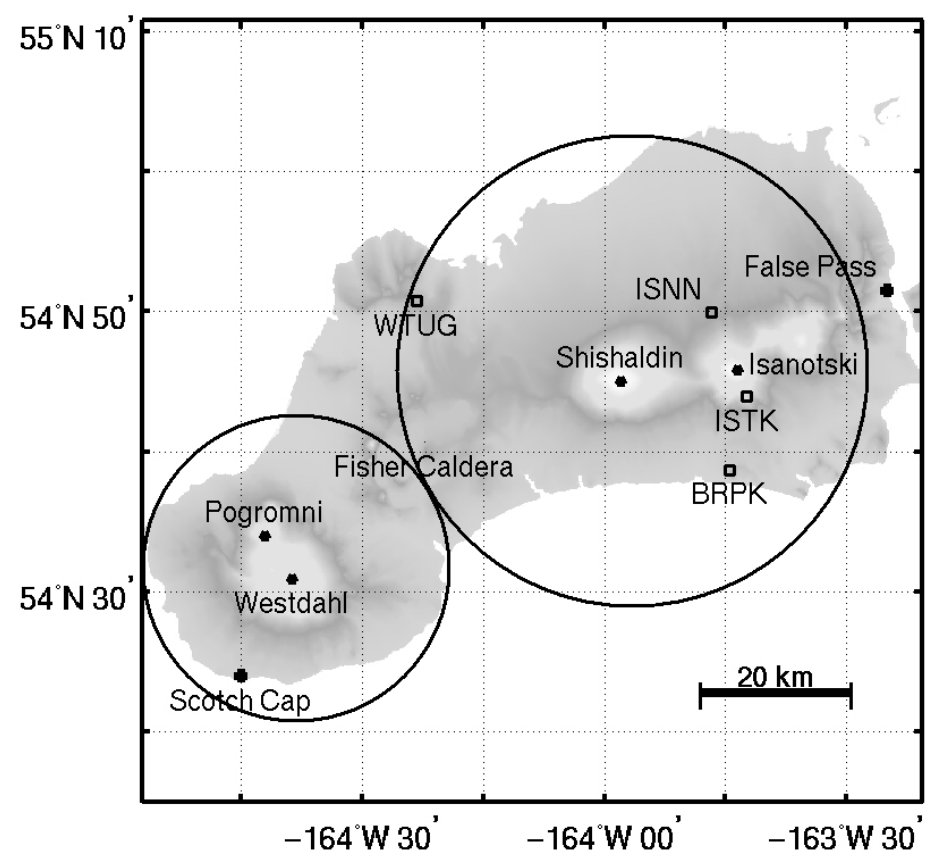

Map E4. Volcanic zones modeled using cylinders as an approximation for the volcanic seismic zones on Unimak Island 


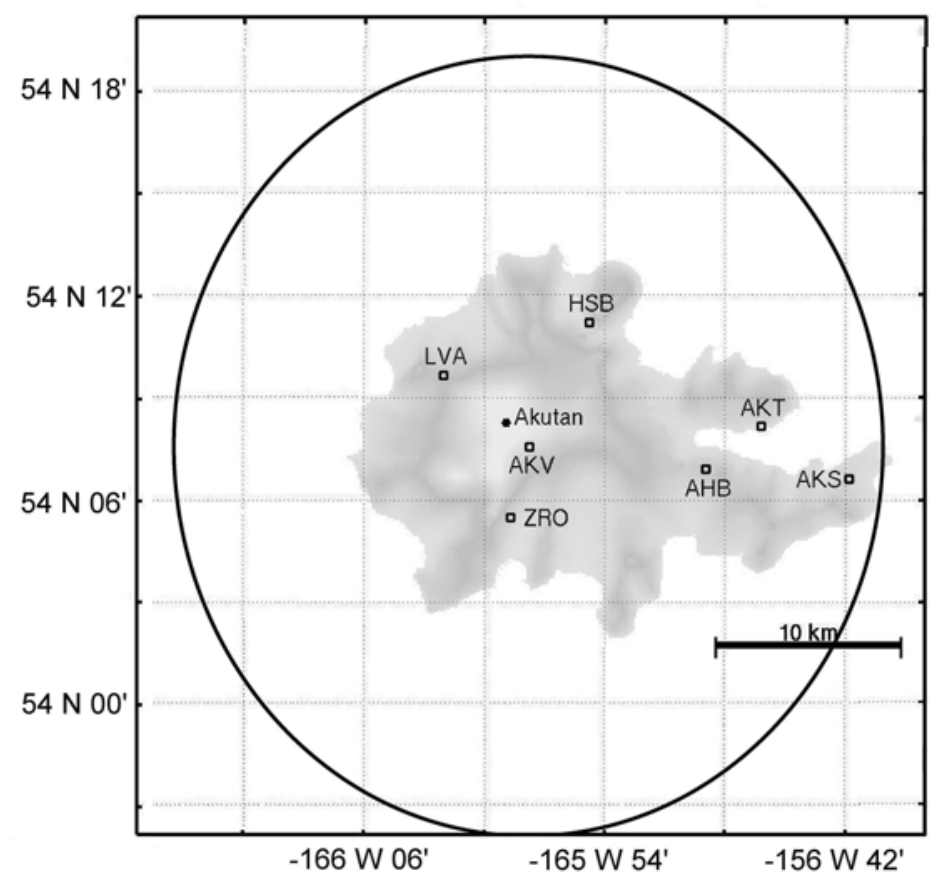

Map E5. Volcanic zone modeled using a cylinder as an approximation for the volcanic seismic zone on Akutan Island.

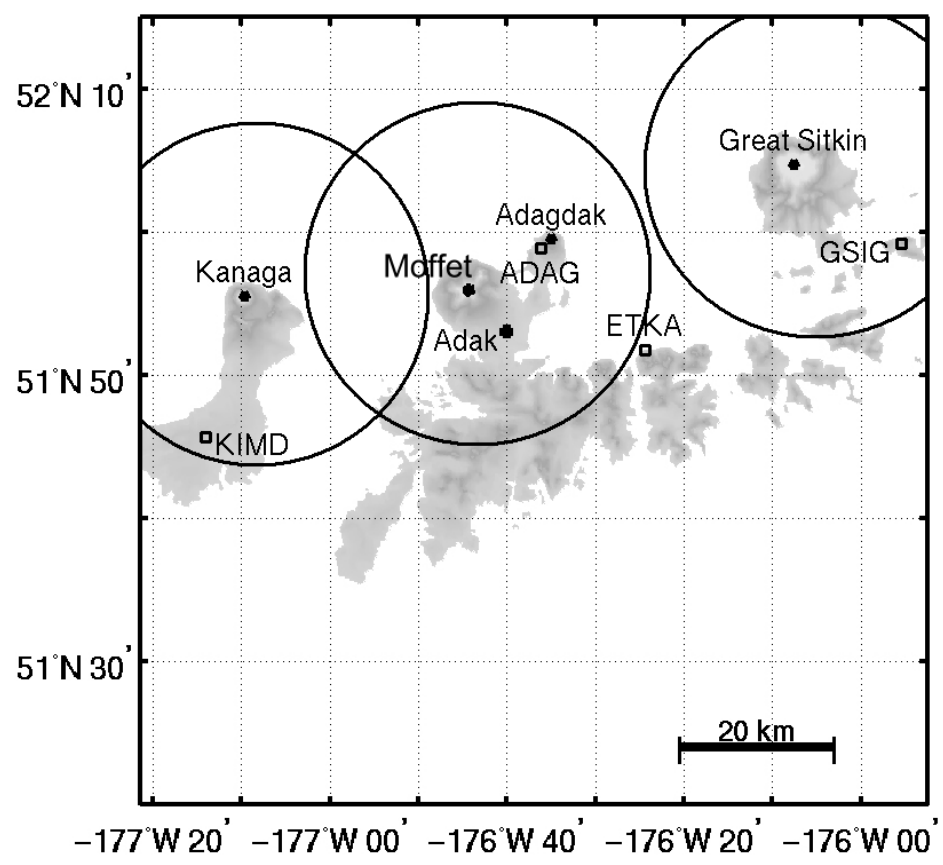

Map E6. Volcanic zones modeled using cylinders as an approximation for the volcanic seismic zone in the Great Sitkin/Kanaga Island region. 


\section{Appendix F: Station usage plots}

This appendix contains monthly plots showing station usage per day for each station in each sub-network operated by the AVO. These plots provide a measure of both an individual station's operational health and earthquake frequency of occurrence near a given volcano. It is noted that an absence of seismicity at a given sub-network might imply either a station outage or a lack of seismicity at that station. These plots are in a separate PDF file that is available with this report. Appendix F is 83 pages in length. A sample station use plot is shown below.

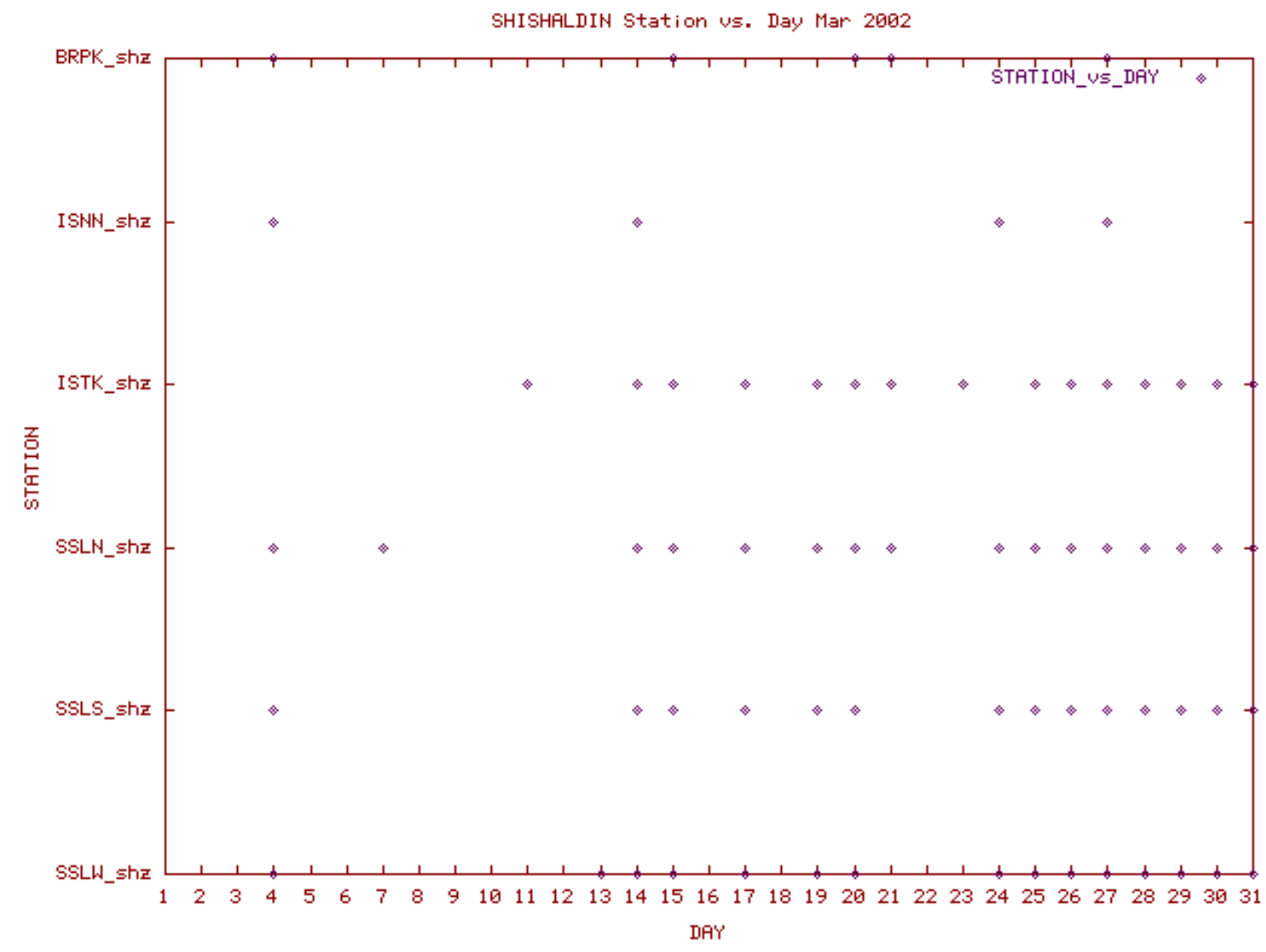

Station-use plot for the Shishaldin subnetwork show the stations that were used to located earthquakes in March 2001. The presence of a dot indicates the station was used to locate at least one earthquake by the AVO for the day it represents. 


\section{Appendix G: Selected AVO papers published in 2002}

Caplan-Auerbach, J., and S. R. McNutt, 2002, New insights into the 1999

eruptions of Shishaldin volcano based on acoustic data. Bulletin of Volcanology, DOI 10.1007/s00445-002-0267-5.

Dean, K., J. Dehn, S. McNutt, C. Neal, R. Moore, and D. Schneider, 2002, The 2001 Eruptions of Mt. Cleveland, Chuginadak Island, Alaska, Eos Transactions of the American Geophysical Union, v.83, p.243, 246-247.

Dixon, J.P, Stihler, S.D., Power, Tytgat, G., Estes, S., Moran, S.C., Paskievitch, J., McNutt, S.R., 2002, Catalog of Earthquake Hypocenters at Alaska Volcanoes: January 1, 2000-December 31, 2001: U.S. Geological Survey Open-file Report 02-342, 56p.

Lu, Z., Power, J.A., McConnell, V.S., Wicks, C., Dzurisin, D., 2002, Preeruptive inflation and surface interferometric coherence and characteristics revealed by satellite RADAR interferometry at Makushin Volcano, Alaska: 1993-2000: Journal of Geophysical Research, v. 107, DOI 10.1029/2001JB000970, p. ECV1-1-13.

Lu, Z., Wicks, C., Dzurisin, D., Power, J.A., Moran, S.C., Thatcher, W., 2002, Magmatic inflation at a dormant stratovolcano: 1996-98 activity at Mount Peulik Volcano, Alaska, revealed by satellite radar interferometry: Journal of Geophysical Research, v. 107, DOI 10.1029/2001JB000471, p. ETG4-1-13.

McNutt, S.R., Volcano Seismology, 2002, Chapter 25 of International Handbook of Earthquake and Engineering Seismology, Lee, W.H.K., H. Kanamori, and P.C. Jennings (eds.), v. 81A, IASPEI, Palo Alto, CA, p. 383-406.

Moran, S.C., Stihler, S.D., and Power, J.A., 2002, A tectonic earthquake sequence preceding the April-May 1999 eruption of Shishaldin Volcano, Alaska: Bulletin of Volcanology, v. 64, DOI 10.1007/s00445-002-0226-1, p. 520-524.

Nye, C.J., Keith, T.E.C., Eichelberger, J.C., Miller, T.P., McNutt, S.R., Moran, S.C., Schneider, D.J., Dehn, J., and Schaefer, J.R., 2002, The 1999 eruptions of Shishaldin Volcano, Alaska: remote monitoring using multiple data streams: Bulletin of Volcanology, v. 64, DOI 10.1007/s00445-002-0225-2, p. 507-519.

Power, J.A., Jolly, A.D., Nye, C.J., Harbin, M.L., 2002, A conceptual model of the Mount Spurr magmatic system from seismic and geochemical observations of the 1992 Crater Peak eruption sequence. Bulletin of Volcanology, v. 64, DOI 10.1007/s00445002-0201-x, p. 206-218.

Thompson, G., S.R. McNutt, and G. Tytgat, 2002, Three Distinct Regimes of Volcanic Tremor Associated with Eruptions of Shishaldin Volcano, Alaska, April 1999. Bulletin of Volcanology, v. 64, DOI 10.1007/s00445-002-0228-z, p. 535547. 